\title{
Filicopsida from the lower Westphalian (Middle Pennsylvanian) of Nova Scotia and New Brunswick, Maritime Provinces, Canada
}

\author{
CARMEn ÁlvareZ-VÁzQueZ \\ Centro Paleobotánico, Real Jardín Botánico de Córdoba, Avenida de Linneo, s/n, 14004 Córdoba, Spain \\ <paleo.calvarez@jardinbotanicodecordoba.com> \\ In memoriam: Robert H. Wagner (1927-2018)
}

Date received: 04 June 2018 Date accepted: 02 January 2019

\begin{abstract}
This paper presents a taxonomic revision of filicopsid taxa from the lower to middle Westphalian strata of Nova Scotia and New Brunswick, Maritime Provinces of Canada. Most of the material represents sporadic historical collecting by Geological Survey of Canada (GSC) personnel, and specimens are in the GSC collections in Ottawa. Additional specimens are in the New Brunswick Museum at Saint John, the Fundy Geological Museum at Parrsboro, and the Joggins Fossil Institute at Joggins. Two specimens from outside Canada clarify specific characteristics. The revision involved the detailed examination of 20 adpression (mainly impression) taxa, of which one, Germera brousmicheae, is new. Detailed synonymy lists, with particular focus on records from Canada and the USA, facilitate a refinement of the stratigraphic and geographic distribution of these species. Most of the taxa from the Maritimes are the same as those from other parts of the paleoequatorial belt of Pennsylvanian times. The Maritimes record of filicopsid taxa closely resembles the filicopsid floras of western Europe, most notably the British Isles.
\end{abstract}

\section{RÉSUMÉ}

Cet article présente une révision taxonomique des taxons de Filicopsida provenant de la strate westphalienne moyenne à inférieure de la Nouvelle-Écosse et du Nouveau-Brunswick, des provinces maritimes du Canada. La plupart des documents décrivent la collecte de données historiques sporadiques effectuée par les membres du personnel de la Commission géologique du Canada (CGC), et des spécimens se trouvent dans les collections de la CGC à Ottawa. D’autres spécimens sont exposés au Musée du Nouveau-Brunswick de Saint John, au Fundy Geological Museum de Parrsboro, et au Joggins Fossil Institute de Joggins. Deux spécimens prélevés à l'extérieur du Canada apportent des précisions sur des caractéristiques particulières. La révision a nécessité l'examen de 20 taxons en adpression (principalement en impression), parmi lesquels un taxon, Germera brousmicheae, est nouveau. Des listes détaillées de synonymes, mettant un accent particulier sur les registres provenant du Canada et des États-Unis, facilitent le raffinement de la répartition géographique et stratigraphique de ces espèces. La plupart des taxons des Maritimes sont les mêmes que ceux des autres parties de la ceinture paléoéquatoriale du Pennsylvanien. Les registres de taxons de Filicopsida provenant des Maritimes ressemblent fortement aux flores de la classe des Filicopsida de l'Europe de l'Ouest, plus particulièrement des îles Britanniques.

[Traduit par la redaction]

\section{INTRODUCTION}

This study is the eighth part of a taxonomic revision of the upper Namurian to middle Westphalian floras of the Maritime Provinces of Canada. The revision was embarked upon in 2000 on the initiative of the late John Utting, then of the Geological Survey of Canada. The reporting of results began with a series of short papers (Wagner 2001a, 2005a, b, 2008; Wagner and Álvarez-Vázquez 2008), and continued with more extensive contributions on lycopsids (ÁlvarezVázquez and Wagner 2014) and the sphenopsid genera $A n$ nularia and Asterophyllites (Álvarez-Vázquez and Wagner 2017). (All names of taxa at generic and lower rank cited herein are listed with full authorship in the Appendix).

The floral remains dealt with in this study are preserved as adpressions (mainly impressions). Most of the material recorded here corresponds to that recorded by Walter A. Bell in the early part of the twentieth century (Bell 1944, 
1966), with specimens reposited in the collections of the Geological Survey of Canada, Ottawa. Also studied were specimens from the New Brunswick Museum at Saint John, the Fundy Geological Museum at Parrsboro, Nova Scotia, and the Donald Reid collection in the Joggins Fossil Institute, Joggins, Nova Scotia.

Although Bell (1944) published a very comprehensive account, his descriptions were brief and illustrations, although numerous and at natural size, do not always provide the necessary detail for an incontrovertible identification. The paper by Bell (1966) is more useful because the specimens illustrated were selected for quality. Much more information has become available on late Namurian to middle Westphalian plant macrofossils in recent decades, making Bell's work of seven decades ago in need of revision.

\section{REPOSITORY OF SPECIMENS, LOCALITY AND CATALOGUE NUMBERS}

Most of the specimens reviewed in the present paper are in the collections of the Geological Survey of Canada, Ottawa (catalogue numbers preceded by "GSC"). For more complete information about the localities the reader is referred to Bell (1938, p. 108-115; 1944, p. 111-118; 1962, p. 63-64). Additional material from the collections of the New Brunswick Museum at Saint John has catalogue numbers preceded by "NBMG". Moreover, six specimens from the Fundy Geological Museum, Parrsboro, Nova Scotia ("FGM") have been studied, as well as four from the Donald Reid Collection ("DRC"), Joggins Fossil Institute, Joggins, Nova Scotia.

\section{SYSTEMATICS}

As in our previous revisions of lycopsids (ÁlvarezVázquez and Wagner 2014) and Annularia and Asterophyllites (Álvarez-Vázquez and Wagner 2017), selective lists of synonyms are provided with the emphasis on published records from Canada and the USA. Only the most significant records from outside Canadian and the USA and/or specimens in the possession of the present author are cited, as well as synonyms accepted by the present author. The reader is referred to the Fossilium Catalogus (Plantae) for more complete (up to a certain date), but uncritical records.

Annotations in the synonymy lists are as follows: ${ }^{*}=$ protologue; $\$=$ first publication of currently accepted combination; $\mathrm{T}=$ other illustrations of the holotype; ? = references to doubtful specimens due to poor illustration or preservation; $\mathrm{p}=$ pars - only part of the specimens published belong to the species; $\mathrm{v}=$ vide - the author has seen the specimen(s); $\mathrm{k}=$ reference includes cuticular evidence; acc. $=$ according.

Descriptions, comparisons and remarks on published and revised specimens are given, as well as the stratigraphic and geographic distribution of taxa and their occurrences in Canada and the USA. Stratigraphic attributions are in accordance with the western European regional chronostratigraphic scheme of the Pennsylvanian Subsystem, since this is the most relevant to fossil plant records.

\section{Class Filicopsida \\ Order Crossothecales Danzé 1956 \\ Family Crossothecaceae Danzé 1956}

Genus Crossotheca Zeiller 1883

1883 Crossotheca Zeiller, p. 180 (August).

1883 Sorotheca Stur, p. 175 [807] (December).

1956 Crossotheca Zeiller; Danzé, p. 55-57, 135-139.

1982 Crossotheca Zeiller; Brousmiche, p. 686-688.

1983 Crossotheca Zeiller; Brousmiche, p. 120-122.

1986 Crossotheca Zeiller; Brousmiche, p. 233-234.

Type. Crossotheca crepinii Zeiller 1883.

Remarks. Pedunculate eusporangiate synangial fertile structures that are of very variable appearance depending on the degree of maturity: they may be globular, spherical or elongate. Individual lamina consists of a thick, horizontal, narrow part and a large folded part with segments that protect the sporangia; these are long and inserted in small groups of four or five terminal to veins. Vegetative pinnules sphenopteroid or pecopteroid.

\section{Crossotheca crepinii Zeiller 1883}

(Figs. 1a-b, d)

* 1883 Crossotheca Crepini Zeiller, p. 181, pl. IX, figs. 1-9.

T 1886-88 Sphenopteris (Crossotheca) Crepini Zeiller, p. 112-115, pl. XIII, figs. 1-1D (lectotype as designated by Brousmiche 1983), figs. 2-3A.

* 1886-88 Sphenopteris (Crossotheca) Boulayi Zeiller, p. 115-117, pl. IV, figs. 4-4C (acc. to Brousmiche 1983).

1938 Crossotheca boulayi Zeiller; Bell, p. 47, pl. XXXVI, figs. 1-4 (acc. to Brousmiche 1982).

1938 Corynepteris winslovii White; Bell, p. 39, pl. XXV, figs. 1-4.

* 1938 Sphenopteris aculeata Bell, p. 29, pl. XI, fig. 5; pl. XII, fig. 1 (although difficult to judge from the illustration, Bell's description suggests that this species falls within the morphological variation of Crossotheca crepinii. Additional specimens figured by Bell in 1966 from the same area in the Sydney coalfield confirm this impression).

* v 1944 Sphenopteris philipensis Bell, p. 64-65, pl. VIII, fig. 2; pl. IX (partly refigured here as Fig. 1a); pl. X, figs. 2, 4 (fragmentary); pl. XII, fig. 3 (Fig. 1d herein).

T 1956 Crossotheca Crepini Zeiller; Danzé, p. 139-146, pl. I, figs. 1-5b; pl. II, fig. 1 (same as Zeiller 1886, pl. XIII, fig. 1), fig. 2 (same as Zeiller 1883, pl. IX, fig. 1), figs. 3-3a; pl. III, figs. 

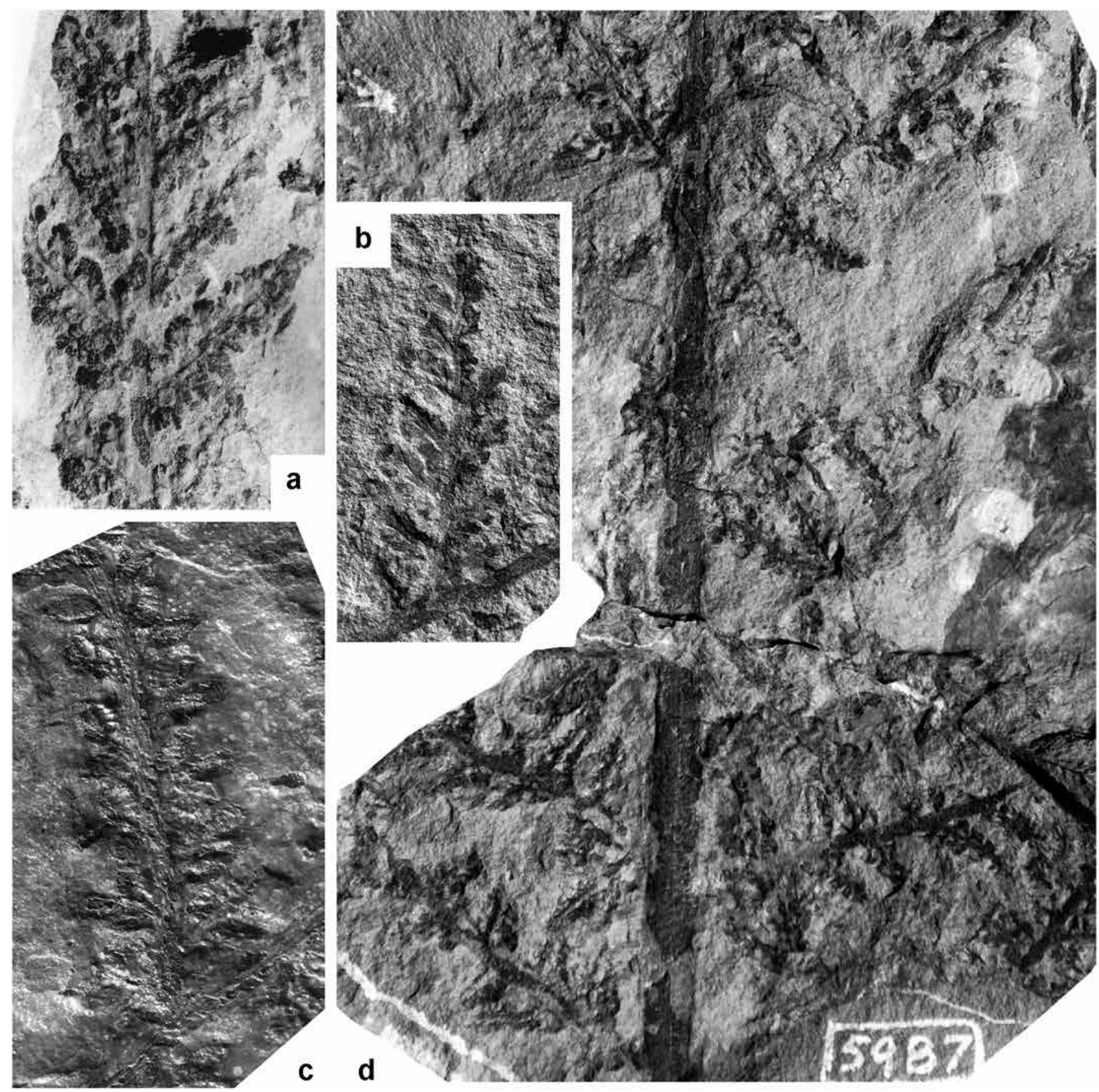

Figure 1. (a) Crossotheca crepinii ( $\times 3)$. GSC 5962. Part of the fertile specimen previously figured by Bell (1944, pl. VIII, fig. 2 and pl. IX) as Sphenopteris philipensis. Origin: East Branch River Philip, Oxford area, above Collingwood corner (locality 854), Nova Scotia. (b) Crossotheca crepinii ( $\times 6)$. Detail of last order pinna. Origin: East Branch River Philip, Oxford area (locality 860), Nova Scotia. (c) Crossotheca compacta (×6). GSC 1125. Counterpart of the holotype (Bell 1938, pl. XXXVII, fig. 1) showing a fertile pinna fragment with every pinnule covered abaxially by oval or cylindrical (depending on the degree of maturity), closed sporangium, attached by a short pedicel, and bearing elongate sporangia on the lower surface. Origin: shore east of Schooner Pond Cove; roof of Ross (Emery) seam, Sydney Basin (locality 518), Nova Scotia. (d) Crossotheca crepinii ( $\times 2$ ). GSC 5987 (lower part) and GSC 5989 (upper part) of the holotype of Sphenopteris philipensis. Partially figured by Bell (1944, pl. XII, fig. 3). Origin: East Branch River Philip, Oxford area (locality 860), Nova Scotia. Repository: Geological Survey of Canada, Ottawa. 
1-1a, fig. 2 (same as Corsin 1932, pl. 30, fig. 2), figs. 3-5a; pl. IV, figs. 1-2; pl. V, figs. 1-4b; text-figs. 2a-d.

1956 Crossotheca Boulayi Zeiller; Danzé, p. 151157, pls VII, figs. 1-1d; pl. VIII, figs. 1-6a; pl. IX, figs. 1-2a; pl. X, figs. 1-4a; text-figs. 4a-d.

1956 Crossotheca Bourozi Danzé, p. 157-160, pls XI, figs. 1-6a; pl. XII, figs. 1-4b; pl. XIII, figs. 1-2c; pl. XIV, figs. 1-3; pl. XV, figs. 1-2a; text-figs. 5a-c (acc. to Brousmiche 1983).

1966 Sphenopteris (Crossotheca) boulayi Zeiller; Bell, p. 42, pl. XX, figs. 7-8.

1966 Sphenopteris aculeata Bell, p. 52, pl. XXV, figs. 2-3.

? $1981 \quad$ Sphenopteris (?) schatzlarensis (Stur) Zeiller; DiMichele and Dolph, p. 5, pl. 1, fig. 7 (difficult to judge from the illustration).

T 1982 Crossotheca crepinii Zeiller; Brousmiche, p. 688-691 (including synonymy), pl. 1, fig. 1 (same as Danzé 1956, pl. VII, figs. 1a-1d), figs. 2-2a (same as Danzé 1956, pl. VIII, figs. 3-3a), figs. 3-3a (same as Zeiller 1886, pl. IV, fig. 4), figs. 4-4a (same as Danzé 1956, pl. I, fig. 1), fig. 5 (same as Zeiller 1886, pl. XIII, figs. 1-1b), figs. 6-6a (same as Danzé 1956, pl. I, fig. 4); pl. 2, figs. 1-1b (same as Danzé 1956, pl. XIII, figs. 2-2c), figs. 2-4a, figs. 5-5a (same as Danzé 1956, pl. XIV, fig. 3), figs. 6-6a; pl. 3, fig. 1 (same as Danzé 1956, pl. V, figs. 4-4b); pl. 2, fig. 2 (same as Danzé 1956, pl. IV, figs. 1-1a), fig. 3 (same as Danzé 1956, pl. IX, figs. 2-2a), fig. 4 (same as Zeiller 1886, pl. IV, fig. 4), figs. $5-7$; pl. 4 , figs. $1-2 b$, figs. 3-8 (spores); pl. 5 , figs. 1-8 (spores); textfigs. 1A-3.

T 1983 Crossotheca crepinii Zeiller; Brousmiche, p. 122-126 (including synonymy), pl. 24, figs. 1-1a (part of the lectotype), figs. 2-2a (same as Zeiller 1886, pl. IV, fig. 4), figs. 3-3a, figs. 4-4a (same as Danzé 1956, pl. VIII, figs. 1-1a), figs. 5-8a; pl. 25, figs. 1-4a, 5 (enlargement of Zeiller 1886, pl. IV, fig. 4), figs. 6-8a; pl. 26, figs. 1-1g; text-figs. 30A-J3.

Description. Frond at least tripinnate. Antepenultimate rachis straight, flat, ca. $4 \mathrm{~mm}$ wide, finely striate longitudinally and with faint transverse markings. Penultimate pinnae well-spaced, alternate, always incomplete but apparently lanceolate. Dimensions: at least $60 \mathrm{~mm}$ long and $30 \mathrm{~mm}$ broad at base. Penultimate rachis inserted at $45-50^{\circ}$, straight, flat, ca. $1 \mathrm{~mm}$ wide, with fine longitudinal striations and broad transverse markings (not always visible). Last order pinnae closely spaced but not touching laterally, lanceolate, with a rounded apical pinnule; up to $16 \mathrm{~mm}$ long and $7 \mathrm{~mm}$ broad. Last order rachis inserted at $70-80^{\circ}$, straight, flat, ca. $0.6 \mathrm{~mm}$ wide. Pinnules alternate and slightly oblique to the rachis; small, with a stout footstalk, and apparently linked by a narrow strip of lamina alongside the rachis; pinnules deeply dissected into three to nine rounded to spatulate lobes. Nervation hardly visible due to the thick convex lamina and the coarseness of the siltstone on which the pinnules are imprinted. When evident, the midrib is relatively wide, slightly decurrent, forking once or twice at a wide angle.

Remarks. Bell (1944) figured one small fragment and two larger ones, the latter consisting of poorly preserved vegetative remains of a species that he regarded as new, i.e. Sphenopteris philipensis. Bell's specimens are impressions on a siltstone that emphasizes the convex nature of pinnule lobes. The relative coarseness of sediment and the vaulted lamina combine to show the exact outline of pinnules only occasionally. Unfortunately the specimens were varnished, thus making detailed observation as well as photography difficult. No additional remains of Sphenopteris philipensis have been recorded since its introduction by Bell (1944).

Bell $(1944$, p. 65) noted the resemblance of Sphenopteris philipensis to Crossotheca kidstonii and Sphenopteris hoeninghausii (= Lyginopteris hoeninghausii). The latter species has often been confused with Crossotheca, and Jongmans (in Crookall 1930, p. 635) regarded Crossotheca kidstonii as synonymous with Crossotheca schatzlarensis, a species that Brousmiche (1982, p. 690) considered synonymous with Crossotheca crepinii. The exhaustive illustration of Crossotheca kidstonii by Jongmans's (1951) and the revision of Crossotheca crepinii by Brousmiche $(1982,1983)$ make clear that Crossotheca is morphologically highly variable. This has not always been considered when small fragments were assigned to a species. Bell (1944) did not compare Sphenopteris philipensis with Crossotheca crepinii, but the short last order pinnae with small, simple to trilobate pinnules with a strongly convex lamina fit perfectly with the latter species.

I also include in Crossotheca crepinii specimens from the Sydney Basin figured as Sphenopteris aculeata by Bell (1938, pl. XI, fig. 5; pl. XII, fig. 1; 1966, pl. XXV, figs. 2-3). Only one fragmentary specimen (the holotype) was figured and described by Bell (1938). It consists of a rachis of the antepenultimate order on which a few incomplete pinnae are inserted. Bell's specimen shows sphenopteroid to pecopteroid, simple as well as lobate pinnules, with three to five rounded lobes, and veins that are deeply immersed within the lamina. Although this specimen is difficult to evaluate from the illustration and I have not been able to reexamine it directly, its general aspect and Bell's description suggest that it falls within the morphological variation of Crossotheca crepinii. The additional specimens of Sphenopteris aculeata figured by Bell (1966, pl. XXV, figs. 2-3) are better preserved and quite characteristic of Crossotheca crepinii. As with Sphenopteris philipensis, no further records of Sphenopteris aculeata exist.

Comparisons. Vegetative pinnules of Crossotheca schatzlarensis show one to three pairs of narrower, more widely extended lobes. The pinnules of Lyginopteris hoeninghausii are also highly variable, from orbicular to obtusely subtriangular, 
and each has a markedly convex lamina. However, its pinnules are spatulate and truncate, and the broad rachises are always punctate. Eusphenopteris pulchrior, a small-pinnuled pteridosperm, is also superficially similar to Crossotheca crepinii, but is characterized by shorter, more commonly trilobate, slightly larger pinnules.

Stratigraphic and geographic distribution. Although widespread, Crossotheca crepinii is an uncommon species. Brousmiche (1982) records it as a characteristic element of lower to middle Westphalian C (Bolsovian) floras. Its total range is from upper Westphalian B (Duckmantian) to the highest Westphalian D (Asturian).

Occurrence in the Maritime Provinces, Canada. CumberLAND BASIN (Nova Scotia): Bell (1944): locality 854 (GSC 5962 - paratype of Sphenopteris philipensis); locality 860 (GSC 5595 - fragmentary + GSC 5856 + GSC 5987 holotype + GSC 5989; the latter two specimens are figured herein as a single reconstructed fragment - see Fig. 1d) + GSC 5988 + GSC 5990 - paratypes of Sphenopteris philipensis); locality 752 (GSC 1659 + GSC 2897 - both figured as Corynepteris winslovii by Bell 1938) + GSC $2103+$ GSC 2111 + GSC 2113 + GSC 2114 - all figured as Crossotheca boulayi). Bell (1966): locality 752 (GSC 15048 - figured as Sphenopteris (Crossotheca) boulayi); locality 1314 (GSC 15042 - figured as Sphenopteris aculeata).

\section{Crossotheca compacta Bell 1938}

(Fig. 1c)

Remarks. For the sake of completeness, I illustrate part of an immature fertile specimen (Fig. 1c) from the Sydney Basin that is the counterpart of the holotype of Crossotheca compacta Bell (1938, pl. XXXVII, fig. 1). Crossotheca compacta is a species of doubtful utility since immature (closed) fertile remains are difficult to separate at species level. This specimen is identified as $n^{\circ} 1125$ in the GSC collections.

Order Urnatopteridales Danzé 1956

Family Urnatopteridaceae Danzé 1956

Genus Zeilleria Kidston 1884

p 1877 Calymmotheca Stur, p. 255.

1883 Calymmatotheca Zeiller, p. 182 (corrected spelling).

1884 Zeilleria Kidston, p. 590-591.

1924 Zeilleria Kidston, p. 427-429.

1956 Zeilleria Kidston; Danzé, p. 73-75, 241-245.

1960 Bertrandia Dalinval, p. 186 (acc. to Brousmiche and Laveine 1982).

1971 Zeilleria Kidston; Thomas and Crampton, p. 283.

1983 Zeilleria Kidston; Brousmiche, p. 197-199.
Remarks. The genus Zeilleria was instituted by Kidston (1884) for the fertile parts of three species previously described: Sphenopteris delicatula, Calymmotheca avoldensis and Calymmotheca frenzlii. It is characterized by globular to oval synangia that are situated at the end of lateral veins; these split into four or five sporangia at maturity. Stur's Calymmotheca refers to cupules, not microsporangiate structures. Kidston (1884) initially believed Zeilleria to be a fern, but later referred it to the pteridosperms as a result of a mistaken interpretation as seed-bearing cupules (Kidston 1911, 1924).

Dalinval (1960) introduced the generic name Bertrandia to accommodate Zeilleria avoldensis, the one species with pecopteroid pinnules; all the other species of Zeilleria possess sphenopteroid pinnules. Bertrandia has been treated as a synonym of Zeilleria by subsequent authors (e.g., Brousmiche and Laveine 1982).

\section{Zeilleria avoldensis (Stur 1883) Kidston 1884}

(Figs. 2a-e)

* ? 1868 Sphenopteris pilosa Dawson, p. 534, 548, 552, fig. 192F (diagrammatic drawing).

? 1871 Callipteris pilosa Dawson, p. 51, pl. XVI, fig. 189-189b (diagrammatic drawings).

*? 1871 Pecopteris (Cyathites?) densifolia Dawson, p. 56, pl. XVII, figs. 195-196 (drawings - included by Stopes 1914 in Pecopteris miltonii, and by Bell 1944 in Pecopteris pilosa).

* 1883 Calymmotheca Avoldensis Stur, p. 171 [803], Figs. 37a-b.

$\$ 1884$ Zeilleria avoldensis (Stur) Kidston, p. 591.

1885 Calymmotheca Avoldensis Stur, p. 251-255, Taf. XXXVII, fig. 1; text-figs. 41a-b.

p 1914 Pecopteris Miltoni (Artis) Brongniart; Stopes, p. 41-44, pl. VII, fig. 14 (photograph of Callipteris pilosa Dawson 1871, pl. XVI, fig. 189), fig. 15, fig. 16 (same as Dawson 1871, pl. XVII, fig. 195); text-figs. 5-6 (drawings); non pl. VII, fig. 17 (same as Dawson 1871, pl. XVII, fig. 196 - indeterminable).

1924 Zeilleria Avoldensis (Stur) Kidston; Kidston, p. 432-436, pl. XCVIII, figs. 1-2, figs. 3-6 (spores), fig. 8; pl. XCIX, figs. 1-2b, fig. 8 .

1927 Zeilleria avoldensis (Stur) Kidston; Corsin, p. 28-35, pl. I, figs. 1-7; pl. II, figs. 2, 5-6.

1928 Zeilleria avoldensis (Stur) Kidston; Jongmans, p. 21, pl. 14, figs. 3-4.

? 1938 Zeilleria avoldensis (Stur) Kidston; Bell, p. 35, pl. XXII, fig. 5 (difficult to judge from the illustration).

1938 Pecopteris clarkii Lesquereux; Bell, p. 82, pl. LXXXIII, fig. 3; pl. LXXXIV, fig. 1.

v p 1944 Pecopteris pilosa (Dawson) Bell, p. 85-86, pl. XIII, figs. 1, 5; pl. XXXIX, figs. 1-4; pl. XL, fig. 2, figs. 3-4 (herein Fig. 2d), fig. 5; pl. XLI, figs. 1, 4; pl. XLII, figs. 1, 6 (partially refigured herein as Fig. 2e), fig. 3; pl. XLIII; pl. XLIV (?-

Type. Zeilleria delicatula Kidston 1884. 

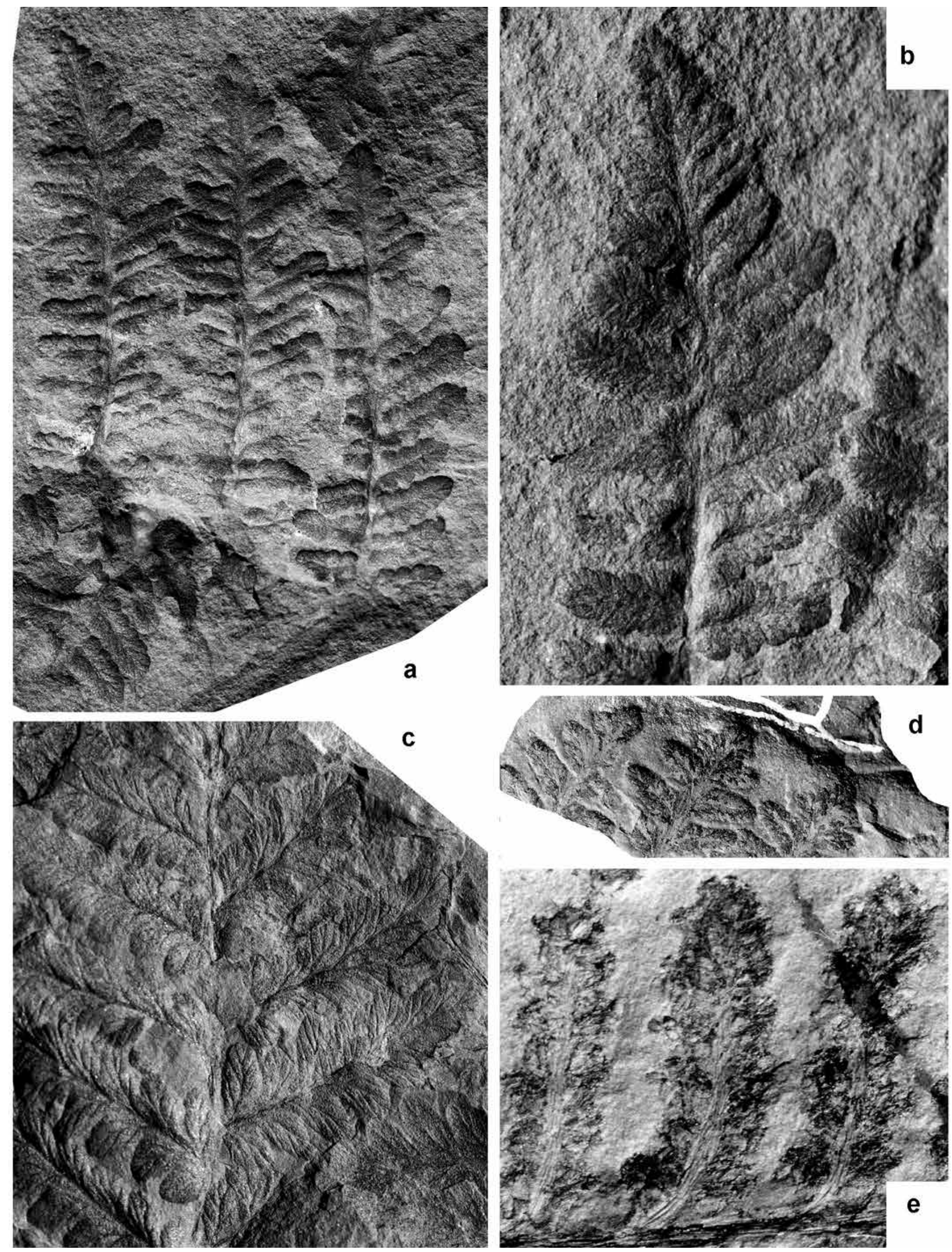
specimen from New Brunswick not available for revision that raises some doubts about its attribution to Zeilleria avoldensis).

* p 1951 Pecopteris tenuinervosa Corsin, p. 310-311, pl. CLXIV, fig. 3; non pl. CLXIV, fig. 4 (= Pecopteris micromiltonii) (acc. to Brousmiche and Laveine 1982).

1951 Pecopteris cf. avoldensis (Stur) Corsin; Corsin, p. 355-356, pl. CLXXXIV, figs. 1-2a.

* 1958 Zeilleria lignyi Stockmans and Willière, pl. VII, figs. 1-4 (well illustrated but only diagnosed briefly in the plate explanation); pl. VIII, figs. 1-4 (fertile specimens assigned to Bertrandia by Dalinval 1960) (acc. to Álvarez-Vázquez 1995).

1960 Pecopteris (Bertrandia) avoldensis (Stur) Dalinval (including synonymy), p. 185-194, pl. LVII, figs. 1-3a; pl. LVIII, figs. 1-3a; pl. LIX, figs. 1-3a; pl. LX, figs. 1-4a; pl. LXI, figs. 1-3a.

1960 Pecopteris (Asterotheca) miltoni (Artis) Zeiller; Dalinval, pl. 33, figs. 1-3a; pl. 34, figs. 1-3a; pl. 35, figs. 1-2a; pl. 36, figs. 1-4a; pl. 40, fig. 1 (with doubt); non p. 133-149, non pl. 32, figs. 1-1b (= Pecopteris pseudovestita); non pl. 37, figs. 1-1a (= Pecopteris cf. miltonii); non pl. 37, figs. 2-2a (= Pecopteris sp.); non pl. 37, fig. 3 (= Pecopteris miltonii); pl. 38, figs. 1-2a (= Pecopteris miltonii); pl. 39, figs. 1-2b (= Pecopteris cf. miltonii); non pl. 40, figs. 2-3 (fertile pinnules of Asterotheca-type different to that shown by Pecopteris miltonii) (acc. to Wagner and Álvarez-Vázquez 2016).

1960 Pecopteris; Gillespie and Latimer, p. 53, pl. 17, fig. 4.

1965 Pecopteris cf. miltoni (Artis) Brongniart; Stockmans and Willière, pl. IV, figs. 2-3.

1966 Zeilleria avoldensis (Stur) Kidston; Bell, p. 28, pl. XIII, fig. 4.

* 1966 Asterotheca praecursor Stockmans and Willière, p. 8-9, pl. III, figs. 1-4a (compared with Bertrandia avoldensis and Pecopteris miltonii by Stockmans and Willière).

* 1966 Asterotheca inferior Stockmans and Willière, p. 9, pl. IV, figs. 1-3a (fertile specimens from the same locality as those of Asterotheca praecursor).
1966 Pecopteris; Gillespie et al., p. 100, pl. 30, fig. 2 (same as Gillespie and Latimer 1960, pl. 17, fig. 4).

1970 Pecopteris avoldensis (Stur) Corsin; Laveine, p. 282-286, pl. 37, figs. 1-1a (same as Dalinval 1960, pl. LX, fig. 3); figs. 1b-k (spores); pl. 38, figs. 1-2a, 3-3a (with cf.); figs. 2b-f, 3b-g (spores).

* 1971 Pecopteris alloiophylla Doubinger and Germer, p. 74, Abb. 2, Taf. 21, figs. 1a-b (acc. to Brousmiche and Laveine 1982).

* 1971 Pecopteris engyphylla Doubinger and Germer, p. 75-76, Abb. 5, Taf. 21, figs. 4a-b (acc. to Brousmiche and Laveine 1982).

* 1971 Pecopteris pachyneura Doubinger and Germer, p. 81, Abb. 12, Taf. 23, figs. 3a-b (acc. to Brousmiche and Laveine 1982).

* 1971 Pecopteris pycnoneura Doubinger and Germer, p. 83, Abb. 14, Taf. 24, figs. 1a-c (acc. to Brousmiche and Laveine 1982).

* 1971 Pecopteris brachyphylla Doubinger and Germer, p. 83, Abb. 15, Taf. 24, figs. 2a-b (acc. to Brousmiche and Laveine 1982).

1971 Zeilleria avoldensis (Stur) Kidston; Thomas and Crampton, p. 283-294, pl. I, figs. A-G; pl. II, figs. A-I (spores); text-figs. 1-3 (drawings).

T 1982 Pecopteris (Zeilleria) avoldensis (Stur) Kidston; Brousmiche and Laveine, p. 52-58 (including synonymy), pl. I, figs. 1-1b (neotype as designated by Brousmiche 1983), figs. 2-3b; pl. II, figs. 1-8a, figs. 9-9a (same as Corsin 1951, pl. CLXIV, fig. 3); pl. III, figs. 1-8a; pl. IV, figs. 1-1a, 11-11a, figs. 2-10, 12 (spores); text-figs. $1 \mathrm{~A}-2$.

1983 Zeilleria avoldensis (Stur) Kidston; Brousmiche, p. 215-217, pl. 52, figs. 1-1a (same as Corsin 1951, pl. CLXIV, fig. 3), figs. 2-8a.

1985 Sphenopteris sp. A; Lyons et al., p. 228, 234, pl. XI, fig. e.

v 2001b Zeilleria pilosa (Dawson) comb. nov. Wagner, p. 95, fig. 46 (same as figured as Zeilleria avoldensis by Álvarez-Vázquez 1995, lám. 54, fig. 1).

2002 Zeilleria cf. avoldensis (Stur) Kidston; Blake et al., p. 268, 291, 317, pl. XVII, fig. 5 (fertile).

Figure 2. (previous page) (a) Zeilleria avoldensis $(\times 3)$. GSC 9986. Fragment of penultimate order pinna. Origin: South Brook, tributary of Maccan River, at position of Barlow seam (locality 1086), Nova Scotia. (b) Zeilleria avoldensis. Enlargement $(\times 6)$ of part of Fig. 2a showing the short, rounded and fused terminal of last order pinnae, and subrectangular fully developed pinnules, showing a slightly constricted base, lobed margins and rounded apex. (c) Zeilleria avoldensis $(\times 6)$. Specimen without catalogue number. Origin: Maccan River, Springhill area, about 0.8 kilometres west of Mapleton (locality 999), Nova Scotia. (d) Zeilleria avoldensis ( $\times 3$ ). GSC 10970. Terminals of last order pinnae. Figured as Pecopteris pilosa by Bell (1944, pl. XL, figs. 3, 4). Origin: Spicer's Cove (wrongly cited as Sprier Cove by Bell, 1944, p. 115), from beds a little below bed 28, section 11 of $\mathrm{H}$. Fletcher (locality 1342), Nova Scotia. (e) Zeilleria avoldensis $(\times 6)$. GSC 8218. Detail of the specimen figured as Pecopteris pilosa in Bell $(1944$, pl. XLII, figs. 1, 6) showing fertile pinnules with mature synangia split into four segments. Origin: Spicer's Cove, from beds a little below bed 28, section $11 \mathrm{of} \mathrm{H}$. Fletcher (locality 1342), Nova Scotia. Repository: Geological Survey of Canada, Ottawa. 
2010 Zeilleria avoldensis (Stur) Kidston; Wagner and Álvarez-Vázquez, p. 257, 266, 268, 270, 307.

Description. Frond at least tripinnate. Antepenultimate rachis straight, longitudinally striate, ca. $2 \mathrm{~mm}$ wide. Pinnae of penultimate order alternate, probably lanceolate (incompletely preserved), touching laterally or slightly overlapping. Dimensions: at least $70 \mathrm{~mm}$ long and $25 \mathrm{~mm}$ broad. Penultimate rachis inserted at narrow angle, rounded, straight, longitudinally striate, ca. $0.4-0.5 \mathrm{~mm}$ wide. Last order pinnae alternate, lanceolate, generally touching laterally, with a rounded, poorly individualized terminal; dimensions: $10-30 \mathrm{~mm}$ long and $5-10 \mathrm{~mm}$ broad; length/breadth ratio = 2-3. Last order rachis rounded, straight, longitudinally striate, ca. $0.1 \mathrm{~mm}$ wide. Pinnules alternate, ovate to subrectangular, inserted slightly obliquely and broadly attached (pecopteroid). Fully developed pinnules subrectangular, with a slightly constricted base, lobed margins and rounded apex. Dimensions: 4-6 mm long and 1.5-2 mm broad; length/breadth ratio $=2.6-3$. Smaller, less individualized pinnules ovate, united for up to one half of their length. Dimensions: 3-4 $\mathrm{mm}$ long and 1.5-2 $\mathrm{mm}$ broad; length/ breadth ratio $=2$. Nervation well-marked, deeply embedded in the convex lamina. Midrib slightly decurrent and extending into the pinnule apex; lateral veins once or twice forked. Fertile pinnules similar in shape to the vegetative ones. Immature synangia oval, placed at the end of lateral veins. Mature synangia extend beyond a slightly reduced lamina; at full maturity these split into four or five sporangia.

Remarks. Stopes (1914) figured photographically the specimens of Sphenopteris pilosa that were illustrated by diagrammatic drawings by Dawson $(1868,1871)$. She included this species in synonymy with Pecopteris miltonii, apparently in error (Wagner and Álvarez-Vázquez 2016). Stopes (1914) also synonymized Dawson's (1871) Pecopteris densifolia with Pecopteris miltonii. Bell (1944, p. 85) agreed with Stopes (1914) that the vegetative remains of Sphenopteris pilosa resemble those of Pecopteris miltonii, but he regarded the synangia as different. He thus rejected Stopes's synonymy and reinstated Dawson's species as Pecopteris pilosa. The correct identification of Pecopteris miltonii is a problem that was dealt with by Wagner and Álvarez-Vázquez (2016) based on a redescription of material from the type area of the species in South Yorkshire, England, and other European localities. Wagner and Álvarez-Vázquez (2016) indicated in their synonymy list that specimens belonging to Zeilleria avoldensis have often been mistaken for Pecopteris miltonii.

The type material of Sphenopteris pilosa, figured and described by Dawson $(1868,1871)$ and Stopes (1914), originated from the Fern Ledges locality at Saint John, New Brunswick. Additional specimens from Nova Scotia, including fertile remains, were figured and described as Pecopteris pilosa by Bell (1944). Bell's specimens have been re-examined in present study and compared with European material of Zeilleria avoldensis. At least one of the fertile specimens from Nova Scotia figured by Bell (1944, pl. XXXIX, fig. 3; pl.
XL, fig. 2) shows fully opened synangia situated at the tip of pinnule lobes. This specimen closely resembles that figured by Thomas and Crampton (1971) from lower Bolsovian strata of Great Britain. Bell's specimens should be included in Zeilleria avoldensis.

Zeilleria avoldensis was revised by Brousmiche and Laveine (1982), who clarified many misidentifications and included several species in synonymy. European specialists consistently ignored the Canadian material until Wagner (2001b) introduced the new combination Zeilleria pilosa in a list of species of the Peñarroya-Belmez-Espiel coalfield, southwestern Spain, thus placing Zeilleria avoldensis in synonymy with Sphenopteris pilosa.

I have not been able to review Dawson's types of Sphenopteris pilosa and Pecopteris densifolia; thus here they have been included only questionably in synonymy with Zeilleria avoldensis. If future work confirms the synonymy of Zeilleria avoldensis with one or more of the earlier names, a formal proposal should be made to conserve Zeilleria avoldensis. The very small fragments figured by Dawson (1868) as Sphenopteris pilosa contrast with the large, well-preserved fertile specimen figured and described by Stur (1885, Taf. XXXVII, fig. 1) on which Zeilleria avoldensis is based. Most important is the widespread use of Zeilleria avoldensis in the paleobotanical literature, whereas Zeilleria pilosa has been rarely used.

Comparisons. Zeilleria avoldensis is easily distinguished from the other species of Zeilleria by its thick, convex lamina, and the presence of pecopteroid pinnules.

Stratigraphic and geographic distribution. Zeilleria avoldensis is known from numerous localities in Europe, where it has been commonly recorded, although not always under this name (see synonymy list). It is long-ranging, from (Yeadonian?) Langsettian to middle Asturian. Stur's type material originated from middle Bolsovian strata of Saar-Lorraine. Corsin's (1951) Pecopteris tenuinervosa and the five species distinguished by Doubinger and Germer (1971) all came from different levels of Bolsovian and Asturian strata in Saar-Lorraine. The type materials of Zeilleria lignyi, Asterotheca inferior and Asterotheca praecursor came from upper Langsettian strata in Belgium. Wagner and Álvarez-Vázquez (2010) recorded the species from various levels of Langsettian to lower Asturian strata in different parts of the Iberian Peninsula. The few records of Zeilleria avoldensis from the USA may not properly reflect its occurrence in North America as it seems to be one of the more common fern species in the Maritime Provinces of Canada.

Occurrence in the Maritime Provinces, Canada. CumBERLAND BASIN (Nova Scotia): Bell (1944): locality 999 (GSC 8205 + GSC 8596 + GSC 8597 - fragmentary + five pieces without catalogue number - together with Alethopteris urophylla, Annularia ramosa and Asterophyllites sp.); locality 1031 (GSC 8208 - fertile + one piece with damaged catalogue number); locality 1086 (GSC 9986 - together 
with Calamites carinatus); locality 1088 (GSC 10116 with Calamites sp. and Asterophyllites sp.); locality 1010 (GSC 8661); locality 1342 (GSC 8218 + GSC 10970); locality 1389 (GSC 8211 + GSC 10010 + GSC 10011); locality 1406 (fertile specimens - two pieces, part and counterpart, without catalogue number); locality 2253 (two pieces without catalogue number - fragmentary; together with Laveineopteris polymorpha); locality 3115 (one piece without catalogue number - fragmentary); locality 3995 (one piece without a catalogue number - together with Samaropsis sp.); locality 5868 (three pieces without catalogue number - fragmentary and poorly preserved). COLLECTED IN 1960: locality 5644 (one piece without catalogue number). SAInt John (New Brunswick): Bell (1944): locality 203 (one piece without catalogue number - fragmentary); locality 351 (one piece - fragmentary); locality 352 (one piece without catalogue number); locality 559 (GSC $8201-$ fragmentary); locality 785 (GSC 8204). NEw BRUNSWICK MuSEum COLLECTION: NBMG 1842 (fragmentary; with cf.) + NBMG 10532 (labelled as Sphenopteris pilosa) + NBMG 12049/1 (together with Dorycordaites palmaeformis) + NBMG 12049/2 + NBMG 12049/3 + NBMG 12049/4 (together with Dorycordaites palmaeformis). Sydney BAsIN (Nova Scotia): Bell (1938): locality 480 (GSC 1669); locality 518 (GSC 3057 + GSC 3058). Bell (1966): locality 480 (GSC 15049).

Occurrence in the United States. Alabama: Lyons et al. (1985). West Virginia: Gillespie and Latimer (1960), Gillespie et al. (1966), Blake et al. (2002).

Zeilleria frenzlii (Stur 1883) Kidston 1884

(Figs. 3a-d)

* 1883 Calymmotheca Frenzli Stur, p. 172 [804], Figs. $38 \mathrm{a}-\mathrm{b}$.

$\$ 1884$ Zeilleria Frenzlii (Stur) Kidston, p. 591.

1885 Calymmotheca Frenzli Stur, p. 268-272, Taf. XXXVII, figs. 2-3; Taf. XXXVIII, fig. 3; textfigs. $42 \mathrm{a}-\mathrm{b}$.

* 1885 Calymmotheca Walteri Stur, p. 263-264, Taf. XXXVI, fig. 4 (specimen from the same horizon as two of the three other specimens figured by Stur 1885 as Calymmotheca frenzlii).

1914 Sphenopteris (Zeilleria) Frenzli (Stur) Kidston; Carpentier and Depape, p. 307-310, pl. IV, figs. 1-4 (magnificent fertile specimens), fig. 5 (sporangia); pl. VI, fig. 1; text-figs. 1-2.

* 1937 Hymenotheca globulifera Němejc, p. 9, pl. II, figs. 5, 6 (Němejc made comparisons with Zeilleria frenzlii and Crossotheca schatzlarensis).

1938 Zeilleria frenzli (Stur) Kidston; Bell, p. 34, pl. XX, figs. 2-3; pl. XXI, fig. 2.

p 1938 Hymenotheca dathei Potonié; Bell, p. 36, pl. XX, fig. 4; pl. XXI, fig. 1; non pl. XXIII, figs. 4-5 (difficult to judge, but the specimen shows pinnules with a broader lamina than Zeilleria frenzlii).
1941 Sphenopteris cf. sancti felicis (Stur) Rydzewski; Gothan, p. 11-12, Taf. 49, fig. 3 (Stur's Diplotmema sancti-felicis is a pteridosperm, not a fern).

T 1943 Zeilleria frenzli (Stur) Kidston; Guthörl, p. 144, Taf. XXIX, Abb. 2A-2B, Abb. 3A-3B (neotype designated by Brousmiche 1983).

v 1944 Sphenopteris dixoni Kidston; Bell, p. 67, pl. XIV, figs. 2-3 (fragmentary).

${ }^{*} \mathrm{v} 1944$ Sphenopteris fletcheri Bell, p. 68, pl. XVI, fig. 2 (paratype); pl. XVI, fig. 6 (holotype - Figs. $3 a-b$ herein).

v 1944 Zeilleria frenzli (Stur) Kidston, Bell, p. 73, pl. XXII, figs. 1-2; pl. LXXVII, fig. 6; pl. LXXVIII (partially refigured in Figs. $3 c-d$ ); pl. LXXIX, figs. 2-3.

1958 Zeilleria frenzli (Stur) Kidston; Langford, p. 282, Fig. 518; Fig. 519a (drawing).

v 1965 Zeilleria frenzli (Stur) Kidston; Wagner, p. 88-90, pl. 11, figs. 17-18.

1969 Zeilleria frenzli (Stur) Kidston; Skog et al., Figs. 10-11; Fig.12 (spores).

1983 Zeilleria frenzli (Stur) Kidston; Brousmiche, p. 205-212 (including synonymy), pl. 49, figs. 1-5, figs. 6-6a (same as Álvarez Ramis et al. 1978, Taf. 9, fig. 1); pl. 50, figs. 1-4; text-figs. $61 \mathrm{~A}_{1}-\mathrm{E}_{3}$.

p 1985 Zeilleria delicatula Kidston; Gillespie and Crawford, p. 252, pl. II, fig. 4 (?), fig. 5 (fertile); non pl. II, fig. 3 (= Renaultia schatzlarensis).

p 2002 Zeilleria frenzlii (Stur) Kidston; Blake et al., p. 268, 291, pl. XVII, fig. 2; non pl. XVII, fig. 3 (= Renaultia schatzlarensis).

v 2010 Zeilleria frenzlii (Stur) Kidston; Wagner and Álvarez-Vázquez, p. 257, 266.

Excludenda:

2017 cf. Zeilleria frenzlii (Stur) Kidston; DiMichele et al., p. 53-54, 55, figs. 31.10-31.11 (small, fragmentary specimen resembling Germera mendescorreae).

Description. Frond at least tripinnate. Penultimate rachis straight, flat, longitudinally striate, ca. $1 \mathrm{~mm}$ wide. Last order pinnae lanceolate, alternate or subopposite, laterally touching or slightly overlapping. Dimensions: $10-40 \mathrm{~mm}$ long and $6-13 \mathrm{~mm}$ broad; length $/$ breadth ratio $=1.6-3$. Last order rachis inserted at $45-80^{\circ}$, straight, flat, longitudinally striate, narrowly winged due to decurrent, confluent pinnule bases, ca. $0.7 \mathrm{~mm}$ wide. Pinnules alternate or subopposite, obliquely inserted; less developed pinnules (in the apical parts of pinnae) consist of one or two linear segments with slightly pointed apices (which may appear subrounded as a result of imperfect preservation). More fully developed pinnules are deeply incised and split into five to six parallelsided, narrowlobes, with acute apices. Dimensions: 5-12 mm long and $1.5-5 \mathrm{~mm}$ broad; length/breadth ratio $=2.4-3.25$. A single, relatively thick vein enters each lobe extending into the apex. Fertile pinnules with narrower lobes than those of 


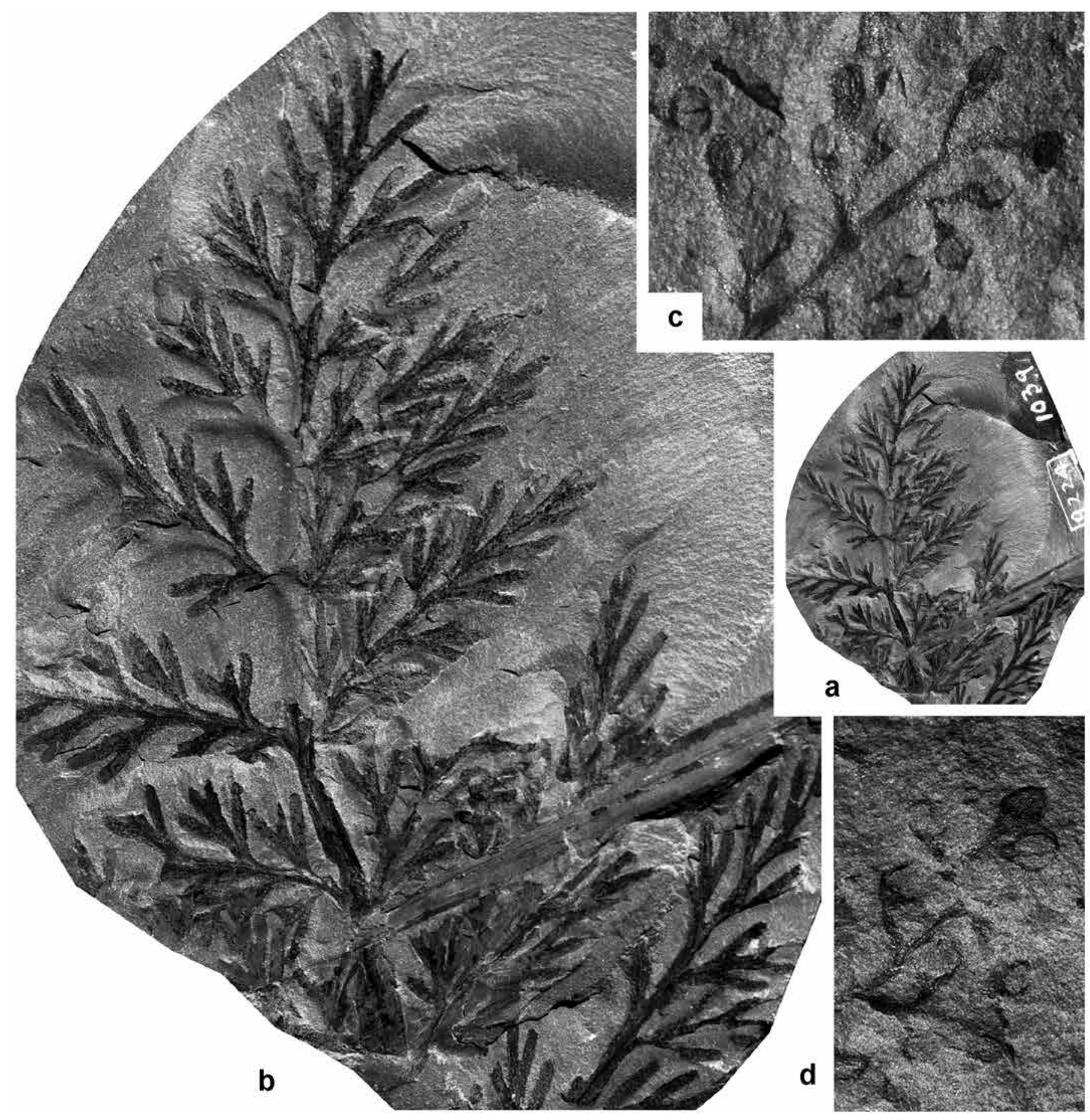

Figure 3. (a) Zeilleria frenzlii ( $\times 1)$. GSC 9224. Holotype of Sphenopteris fletcheri Bell (1944, pl. XVI, fig. 6). Origin: Springhill, $n^{\circ} 2$ mine, waste dump (locality 1039), Nova Scotia. (b) Enlargement $(\times 3)$ of specimen in Fig. 3a. Note the characteristic parallel-sided, narrow lobes, with acute apices. (c) Zeilleria frenzlii $(\times 6)$. GSC 10052. Detail of the fertile specimen with immature sporangia at the end of lobes figured by Bell (1944, pl. LXXVIII; pl. LXXIX, fig. 3). Origin: South Brook, tributary of Maccan River, at position of Barlow seam (locality 1086), Nova Scotia. (d) Another detail $(\times 6)$ of the same specimen in Fig. 3c. Repository: Geological Survey of Canada, Ottawa.

vegetative ones. Sporangia globular, relatively large (1-1.2 mm), placed at the end of lobes; when fully mature, the sporangia split into four segments.
Remarks. The thin, almost filiform segments into which the pinnules of Zeilleria frenzlii are split clearly distinguish this species, especially when sporangia are present. Fertile specimens were well illustrated by Bell (1944, pl. XXII, fig. 1; 
pl. LXXVII, fig. 6; pl. LXXVIII; pl. LXXIX, figs. 2-3).

Bell $(1944$, p. 68, pl. XVI, figs. 2, 6) introduced a new species, Sphenopteris fletcheri, from two localities in the Cumberland Basin of Nova Scotia. He compared it with two pteridosperm taxa, Sphenopteris alata (= Palmatopteris alata) and Diplotmema furcatum (= Palmatopteris furcata), although the comparison now appears to be irrelevant. Bell apparently overlooked Zeilleria frenzlii, which I regard as the senior synonym of Sphenopteris fletcheri. No subsequent records of Sphenopteris fletcheri are known.

I also include in Zeilleria frenzlii the fragmentary specimen figured by Bell (1944, pl. XIV, figs. 2-3) as Sphenopteris dixonii. This specimen shows slightly decurrent, linear, trilobed pinnules with narrow pointed lobes, which are essentially identical to those of Stur's species. Kidston's (1917) Sphenopteris dixonii possesses smaller, Corynepteris-type pinnules inserted in parallel-sided pinnae; these pinnules are cuneate and show two, or rarely three, blunt segments on the upper margin.

Comparisons. Vegetative pinnules of Zeilleria schaumburg-lippeana have broader lamina and obtusely pointed lobes. According to Brousmiche (1983), Zeilleria frenzlii has pinnules that are one and a half times longer than those of Zeilleria schaumburg-lippeana at the same stage of differentiation. Vegetative pinnules of Germera brousmicheae sp. nov. (see below) also possess up to three pairs of parallelsided lobes, but these display a much wider lamina and markedly more rounded or tongue-shaped apices.

Stratigraphic and geographic distribution. Zeilleria frenzlii is a widespread species, ranging from Langsettian to upper Bolsovian. The holotype is from lower Bolsovian strata of Saar-Lorraine, from where Brousmiche (1983) noted that the species is common throughout the Bolsovian. Nermejc's (1937) Hymenotheca globulifera originated from Bolsovian strata of the Lubná group of coals, Upper Radnice, Kladno Basin, Bohemia, Czech Republic.

Occurrence in the Maritime Provinces, Canada. CumBERLAND BASIN (Nova Scotia): Bell (1944): locality 1039 (GSC 9064 - figured as Sphenopteris fletcheri + GSC 9224 - holotype of Sphenopteris fletcheri; together with Cyperites sp.); locality 1086 (GSC 10038 + GSC 10052 + GSC 10054 + GSC 10056 - all fertile remains); locality $1141=666$ (GSC $10243+$ GSC 10244 - part and counterpart; figured as Sphenopteris dixonii by Bell); locality 1362 (GSC 10976 + one fragmentary specimen without catalogue number); locality 1462 (one piece without catalogue number - together with rootlets); locality 1517 (one piece from a borehole without catalogue number); locality 2253 (one piece without catalogue number - together with Laveineopteris polymorpha, Renaultia sp. and Dorycordaites palmaeformis). Sydney BAsin (Nova Scotia): Bell (1938): locality 482 (GSC 1641); locality 484 (GSC 1639).

Occurrence in the United States. Georgia: Gillespie and
Crawford (1985); Blake et al. (2002). ILLINOIs: Langford (1958).

Zeilleria hymenophylloides Kidston 1924

(Figs. 4a-b; Figs. 5a-b)

p 1916 Sphenopteris Kayi Arber, pl. 2, fig. 3; non p. 142-143, pl. 2, fig. 6 (excluding the holotype).

1924 Zeilleria hymenophylloides Kidston, p. 439-440, pl. XCVII, fig. 1 (lectotype designated by Brousmiche 1983), pl. XCVII, figs. 2-2a; pl. XCIX, figs. 9-11.

p 1928 Zeilleria hymenophylloides Kidston; Němejc, p. 1-2, pl. I, fig. 1, figs. 2-4 (sporangia); non pl. II, fig. 1 (difficult to judge from the illustration).

1933 Zeilleria fructification; Arnold, p. 822, figs. 1-2 (drawings), fig. 3 (spores).

* 1937 Zeilleria stellata Arnold, p. 4, pl. 1, fig. 4 (same as Arnold 1933).

1941 Sphenopteris (Zeilleria) hymenophylloides (Kidston) Gothan, p. 17, Taf. 52, figs. 4-5a; Taf. 53, fig. 2.

v 1944 Sphenopteris (Zeilleria) hymenophylloides (Kidston) Gothan; Bell, p. 72-73, pl. XIII, fig. 6; pl. XX, fig. 3 (herein Fig. 4b); pl. XXII, fig. 3 (poorly preserved).

1944 Sphenopteris moyseyi Kidston; Bell, p. 66, pl. XIV, fig. 4.

v 1944 Zeilleria schaumberg-lippeana (sic) (Stur) Zeiller; Bell, p. 73-74, pl. XXIII, figs. 4-5; pl. XXIV, fig. 3.

? 1958 Zeilleria delicatula Kidston; Langford, p. 282, Fig. 519-2a (drawing); Fig. 520 (poor figure).

1983 Zeilleria hymenophylloides Kidston; Brousmiche, p. 213-215 (including synonymy), pl. 51, figs. 1-3a (same as Kidston 1924, pl. XCIX, figs. 9-11), figs. 4-5, figs. 6-8 (as Zeilleria cf. hymenophylloides).

v 1987 Zeilleria hymenophylloides Kidston; Wagner, lám. 8, figs. 1-2.

1988 Zeilleria hymenophylloides Kidston; Amerom, p. 97-102, pl 1, figs. 1-7; pl. 2, figs. 1-6; textfigs. 1-4.

v 1995 Zeilleria hymenophylloides Kidston; ÁlvarezVázquez, p. 179-181 (including synonymy), lám. 54, fig. 1 (together with Zeilleria avoldensis and Paripteris sp.); lám. 56, fig. 3; lám. 58, fig. 1 (same as Wagner 1987, lám. 8, fig. 1, at natural size), fig. 3; lám. 59, fig. 1 (same as Wagner 1987, lám. 8, fig. 1, enlarged), figs. 2-3; pl. 60, figs. 1-5.

v 2001b Zeilleria hymenophylloides Kidston; Wagner, p. 95, fig. 44 (same as Wagner 1987, lám. 8, fig. 1, and Âlvarez-Vázquez, 1995, lám. 58, fig. 1; lám. 59, fig. 1), fig. 45.

v 2010 Zeilleria hymenophylloides Kidston; Wagner and Álvarez-Vázquez, p. 254, 255, 257, 266, 307, pl. V, fig. 1. 

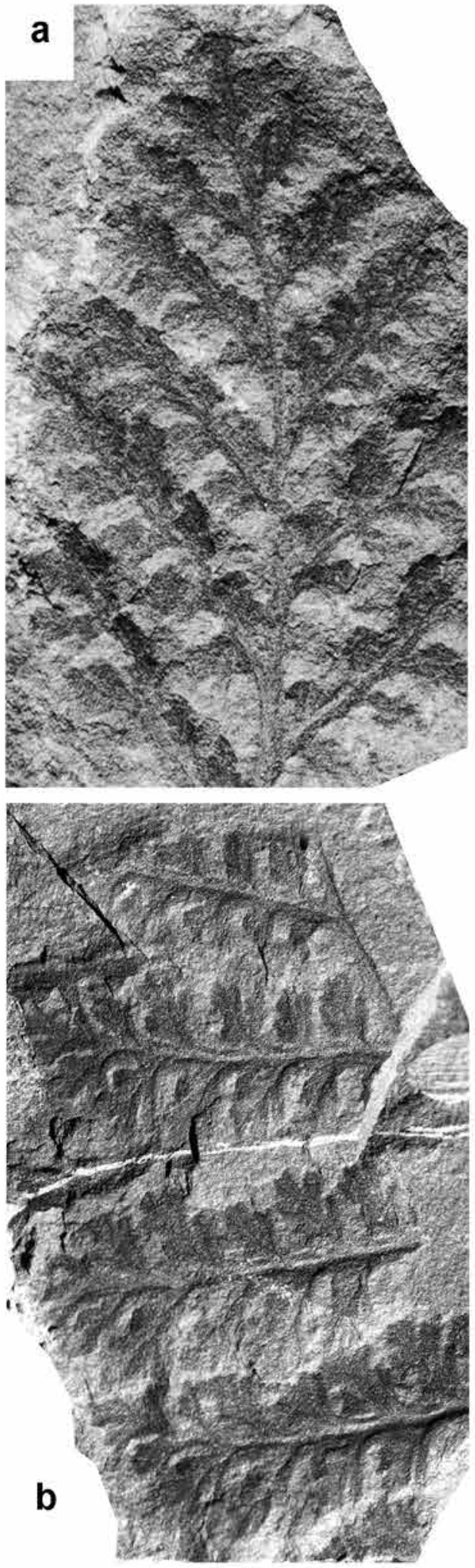

Description. Frond at least tripinnate. Antepenultimate rachis straight, smooth, ca. $2 \mathrm{~mm}$ wide. Pinnae of penultimate order alternate, well spaced, apparently subrectangular (always incomplete), at least $45 \mathrm{~mm}$ long and $20 \mathrm{~mm}$ broad. Penultimate rachis inserted at $45-50^{\circ}$, straight, smooth, ca. $0.7 \mathrm{~mm}$ wide. Last order pinnae alternate, closely spaced but
Figure 4. (a) Zeilleria hymenophylloides $(\times 3)$. Specimen without catalogue number. Terminal of a penultimate order pinna with poorly preserved pinnules in different stages of development. Origin: Near Pudsey Point, Joggins section (locality 3109), Nova Scotia. (b). Zeilleria hymenophylloides $(\times 3)$. GSC 9217. Specimen showing fully developed, vegetative pinnules. Previously figured by Bell $(1944, \mathrm{pl}$. XX, fig. 3). Origin: McCoy Head, Saint John County (locality 2567), New Brunswick. Repository: Geological Survey of Canada, Ottawa.

not touching, subrectangular, elongate, $10-20 \mathrm{~mm}$ long and $3-6 \mathrm{~mm}$ broad; length/breadth ratio $\approx 3.3$. Last order rachis inserted at $75-80^{\circ}$, straight, smooth or showing a faint longitudinal striation, ca. $0.2-0.3 \mathrm{~mm}$ wide. Pinnules alternate, decurrent, attached to the rachis by a wide footstalk; general oultine ovate and divided into two to five simple or bifid pairs of lobes with obtusely pointed apices; terminal lobe simple of bifid. Dimensions: 3-5 mm long and 2-3 mm broad; length/breadth ratio $=1.5-1.6$. Lamina thick, convex. Midrib thin, slightly flexuous, once or twice bifurcate, remaining well developed to near the pinnule apex.

Remarks. Although fragmentary and poorly preserved, I agree that the two specimens illustrated by Bell (1944, pl. XIII, fig. 6; pl. XX, fig. 3; pl. XXII, fig. 3) should be assigned to Sphenopteris (Zeilleria) hymenophylloides. The better preserved specimen figured as Sphenopteris moyseyi by Bell (1944, pl. XIV, fig. 4), originating from the same locality as one of Bell's specimens identified as Zeilleria hymenophylloides (locality 2567), may also belong to this species.

The two specimens figured by Bell (1944, pl. XXIII, figs. 4-5; pl. XXIV, fig. 3) as Zeilleria schaumburg-lippeana were incorporated by Brousmiche (1983, p. 353) in her synonymy list for Zeilleria hymenophylloides. However, she emphasized the poor quality of Bell's illustrations and preferred to attribute the material to Sphenopteris incertae sedis. Although the delicate lamina is poorly preserved, Bell's specimens clearly possess fertile, decurrent, ovate pinnules with simple or bifid, obtusely pointed lobes. Re-examination of Bell's specimens, along with thirteen additional from Bell's locality 788 , confirms that these specimens should be attributed to Zeilleria hymenophylloides.

Zeilleria hymenophylloides has been figured and described in detail by Brousmiche (1983), Amerom (1988) and Álvarez-Vázquez (1995) from various parts of western Europe.

Comparisons. The pecopteroid aspect and thick, subrectangular lamina of vegetative pinnules of Zeilleria avoldensis make this species easily distinguishable from Zeilleria hymenophylloides. The latter species shows more sphenopteroid, ovate pinnules divided into simple or bifid lobes; the pinnules are attached to the rachis by a wide footstalk. Zeilleria frenzlii differs in having longer, more narrowly winged pinnules, divided into more filiform lobes. 

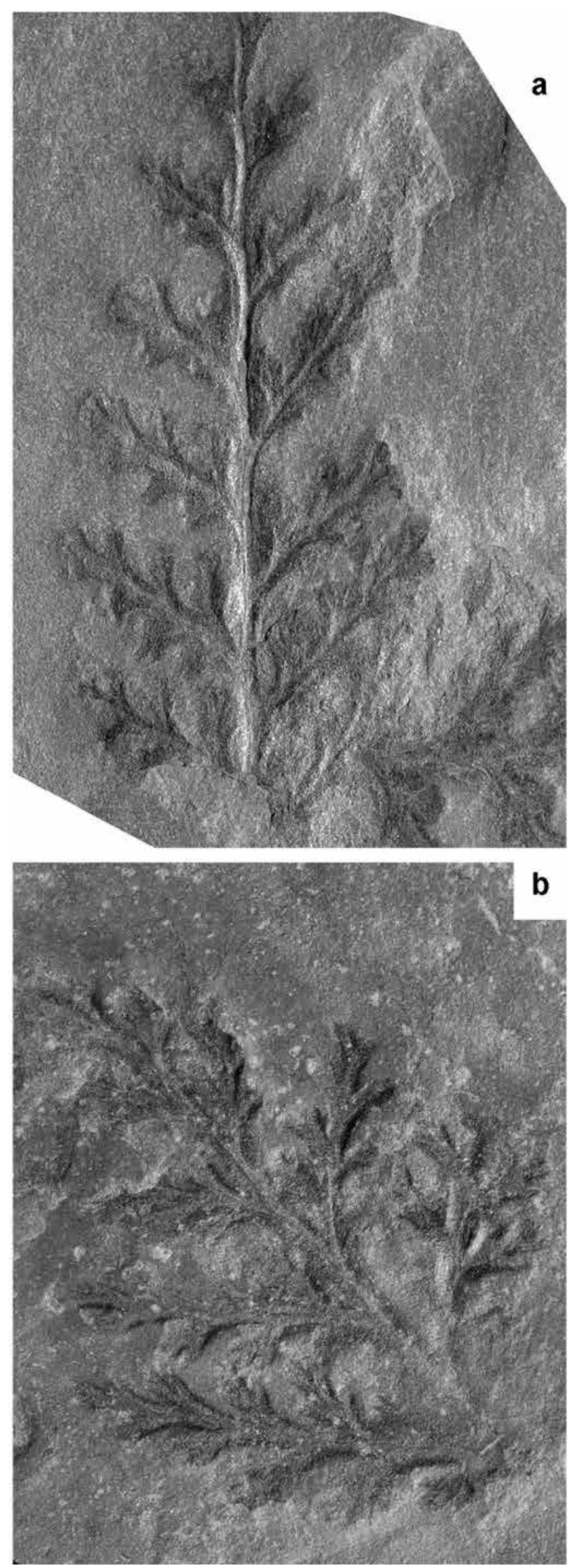

Figure 5. (a) Zeilleria hymenophylloides $(\times 3)$. Terminal part of penultimate order pinna. Specimen without catalogue number. Origin: Fern Ledges, Saint John (locality 476), New Brunswick. (b). Zeilleria hymenophylloides $(\times 3)$. Another terminal of a pinna of the penultimate order, originating from the same locality as the specimen in Fig. 5a. Repository: Geological Survey of Canada, Ottawa.

Stratigraphic and geographic distribution. Zeilleria hymenophylloides is a rarely recorded species. ÁlvarezVázquez (1995) gives its total range as middle Langsettian to middle Bolsovian. Kidston's holotype originated from upper Langsettian strata of the Lancashire coalfield of England. Brousmiche (1983) recorded the species (as Zeilleria cf. hymenophylloides) from middle Westphalian C (Bolsovian) of Saar-Lorraine. Amerom's (1988) specimens are from Langsettian strata of South Limburg, the Netherlands.

Occurrence in the Maritime Provinces, Canada. CumberLAND BASIN: Bell (1944): locality 1031 (one poorly preserved specimen without catalogue number - together with Cordaites sp.); locality 3109 (GSC 5596 + five pieces without catalogue number). SAINT John (New BrUnswick): Bell (1944): locality 701 (one poorly preserved specimen without catalogue number); locality 788 (GSC 10978 - fertile specimen figured as Zeilleria schaumburg-lippeana by Bell + fourteen pieces without catalogue number); locality 808 (one piece without catalogue number - fragmentary and poorly preserved); locality 1498 (two pieces without catalogue number); locality 2567 (GSC 9217 + GSC 9375 - figured as Sphenopteris moyseyi + two poorly preserved specimens without catalogue number); locality 2569 (GSC 5598 + two pieces without catalogue number - fragmentary and poorly preserved). Fundy Geological Museum: FGM 997 GF 31.14 (fragmentary and poorly preserved - together with Laveineopteris polymorpha and Dorycordaites palmaeformis).

Occurrence in the United States. ILLINOIS: Langford (1958). Michigan: Arnold $(1933,1937)$.

Genus Renaultia Zeiller 1883

1883 Renaultia Zeiller, p. 185 (August).

1883 Hapalopteris Stur, p. 660 [28] (December).

1956 Renaultia Zeiller; Danzé, p. 69-70, 171-175.

1983 Renaultia Zeiller; Brousmiche, p. 138-140.

Type. Renaultia chaerophylloides (Brongniart 1836) Zeiller 1883.

Remarks. Renaultia encompasses small-pinnuled ferns characterized by a delicate, more or less reduced lamina, and sporangia situated at the vein endings and either single or arranged in groups of two to five. Zeiller (1883, August) introduced Renaultia to incorporate fertile remains previously assigned to Pecopteris chaerophylloides. Almost 
simultaneously, Stur (1883, December) proposed Hapalopteris for Hapalopteris typica, a synonym of Renaultia chaerophylloides.

\section{Renaultia footneri (Marrat 1872) Kidston 1893} (Fig. 6)

* 1872 Sphenopteris Footneri Marrat, p. 94, pl. VIII, figs. 2-3.

T 1889 Sphenopteris Footneri Marrat; Kidston, p. 406-407, pl. II, figs. 3-3b.

$\$ 1893$ Renaultia footneri (Marrat) Kidston, p. 104.

T 1924 Sphenopteris Footneri Marrat; Kidston, p. 117120 , pl. XXIV, figs. 1-1b (lectotype designated by Brousmiche 1983), figs. 2-6; pl. XXV, fig. 5.

v 1944 Sphenopteris (Renaultia) gracilis (Brongniart) Zeiller; Bell, p. 72, pl. XX, figs. 1-2 (herein Fig. 6).

1956 Sphenopteris footneri Marrat; Danzé, p. 444448, pl. LXXII, figs. 1-3; pl. LXXIV, figs. 1-1b.

T 1981 Sphenopteris footneri Marrat; Cleal, p. 15, pl. 3, fig. 2 (wrongly cited as fig. 1 in the plate caption); pl. 5, fig. 3 (lectotype), fig. 4 (syntype).

1983 Renaultia footneri (Marrat) Kidston; Brousmiche, p. 154-158, pl. 37, figs. 1-4a.

T 1992 Renaultia footneri (Marrat) Kidston; Cleal, p. 534, Fig. 9 (lectotype).

v 2010 Renaultia footneri (Marrat) Kidston; Wagner and Álvarez-Vázquez, p. 257, 266.

Description. Frond at least tripinnate. Pinnae of antepenultimate order alternate, subtriangular, always incomplete. Antepenultimate rachis inserted at $80-90^{\circ}$, straight, rounded, longitudinally striate, up to $1 \mathrm{~mm}$ wide. Pinnae of penultimate order alternate, subtriangular, elongate, always incomplete. Penultimate rachis inserted at $75-80^{\circ}$, slightly flexuous, rounded, smooth, up to $0.4 \mathrm{~mm}$ wide. Last order pinnae alternate, distant; subtriangular, elongate, with apical angle of $45-50^{\circ}$. Dimensions: $25-30 \mathrm{~mm}$ long and $15 \mathrm{~mm}$ wide (at the base); length/breadth ratio $=1.6-2$. Last order rachis inserted at $80-90^{\circ}$, slightly flexuous, rounded, smooth, ca. $0.2 \mathrm{~mm}$ wide. Pinnules alternate, decurrent, with a thin, flat lamina. Less developed pinnules inserted at $45-50^{\circ}$ by the entire base, confluent; subtriangular, equilateral, simple or slightly lobed, with a contracted anadromous margin. Well-developed pinnules inserted at $80-90^{\circ}$, subtriangular, composed by three or four pairs of lobes, separated by shallow sinuses and with two to four pointed teeth in each lobe. Dimensions: $4-8 \mathrm{~mm}$ long and $2-4 \mathrm{~mm}$ wide; length/breadth ratio $=2$. Veins deeply embedded in the lamina. Midrib thin, slightly flexuous and strongly marked, remaining well developed to near the apex. The midrib gives off a thin lateral vein to each lobe, once or twice forked at wide angles. Fertile pinnules similar to the vegetative ones. Immature synangia small, oval, placed at the end of lateral veins.

Remarks. Bell (1944, pl. XX, figs. 1-2) figured as Sphenopteris (Renaultia) gracilis a single specimen from Springhill,

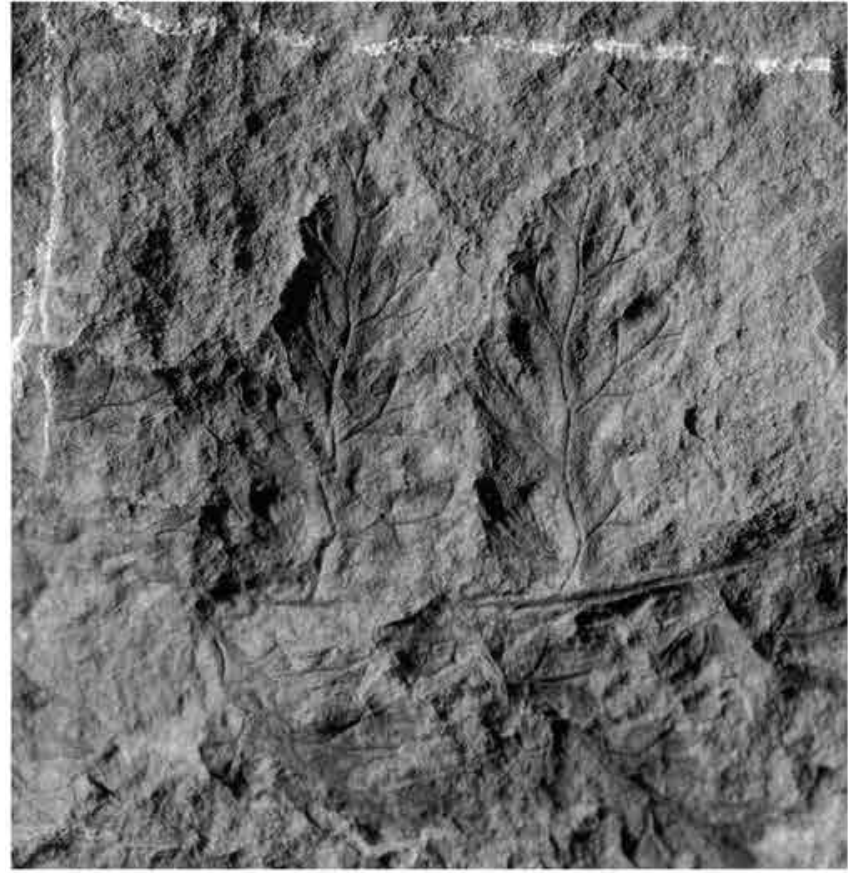

Figure 6. Renaultia footneri $(\times 6)$. GSC 8619. Figured as Sphenopteris (Renaultia) gracilis by Bell (1944, pl. XX, fig. 1 - lower right corner, and fig. 2). Origin: Smith Brook, about 3.2 kilometres from junction with South Branch Black River, Springhill area (locality 1052), Nova Scotia. Repository: Geological Survey of Canada, Ottawa.

Nova Scotia. His illustrations are difficult to evaluate, and later authors consistently ignored Bell's record (e.g., Brousmiche 1983, who discussed Renaultia gracilis in detail but did not refer to the Canadian material). Re-examination of Bell's specimen and comparison with the holotype of Renaultia gracilis (Brongniart 1830, pl. 54, figs. 2a-b), as figured photographically by Brousmiche (1983, pl. 38, figs. 1-1b), suggest that Bell's identification was incorrect. Well-developed pinnules of Renaultia gracilis are subrectangular and composed of three pairs of subangular lobes that are separated by relatively deep sinuses. Bell's (1944) specimen has subtriangular pinnules with three to four pairs of lobes with two to four pointed teeth in each lobe and separated by shallow sinuses. A comparison with type material of Renaultia footneri (Kidston 1889, 1924; Cleal 1981, 1992), suggests that Bell's material belongs to the latter species.

Comparisons. Renaultia gracilis has subrectangular, elongate pinnules, with up to three pairs of more angular lobes. At the same stage of differentiation, pinnules of Renaultia footneri are shorter, with a lower length/breadth ratio. Well-developed pinnules of Renaultia rotundifolia are also subtriangular and composed of three or four pairs of lobes separated by shallow sinuses. However, Renaultia rotundifolia has pinnules that are less elongate, larger, and have a smaller length/breadth ratio. At the same stage of differentiation, pinnules of Renaultia chaerophylloides are larger 
and possess more acute lobes. Both Renaultia footneri and Renaultia chaerophylloides show the first catadromous pinnule smaller than the anadromous one, but in Renaultia chaerophylloides it is markedly smaller and less differentiated. Sphenopteris rutaefolia also possesses subtriangular pinnules, but these are more equidimensional, with a smaller length/breadth ratio. In addition, its pinnule lobes show a more irregular outline and are less deeply incised.

Stratigraphic and geographic distribution. Renaultia footneri is an uncommon species. It ranges from lower Langsettian to upper Bolsovian. The type material is from upper Langsettian strata of the Lancashire coalfield in England. Brousmiche (1983) regarded this species as rare in SaarLorraine, where it ranges from upper Westphalian B to middle Westphalian C (upper Duckmantian to middle Bolsovian).

Occurrence in the Maritime Provinces, Canada. CumberLAND BASIN (Nova Scotia): Bell (1944): locality 1052 (GSC 8619 - together with Corynepteris angustissima and Cordaites sp.).

\section{Renaultia rotundifolia (Andrae 1869) Zeiller 1899}

$$
\text { (Figs. 7a-c, 8a-e) }
$$

*? 1862 Sphenopteris marginata Dawson, p. 321, pl. XV, figs. 38a-b (drawings).

? 1868 Sphenopteris marginata Dawson, p. 551, Fig. 192D (same specimen as Dawson 1862).

* 1869 Sphenopteris rotundifolia Andrae, p. 37, Taf. XII, figs. 1-2a.

? 1871 Sphenopteris marginata Dawson, p. 52, pl. XVI, fig. 184.

? 1888 Sphenopteris marginata Dawson, p. 73, fig. 23D.

$\$ 1899$ Renaultia rotundifolia (Andrae) Zeiller, p. 17.

? 1914 Sphenopteris marginata Dawson (= S. rotundifolia); Stopes, p. 32-33, pl. VIII, fig. 18 (photographic reproduction of Dawson 1871, pl. XVI, fig. 184); pl. VIII, figs. 19-20; text-figs. 1a-b.

1923 Renaultia rotundifolia (Andrae) Zeiller; Kidston, p. 317-319, pl. LXXX, figs. 1-6b.

? 1937 Sphenopteris Laurenti Andrae; Jongmans, p. 407, pl. 27, figs. 74-76.

v 1944 Sphenopteris (Renaultia) rotundifolia (Andrae) Zeiller; Bell, p. 71, pl. XIX; pl. XX, fig. 5 (herein Fig. 7a).

${ }^{*} \mathrm{v} 1944$ Renaultia hydei Bell, p. 72, pl. XX, fig. 4; pl. XXI, figs. 2-6; pl. XXII, fig. 6 (holotype); pl. XXVI, fig. 6.

v 1944 Sphenopteris mixta Schimper; Bell, p. 64, pl. VIII, figs. 1, 3 (see Fig. 8d).

v 1944 Sphenopteris stipulataeformis (Stur) Gothan; Bell, p. 66, pl. XIV, fig. 6 (herein Figs. 7b-c).

1966 Renaultia rotundifolia (Andrae) Zeiller; Bell, p. 14 , pl. VI, fig. 3 .

1980 Sphenopteris cf. hoeninghausi Brongniart; Zodrow and McCandlish, p. 67, pl. 90, figs. 1-2.
T 1983 Renaultia rotundifolia (Andrae) Zeiller; Brousmiche, p. 173-178 (including synonymy), pl. 43, figs. 2-2a (same as Stur 1885, Taf. XLIV, figs. 1,3), fig. 3 (same as Sphenopteris laurentii, Kidston 1923, pl. IX, fig. 1), figs. 4-5a (same as Kidston 1923, pl. LXXX, figs. 2-3), figs. 6-6a (same as Zeiller 1886, pl. IX, fig. 4), figs. 7-7a, figs. 8-8a (neotype), figs. 9-10a; text-figs. 50-51.

v 2010 Renaultia rotundifolia (Andrae) Zeiller; Wagner and Álvarez-Vázquez, p. 257, 266, 268.

2016 Renaultia rotundifolia (Andrae) Zeiller; Opluštil et al., p. 172, fig. 15F.

Description. Frond at least quadripinnate. Broadest visible rachis straight, flat, longitudinally striate, ca. $7 \mathrm{~mm}$ wide. Antepenultimate rachis perpendicularly inserted, straight, flat, longitudinally striate, $2-3 \mathrm{~mm}$ wide. Pinnae of the penultimate order alternate, apparently lanceolate (incomplete), laterally touching or slightly overlapping. Dimensions: up to $70 \mathrm{~mm}$ long and $30 \mathrm{~mm}$ broad. Penultimate rachis perpendicularly inserted, rounded, straight or slightly flexuous, smooth, slender, up to $0.75 \mathrm{~mm}$ wide. Last order pinnae alternate, lanceolate to subtriangular, closely spaced but not touching laterally. Dimensions: $15-40 \mathrm{~mm}$ long and 5-10 $\mathrm{mm}$ broad; length/breadth ratio $=3-4$. Last order rachis inserted at $50-85^{\circ}$, rounded, straight or slightly flexuous, smooth, winged due to fusion of decurrent pinnule bases, slender, up to $0.50 \mathrm{~mm}$ wide. Pinnules alternate, closely spaced, with a relatively thick, convex lamina and undulate margins showing an irregular outline. Less-developed pinnules confluent, ovate, almost entire or very slightly lobed, with a minor contraction on the anadromous side. Dimensions: up to $3 \mathrm{~mm}$ long and $1.6 \mathrm{~mm}$ broad; length/breadth ratio $=1.7-1.8$. Fully developed pinnules shortly stalked, subtriangular, with a symmetrical development of rounded lateral lobes separated by very shallow sinuses. The transition from pinnule to last order pinnae occurs when a fourth pair of lobes is developed. Dimensions: up to $10 \mathrm{~mm}$ long and $6 \mathrm{~mm}$ broad; length/breadth ratio $=1.6$. Veins deeply embedded in the convex lamina. Midrib thin, slightly flexuous and well developed up to near the pinnule apex. Thin lateral veins diverge to each lobe; lateral veins are once to three times dichotomized at a wide angle. Fertile pinnules resembling the vegetative ones, with small, oval and near-marginal sporangia.

Remarks. Bell (1944) figured and described Renaultia rotundifolia on the basis of large pinna fragments displaying thin, rounded rachises and shortly stalked, subtriangular pinnules with rounded lobes; these are fully characteristic of the species. Brousmiche (1983), who described Renaultia rotundifolia in detail and reviewed the literature, accepted Bell's (1944) record.

Bell (1944) introduced a new species, Renaultia hydei, which he compared with Renaultia rotundifolia, but distinguished by its smaller pinnules with a less rounded outline. Bell's specimens are fragmentary and poorly preserved, but I have re-examined the type material of Renaultia hydei and 


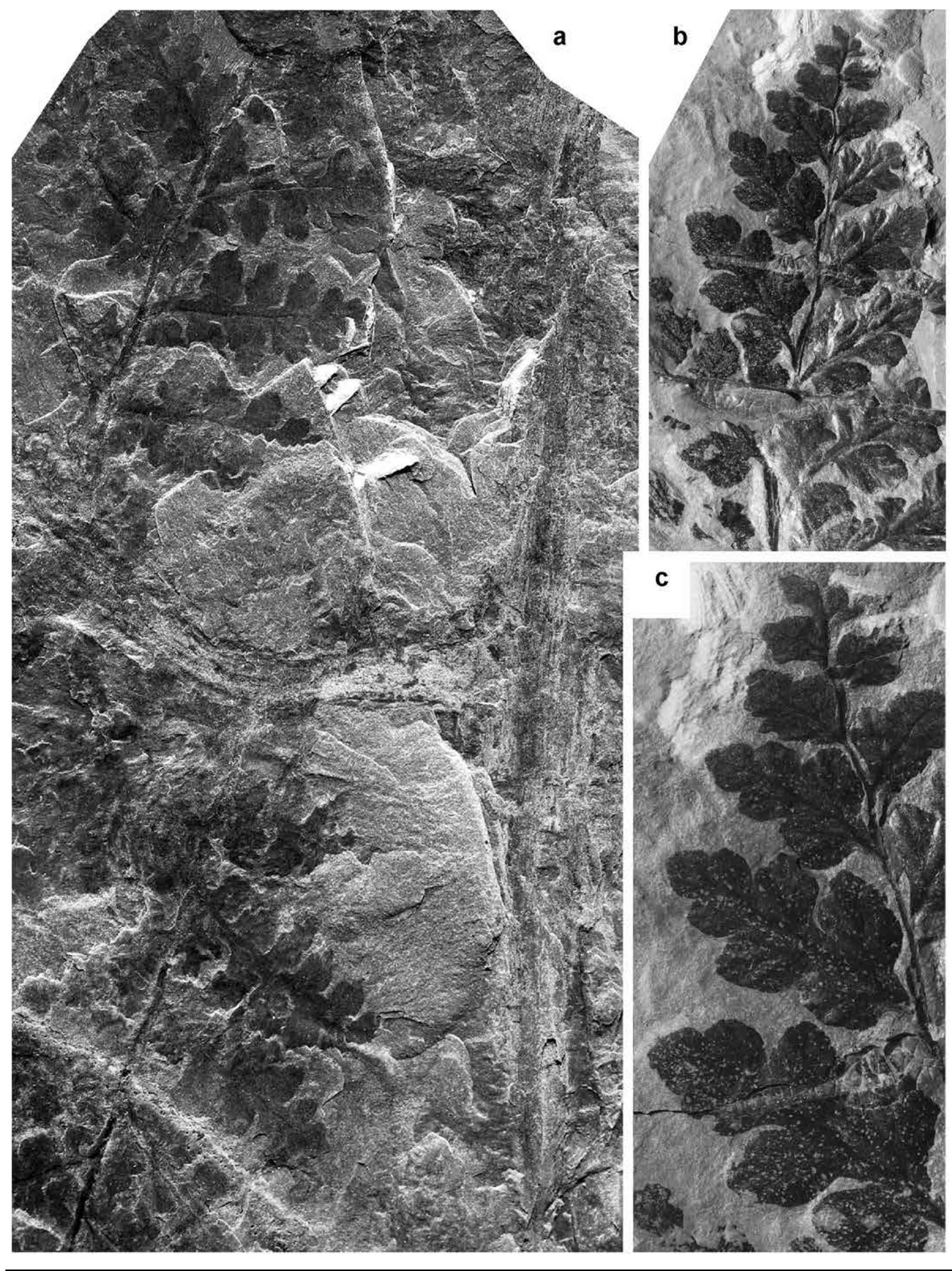


see no evidence for separating this species from Renaultia rotundifolia. One of Bell's specimens (GSC 9374 - Bell 1944, pl. XXI, fig. 3) shows rather small, marginal sporangia that, although poorly preserved, confirm the attribution to Renaultia.

I also include in Renaultia rotundifolia the specimen from Springhill figured as Sphenopteris stipulataeformis by Bell (1944, pl. XIV, fig. 6; see Figs. 7b-c herein). Sphenopteris stipulataeformis is a species based on a single specimen called Oligocarpia? stipulataeformis by Stur (1885, Taf. XXXIII, fig. 5). I regard Stur's species as a pteridosperm, synonymous with Karinopteris obtusifolia.

Finally, the specimen figured as Sphenopteris mixta by Bell (1944, pl. VIII, figs. 1, 3) was excluded by Brousmiche (1983) from her synonymy of Oligocarpia mixta, albeit without comment. This specimen shows closely spaced, shortly stalked, subtriangular, symmetrical pinnules with rounded, entire margins and a convex lamina (see detail in Fig. 8c). It is included here in Renaultia rotundifolia.

It is important to note that most authors, including Bell, accepted Stopes's (1914) opinion that Renaultia rotundifolia is synonymous with Dawson's (1862) poorly defined Sphenopteris marginata. In this case, Sphenopteris marginata would be the name that would have priority. However, the poor quality of Dawson's $(1862,1868)$ schematic illustrations, the small, fragmentary nature of the specimens, and the incomplete description (Dawson 1871) have convinced most authors (e.g., Kidston 1923; Bell 1944; Brousmiche $1983)$ that Andrae's (1869) name, Renaultia rotundifolia, should be preferred, as it is based on more adequate illustrations and more complete description. Only Stopes (1914), who refigured one of Dawson's specimens (Stopes 1914, pl. VIII, fig. 18) and illustrated two additional specimens (her pl. VIII, figs. 19-20) from the Fern Ledges locality at Saint John, insisted on the priority of Dawson's name.

As in the case of Sphenopteris pilosa, I have not been able to review the holotype of Sphenopteris marginata. I have included Dawson's Sphenopteris marginata in the list of synonymy with doubts, waiting the opportunity to review the type. If following review the identity of Sphenopteris marginata and Renaultia rotundifolia is confirmed, the conservation of the name Renaultia rotundifolia should be proposed.

Comparisons. Fully developed pinnules of Renaultia footneri also possess subtriangular pinnules composed of three or four pairs of rounded lobes; however, these are smaller and possess a higher length/breadth ratio than in Renaultia rotundifolia. Renaultia gracilis has smaller, subrectangular pinnules with a straight midrib and up to three pairs of lobes which are separated by deeper sinuses. At the same stage of development, Sphenopteris rutaefolia possesses larger pinnules with a more asymmetrical aspect. Fully developed pinnules are oblong to oblong-lanceolate and composed of three pairs of lobes separated by shallow sinuses. They also show a clearly developed basal lobe that differs from the more symmetric pinnules of Renaultia rotundifolia.

Stratigraphic and geographic distribution. Renaultia rotundifolia is relatively widespread, but never common. The neotype is from the upper Langsettian of the Ruhr District in western Germany. Its total range is from upper Langsettian to lower Asturian, but it seems to characterize Bolsovian strata (Brousmiche 1983).

Occurrence in the Maritime Provinces, Canada. CumberLAND BASIN (Nova Scotia): Bell (1944): locality 77 (GSC 5579 + GSC 9374 - paratypes of Renaultia hydei); locality 999 (GSC 8610 + GSC 8611 - part and counterpart + one piece without catalogue number - together with Sphenophyllum cuneifolium, Calamites sp., Asterophyllites sp. and Lepidostrobophyllum sp.); locality 1070 (GSC 10174 - figured as Sphenopteris stipulataeformis); locality 1082 (GSC 9368); locality 1086 (GSC 10070); locality 1401 (GSC $9382-$ as Renaultia hydei); locality 1406 (GSC 5547 — holotype of Renaultia hydei + GSC 9068 - as Renaultia hydei); locality 1435 (GSC 5571 - as Renaultia hydei); locality 3040 (GSC 5983 - together with Cyperites sp.; figured as Sphenopteris mixta); locality 3115 (two pieces without catalogue number - together with Sphenophyllum cuneifolium and Bowmanites cuneifolius). Donald Reid collection, Joggins, Nova Scotia (1999): DRC-997 55 (together with Cordaites principalis) + DRC-997 56. SAINT John (New BRUnsWICK): Dawson $(1862,1868,1871,1888)$. Stopes (1914). Bell (1944): locality 352 (GSC 119c + GSC 1111 - together with Laveineopteris polymorpha + GSC 15033 + one piece without catalogue number - all labelled as Sphenopteris marginata); locality 804 (GSC 239 - together with Laveineopteris polymorpha + one piece without catalogue number); locality $2254=804$ (nine pieces without catalogue number together with Laveineopteris polymorpha). New BRUnswick Museum collection: Fern Ledges at Saint John, New Brunswick: NBMG 2312 + NBMG 10529 (labelled as Sphenopteris marginata) + NBMG 12046/1; NBMG 12054 (labelled as Sphenopteris marginata). SydNEY BASIN (Nova Scotia): Zodrow and McCandlish (1980).

Occurrence in the United States. West Virginia: Jongmans (1937).

Figure 7. (previous page) (a) Renaultia rotundifolia ( $\times 3)$. GSC 239. Antepenultimate order fragment. Previously figured by Bell (1944, pl. XX, fig. 5). Origin: Fern Ledges at Duck Cove, Saint John, New Brunswick (locality 804). (b) Renaultia rotundifolia $(\times 3)$. GSC 10174. Apical part of penultimate order pinna. Note the relatively thick, convex lamina and weakly lobed margins. Figured as Sphenopteris stipulataeformis by Bell (1944, pl. XIV, fig. 6). Origin: Springhill, mine $\mathrm{n}^{\circ} 7$ (locality 1070), Nova Scotia. (c) Enlargement $(\times 6)$ of part of the specimen in Fig. 6b. Repository: Geological Survey of Canada, Ottawa. 


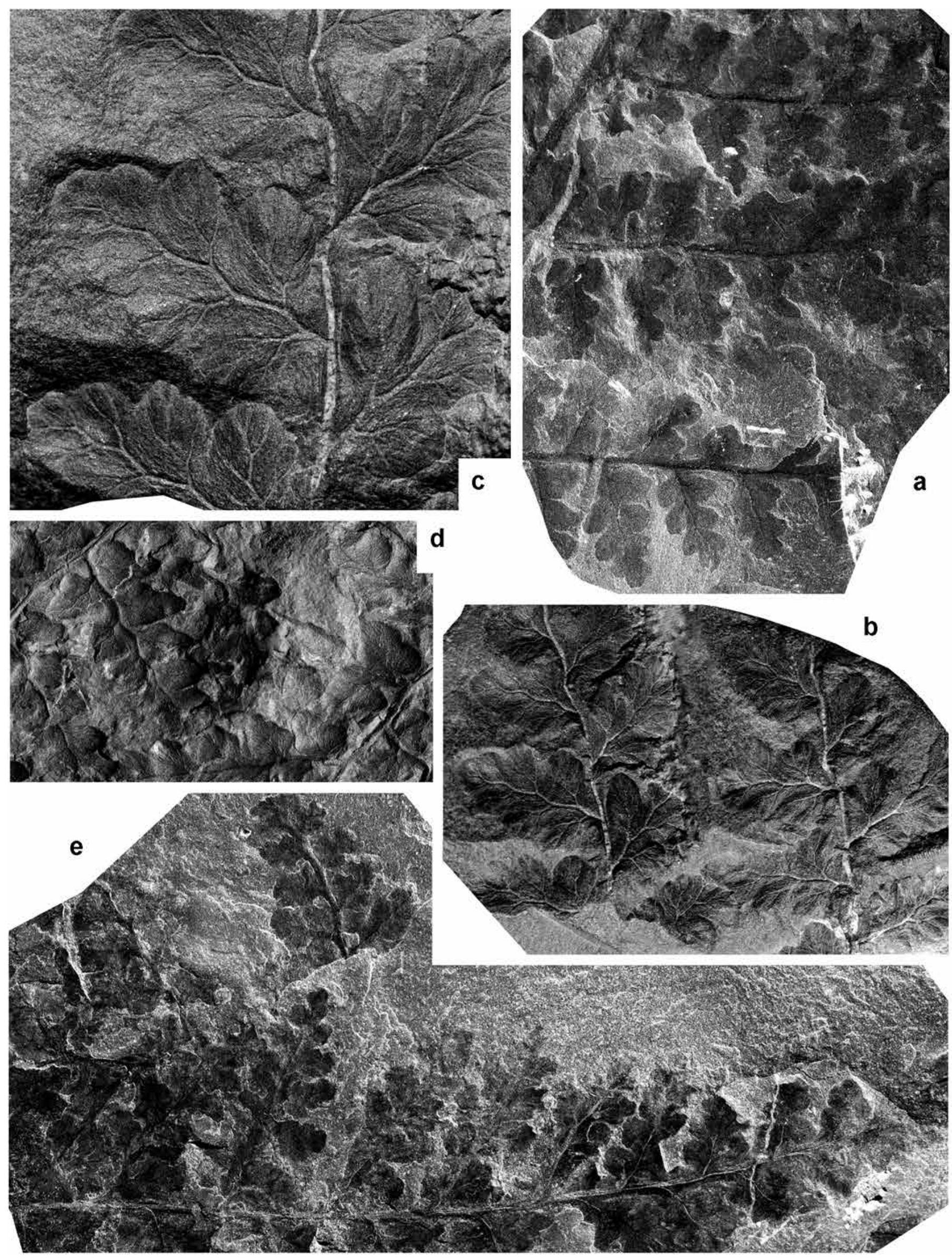


Renaultia schatzlarensis (Stur 1885) Kidston 1890

(Figs. 9a-c)

${ }^{\star} \mathrm{p} 1885$ Hapalopteris Schatzlarensis Stur, p. 58-63, Taf. XXXIX, figs. 7-7a; Taf. XL, figs. 3-6; non Taf. $\mathrm{XL}$, figs. 1-2 (= Boweria schatzlarensis acc. to Frojdová et al. 2017b).

1885 Hapalopteris Aschenborni Stur, p. 63-64, Taf. XXXIX, fig. 6; text-figs. 12a-b (acc. to Gothan 1913).

$\$ 1890$ Renaultia schatzlarensis (Stur) Kidston, p. 32.

* 1914 Sphenopteris deltiformis Kidston, p. 85-86, pl. $\mathrm{X}$, figs. 9-9a.

1923 Sphenopteris (?Renaultia) Schatzlarensis (Stur) Kidston, p. 123-125, pl. XXIX, fig. 4; pl. XXX, figs. 1-1a.

1923 Sphenopteris deltiformis Kidston, p. 106-107, pl. XXII, figs. 2-2a (same as Kidston 1914, pl. X, figs. 9-9a).

p 1938 Sphenopteris cantiana Kidston; Bell, pl. VIII, figs. 2, 3; non p. 25, pl. IX, figs. 1-2 (resembles Eusphenopteris sauveurii).

v 1944 Sphenopteris deltiformis Kidston; Bell, p. 67-68, pl. XV, fig. 2; pl. XVII, fig. 4.

1956 Renaultia schatzlarensis (Stur) Kidston; Danzé, p. 175-181, pl. XXVI, figs. 1-5; text-figs. 9a-c.

v? 1966 Sphenopteris deltiformis Kidston; Bell, p. 12, pl. V, fig. 19 (see Remarks).

v 1966 Sphenopteris (Renaultia) schatzlarensis (Stur) Kidston; Bell, p. 24, pl. XI, fig. 4.

? 1978 Sphenopteris sp.; Gillespie et al., p. 115, 132, pl. 51, fig. 6.

T 1983 Renaultia schatzlarensis (Stur) Kidston; Brousmiche, p. 179-190 (including synonymy), pl. 44, figs. 1-1a (same as Stur 1885, Taf. XL, fig. 4 - lectotype), figs. 2-2c (same as Stur 1885, Taf. XXXIX, fig. 6), figs. 3-4a, figs. 5-5a (same as Sternberg 1821, Taf. XXVI, fig. 5); pl. 45, figs. 1-1b (same as Gothan 1941, Taf. 56, figs. 1-2a), fig. 2, figs. 3-3a (same as Gothan 1913, Taf. 29, fig. 1), figs. 4, 4b (same as Remy and Remy 1959, text-fig. 98), figs. 5-5a, figs. 6-6a (same as Álvarez Ramis et al. 1978, Taf. 11, fig. 5); pl. 46, text-fig. 52C-I text-fig. 53.

p 1985 Zeilleria delicatula Kidston; Gillespie and Crawford, p. 252, pl. II, fig. 3; non pl. II, fig. 4 (= cf.
Zeilleria frenzlii), fig. 5 (= Zeilleria frenzlii).

1989 Zeilleria delicatula Kidston; Gillespie et al., p. 5, 11, pl. 13, fig. 2 (same as Gillespie and Crawford 1985, pl. II, fig. 3).

T 1997 Zeilleria delicatula Kidston; Kvaček and Straková, p. 62, pl. 19, fig. 1 (photograph of holotype).

p 2002 Zeilleria frenzlii (Stur) Kidston; Blake et al., p. 268, 291, pl. XVII, fig. 3; non pl. XVII, fig. 2 (= Zeilleria frenzlii).

v 2010 Renaultia schatzlarensis (Stur) Kidston; Wagner and Álvarez-Vázquez, p. 257, 266.

2011 Sphenopteris delicatula Sternberg; Pšenička \& Opluštil, p. 79-81, pl. X, figs. 5-7; text-figs. 8, 9.

Excludenda:

v 1944 Sphenopteris (Renaultia?) schatzlarensis (Stur) Kidston; Bell, p. 67, pl. XV, figs. 1, 3 (= Sturia amoena).

1967 Sphenopteris schatzlarensis (Stur) Zeiller; Tidwell, p. 29-30, pl. 5, fig. 1 (= Sphenopteris sp. indet. - inadequate illustration, but pinnules are smaller and lobes are more filiform and rounded at the top) (together with Asterophyllites grandis); text-fig. 3C.

1975 Sphenopteris schatzlarensis (Stur) Zeiller; Tidwell, pl. 22, fig. 6 (enlargement of Tidwell 1967, pl. 5, fig. 1; see also pl. 24, fig. 6 of the $19982^{\text {nd }}$ edition of his book).

1966 Sphenopteris sp.; Gillespie et al., p. 104, pl. 32, fig. 3 (difficult to judge from the illustration at natural size, but probably Sturia amoena).

1978 Sphenopteris schatzlarensis (Stur) Zeiller; Gillespie et al., p. 109, 115, 132, pl. 51, fig. 1 (same as Gillespie et al. 1966, pl. 32, fig. 3).

1981 Sphenopteris (?) schatzlarensis (Stur) Zeiller; DiMichele and Dolph, p. 5, pl. 1, Fig. 7 (possibly Crossotheca crepinii).

? 1996 Sphenopteris cf. S. schatzlarensis (Stur) Zeiller; Cross et al., p. 456, fig. 23-19.1 (difficult to judge from the illustration at less than natural size, but maybe Sturia amoena).

2002 Sphenopteris schatzlarensis (Stur) Zeiller; Blake et al., p. 287, pl. VIII, fig. 2 (probably Urnatopteris herbacea).

2002 Sphenopteris (Renaultia) schatzlarensis (Stur)

Figure 8. (previous page) (a) Renaultia rotundifolia $(\times 3)$. Specimen without catalogue number. Labelled as Sphenopteris marginata. Origin: Fern Ledges, Saint John (locality 352), New Brunswick. Repository: Geological Survey of Canada, Ottawa. (b) Renaultia rotundifolia $(\times 3)$. DRC-997-56. Sideritized specimen showing the venation in weakly lobate, fully developed pinnules: a well-developed, thin, slightly flexuous midrib that gives off an equally thin lateral vein to each lobe; veins two or three times dichotomized at a relatively wide angle. Origin: Joggins section (Donald Reid collection), Nova Scotia. Repository: Joggins Fossil Centre, Joggins, Nova Scotia. (c) Enlargement $(\times 6)$ of part of Fig. 8b, showing the vein pattern. (d) Renaultia rotundifolia (× 6). GSC 5983. Detail of the specimen figured as Sphenopteris mixta by Bell (1944, pl. VIII, figs. 1,3) showing the nervation of not fully developed pinnules, and the convex lamina. Origin: Springhill, roof of $\mathrm{n}^{\circ} 2$ coal seam (locality 3040), Nova Scotia. Repository: Geological Survey of Canada, Ottawa. (e) Renaultia rotundifolia (×3). Origin: Fern Ledges, Saint John (locality 2254), New Brunswick. Repository: Geological Survey of Canada, Ottawa. 

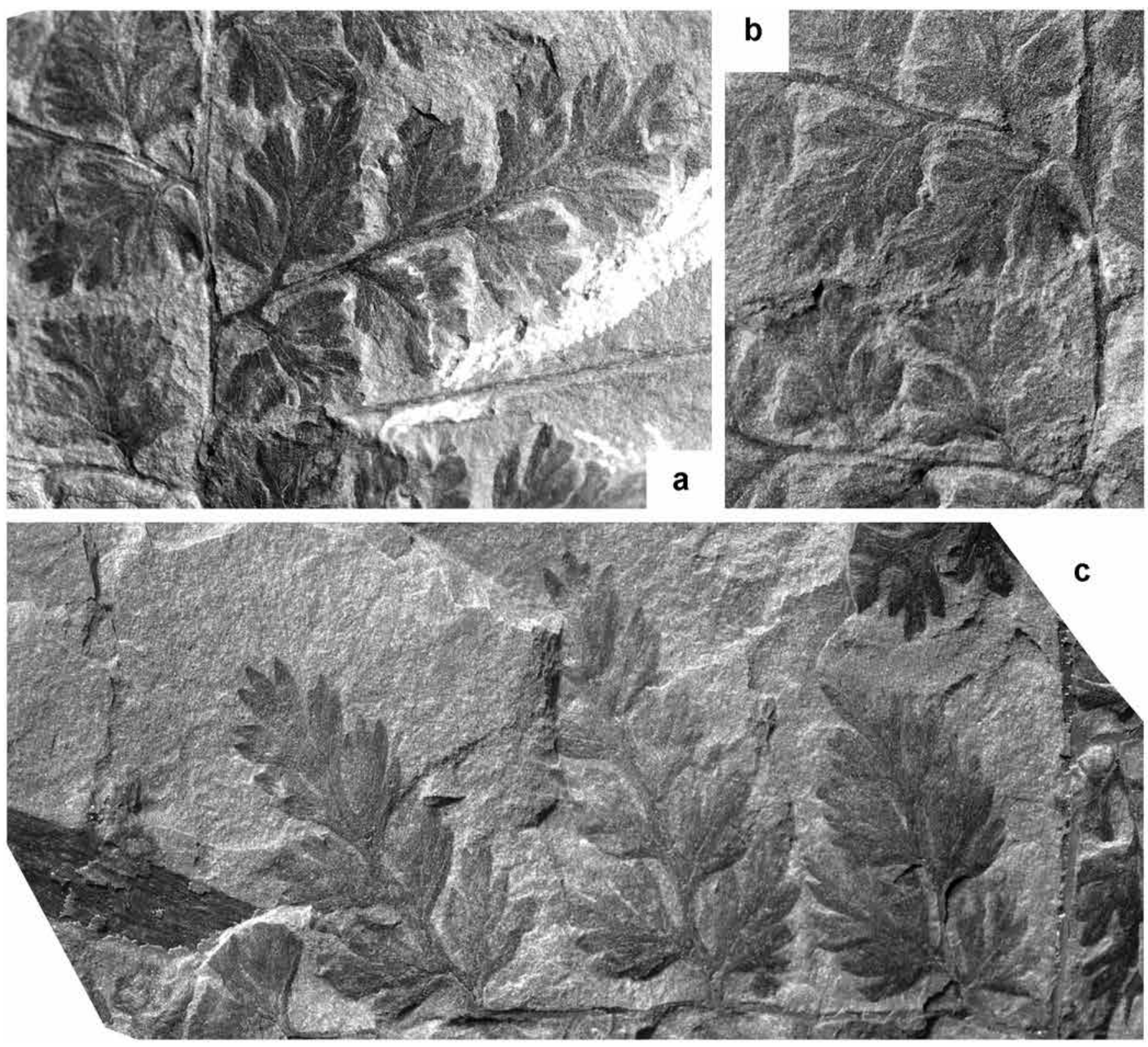

Figure 9. (a) Renaultia schatzlarensis ( $\times 6)$. GSC 9219. Detail of part of the specimen figured by Bell (1944, pl. XV, fig. 2) as Sphenopteris deltiformis. Note the position of stalked pinnules oblique to the rachis, split into simple or bifid, obtusely pointed lobes. Origin: Springhill, no 2 mine, waste dump (locality 1039 - engraved 1069), Nova Scotia. (b) Renaultia schatzlarensis $(\times 6)$. GSC 9219. Another detail of the specimen in Fig. 9a. (c) Renaultia schatzlarensis $(\times 6)$ Specimen without catalogue number from the same locality as Fig. 9a and Fig. 9c. Repository: Geological Survey of Canada, Ottawa.

Kidston; Blake et al., p. 293, pl. XIX, fig. 6 (apparently the same specimen as figured on their pl. VIII, fig. 2, but attributed to a different locality).

Description. Frond at least quadripinnate. Sturdiest visible rachis straight, up to $2.5 \mathrm{~mm}$ wide, longitudinally striate. Pinnae of antepenultimate order alternate, apparently lanceolate (but incomplete). Antepenultimate rachis inserted at $80-90^{\circ}$, rounded, slender, ca. $0.3 \mathrm{~mm}$ wide, slightly flexuous, apparently smooth but longitudinally striate when a carbonaceous lamina is preserved. Pinnae of penultimate order alternate, apparently lanceolate (but incomplete). Penultimate rachis inserted at $80-90^{\circ}$, rounded, ca. $0.25 \mathrm{~mm}$ wide, slightly flexuous, smooth or longitudinally striate when a carbonaceous lamina is present. Last order pinnae alternate, closely spaced but not touching laterally; lanceolate, gradually tapering into a slender terminal, with up to six pairs of pinnules. Dimensions: up to $15 \mathrm{~mm}$ long and $9 \mathrm{~mm}$ wide; length/breadth ratio $\approx 1.7$. Last order rachis inserted at an acute angle, rounded, slightly flexuous, apparently smooth, ca. $0.10-0.15 \mathrm{~mm}$ wide. Pinnules slightly oblique to the rachis, alternate, decurrent, united by a narrow flange in the highest part of pinnae; subtriangular to ovate, with three to 
five deeply incised, spreading, simple or bifid, fairly wide and obtusely pointed lobes. First basal basiscopic pinnule smaller than the basal acroscopic one; apical pinnule reduced to a simple or bifid segment. Dimensions: 7-13 mm long and 3-9 mm wide; length/breadth ratio $=1.4-2.3$. Nervation well-marked in a very thin lamina. Midrib thin, slightly decurrent, sending off individual veins to each lobe.

Remarks. Bell (1966, pl. XI, fig. 4) figured at natural size a magnificent specimen of Sphenopteris schatzlarensis from the Joggins section. Previously, Bell (1944, pl. XV, fig. 2; pl. XVII, fig. 4) had described and figured two other specimens as Sphenopteris deltiformis, a rarely cited species that I regard as synonymous with Renaultia schatzlarensis. Bell (1944, p. 68) did compare Sphenopteris deltiformis with Sphenopteris schatzlarensis but retained the two species separately. When introducing Sphenopteris deltiformis, Kidston (1914) figured only fragmentary specimen (the holotype), which he compared with Sphenopteris bella, a species that Brousmiche (1983) considered synonymous with Sturia amoena. The pinnules of Sturia amoena are smaller and more compact than those of Sphenopteris deltiformis; the latter has pinnules that are more deeply incised and have lobes that are slightly swollen around the middle and end in a relatively blunt point (a deltoid shape according to Kidston).

It is noted that a specimen figured as Sphenopteris bella by Zeiller (1899, pl. I, fig. 13) from the Langsettian of Zonguldak, northern Anatolia (Turkey), was assigned by Kidston (1923, p. 106) to Sphenopteris deltiformis. However, this specimen was referred to Sturia amoena by Brousmiche (1983), an opinion that I share. Sphenopteris deltiformis was reported from Strádonice in Bohemia, Czech Republic, by Němejc (1937), but not illustrated. Neither Kidston nor Němejc compared Sphenopteris deltiformis with Renaultia schatzlarensis, and Sphenopteris deltiformis was not mentioned by Brousmiche (1983).

Bell (1966, pl. V, fig. 19) figured an additional, poorly preserved, specimen from the Fern Ledges at Saint John as Sphenopteris deltiformis. This specimen has rounded rachises bearing small, thin-limbed pinnules with strongly marked veins. Pointed lobes are visible in those places where the outline of pinnules is well preserved. Although this specimen clearly resembles Renaultia schatzlarensis, it also has similarities with Renaultia crepinii. This specimen can only questionably be included in the synonymy of Renaultia schatzlarensis.

Of the two specimens from the Sydney Basin, Nova Scotia, that Bell (1938) figured as Sphenopteris cantiana (a synonym of Sphenopteris schwerinii, according to Brousmiche 1983), one (Bell 1938, pl. VIII, figs. 2-3) is included here in Renaultia schatzlarensis. Although Brousmiche (1983) figured and described Renaultia schatzlarensis exhaustively and discussed its synonymy in detail, she did not mention Bell's record from Nova Scotia. that are generally simple and separated by shallow sinuses, which gives them a more compact appearance than those of Renaultia schatzlarensis. Fertile remains are, of course, quite different. Fully developed pinnules of Zeilleria delicatula are smaller and characterized by three filiform, simple or bifid, spreading lobes. Pinnules of Boweria schatzlarensis are smaller, with three to five rounded lobes attached to the rachis at a single, broad point. Fertile specimens show pinnules with a somewhat reduced lamina and a single sporangium placed at or near the tip of the lobes. Sporangia appear globular rather than ovoid as in Renaultia. Sphenopteris schwerinii has vegetative pinnules with up to three pairs of blunt, less clearly individualized lobes. Also, pinnules are smaller, obliquely inserted, with a markedly decurrent base. Pinnae and pinnules of Sphenopteris bronnii are markedly asymmetric. Well-developed apical growth results in pinnules that are more elongate than those of Renaultia schatzlarensis at the same stage of development.

Stratigraphic and geographic distribution. Renaultia schatzlarensis is a relatively common and widespread, longranging species, from (Yeadonian?) Langsettian to late Asturian. The lectotype is from an indeterminate horizon in the Schatzlar (Žacléř) beds in the Czech part of the IntraSudetic Basin, of early to middle Westphalian age. The holotype of Sphenopteris deltiformis is from the lower Duckmantian of Great Britain. Brousmiche (1983) reported Renaultia schatzlarensis from Saar-Lorraine as particularly frequent in middle Bolsovian to lower Asturian strata.

Occurrence in the Maritime Provinces, Canada. CumBERLANd Basin (Nova Scotia): Bell (1944): locality 1039 (GSC 9445 - together with one specimen figured as Pecopteris (Senftenbergia?) sp., but identified here as Oligocarpia brongniartii + four specimens without catalogue number); locality 1056 (GSC 9273 + GSC 9274 - fragmentary; together with Cyperites sp.); locality 1069 (GSC 9219 - figured as Sphenopteris deltiformis and cited as locality $1039+$ one piece without catalogue number; together with Senftenbergia plumosa); locality 1380 (GSC 10974); locality 2988 (GSC 9220 - figured as Sphenopteris deltiformis); locality 5865 (GSC 15063 — with doubt; see Remarks). Bell (1966): locality 2982 (GSC 15036 - figured as Sphenopteris deltiformis and wrongly cited as coming from locality 352, Saint John, New Brunswick). New Brunswick Museum: NBMG 7237 + NBMG 7239 - poorly preserved specimens, both labelled as Sphenopteris harttii). Sydney Basin (Nova ScoTIA): Bell (1938): locality 513 (GSC 1626 - figured as Sphenopteris cantiana).

Occurrence in the United States. Georgia: Gillespie and Crawford (1985), Gillespie et al. (1989), Blake et al. (2002). Ohio: Cross et al. (1996). West Virginia: Gillespie et al. (1966), Gillespie et al. (1978).

Comparisons. Fully developed pinnules of Sturia amoe$n a$ are smaller, oval, and composed of three pairs of lobes 
Genus Sphyropteris Stur 1883

1883 Sphyropteris Stur, p. 23-24 [655-656].

1885 Sphyropteris Stur, p. 16-18.

1956 Sphyropteris Stur; Danzé, p. 61-62, 261-262.

1983 Sphyropteris Stur; Brousmiche, p. 221-222.

Type. Sphyropteris crepinii Stur 1883.

Remarks. Sphyropteris is easily recognized when its characteristic, transversely oriented sporangiophores, commonly broken off, are preserved; sporangiophores are borne on a narrow expansion at the tip of last order pinnae and pinnules, to which they are placed at right angles. This very rare genus occurs in upper Namurian and lower Westphalian strata. Stur (1883) assigned Sphyropteris to the eusporangiate ferns, which may be correct. However, Kidston (1923) postulated that it could represent the microsporangia of a pteridosperm, an opinion not shared by subsequent authors and not supported by evidence.

\section{Sphyropteris boehnischii Stur 1883}

(Figs. 10a-d)

1883 Sphyropteris Boehnischi Stur, p. 24, 26 [656, 658], text-fig. 7 (drawing).

* 1885 Sphyropteris Boehnischi Stur, p. 17, 24-26, Taf. XXXIX, figs. 3-3a; text-fig. 17 (same as Stur 1883, text-fig. 7).

* 1912 Sphyropteris frankiana Gothan, p. 246, Taf. 5.

? 1913 Sphyropteris cf. Boehnischi Stur; Gothan, p. 132, Taf. 16, fig. 6 (fragmentary).

1923 Sphyropteris aff. Frankiana Gothan; Carpentier, p. 4-6, pl. 10, figs. 1-6.

1923 Sphyropteris cf. tomentosa Stur; Kidston, p. 365-366, pl. LXXXIV, figs. 8-9; text-fig. 31a-b (the fertile specimen described and figured by Kidston shows widely spaced pinnules subdivided into filiform, bluntly pointed lobes. In contrast, Stur's Sphyropteris tomentosa possesses ovate pinnules composed of rounded, shorter and wider lobes with shallow sinuses in between).

1928 Sphenopteris Boehnischi (Sphyropteris) Stur; Šusta, Taf. XX, fig. 4; Taf. XXIII, fig. 4.

1941 Sphenopteris (Sphyropteris) frankiana Gothan; Gothan, p. 22-23, Taf. 57, figs. 1-2a; Taf. 57a, figs. 1-3.

${ }^{*} \mathrm{v} 1944$ Rhodea laqueata n. sp. Bell, p. 58, pl. III, fig. 1 (herein Fig. 10d), fig. 2 (herein Fig. 10a), fig. 3 (herein Fig. 10c), figs. 5-6.

1957 Sphyropteris Frankiana Gothan; Stopa, p. 67, 184, Tab. XXIII, fig. 7.

1966 Rhodea laqueata Bell, p. 12, pl. V, figs. 7-8.

1968 Sphyropteris frankiana Gothan; Kotasowa, p. 50, 86, Tab. XXV, fig. 2.

T 1983 Sphyropteris boehnishii (sic) Stur; Brousmiche, pl. 36, figs. $4-4 b$ (photograph of holotype).
Description. Frond at least bipinnate. Penultimate rachis rounded, smooth, slightly zigzagging, ca. $0.5-0.6 \mathrm{~mm}$ wide. Last order pinnae well-spaced, probably lanceolate (always incomplete). Last order rachis perpendicularly inserted, rounded, smooth and zigzagging, ca. $0.3-0.4 \mathrm{~mm}$ wide. Pinnules widely spaced, inserted at $80-90^{\circ}$; the smaller ones are bifid or reduced to a single, truncate segment; more fully developed ones are composed of three to five bluntly pointed lobes, well spread out, and with an outline parallel to the venation; apical lobe simple or bifid. Dimensions: 3-8 $\mathrm{mm}$ long and 1.5-2.5 $\mathrm{mm}$ wide. Lamina thick, with a rugose surface. Venation not preserved.

Remarks. Bell (1944) figured and described as Rhodea laqueata five fragmentary but distinctive specimens from two localities at Chimney Corner, Cape Breton Island. The loose arrangement of pinnae and the very small, stiff pinnules that are almost devoid of lamina are characteristic. Bell (1944) compared Rhodea laqueata with Rhodea spar$s a$, another form with small pinnules that are composed of parallel-sided ("linear") lobes. However, Rhodea sparsa possesses less geniculate axes and has marks of spines on the rachises. This is in keeping with its probable affinity to $L y$ ginopteris hoeninghausii (Kidston 1923, p. 237). Bell (1944) also compared Rhodea laqueata with Boweria minor (now Kidstoniopteris minor - see Frojdová et al., 2017b), but observed that the pinnule lobes are bluntly pointed in Rhodea laqueata and rounded in Boweria minor.

Comparison of Bell's specimens with more complete and partially fertile material illustrated as Sphyropteris boehnischii by Stur (1885) and Sphenopteris (Sphyropteris) frankiana by Gothan (1941) (the latter being a junior synonym) shows good agreement with regard to pinnae and pinnule morphology and size as well as the stiff "linear" lobes. I consider Sphyropteris boehnischii, Sphyropteris frankiana and Rhodea laqueata to be conspecific.

The generic name Rhodea (= Rhodeopteridium Zimmermann, an illegitimate junior homonym) is commonly applied to bipinnate fronds with pinnules characterized by a narrow, generally stiff lamina that follows the outline of repeatedly forked veins. However, pinnules are not as stiff as in Sphyropteris boehnischii. The type of the genus, a common element of Lower Mississippian floras, is Rhodea stachei, a probable progymnosperm, and not a fern like Sphyropteris. Although Bell's specimens do not preserve the characteristic sporangiate structures, the truncate aspect of some pinnule lobes suggests that the fertile structure has broken off or been shed, suggesting that it belongs to Sphyropteris.

Comparisons. Sphyropteris obliqua has smaller pinnules of oval general outline and a wider lamina with two or three pairs of truncate lobes, the uppermost of which is weakly pointed. Vegetative pinnules of Kidstoniopteris minor are smaller and divided into three narrow, parallel-sided, spreading segments terminated by a rounded apex. Its fertile pinnules are totally different, with sporangia arranged in marginally placed groups. Sphenopteris souichii has also 

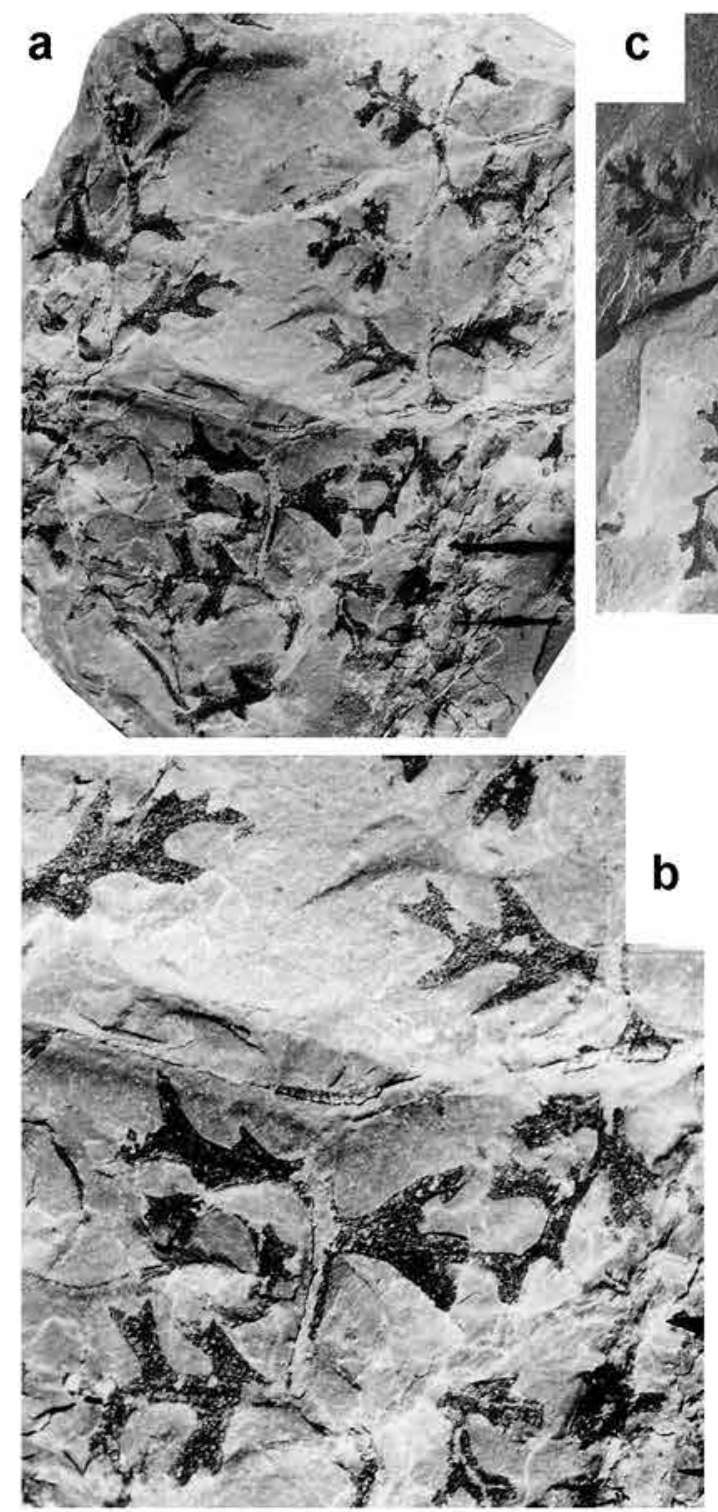
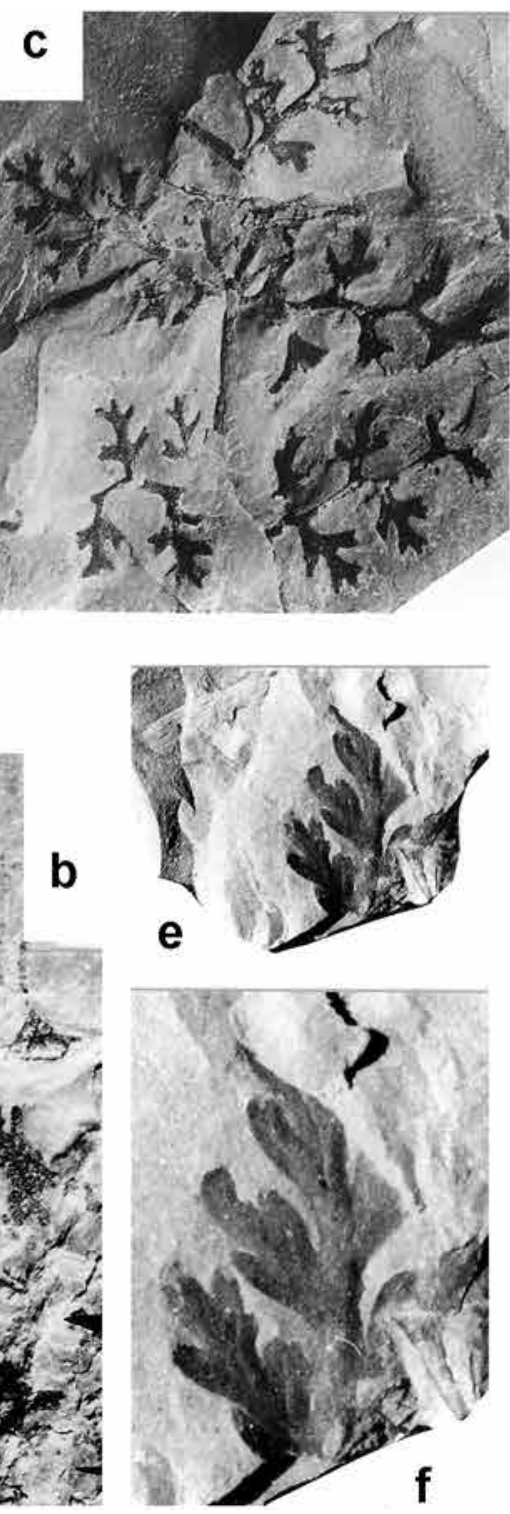
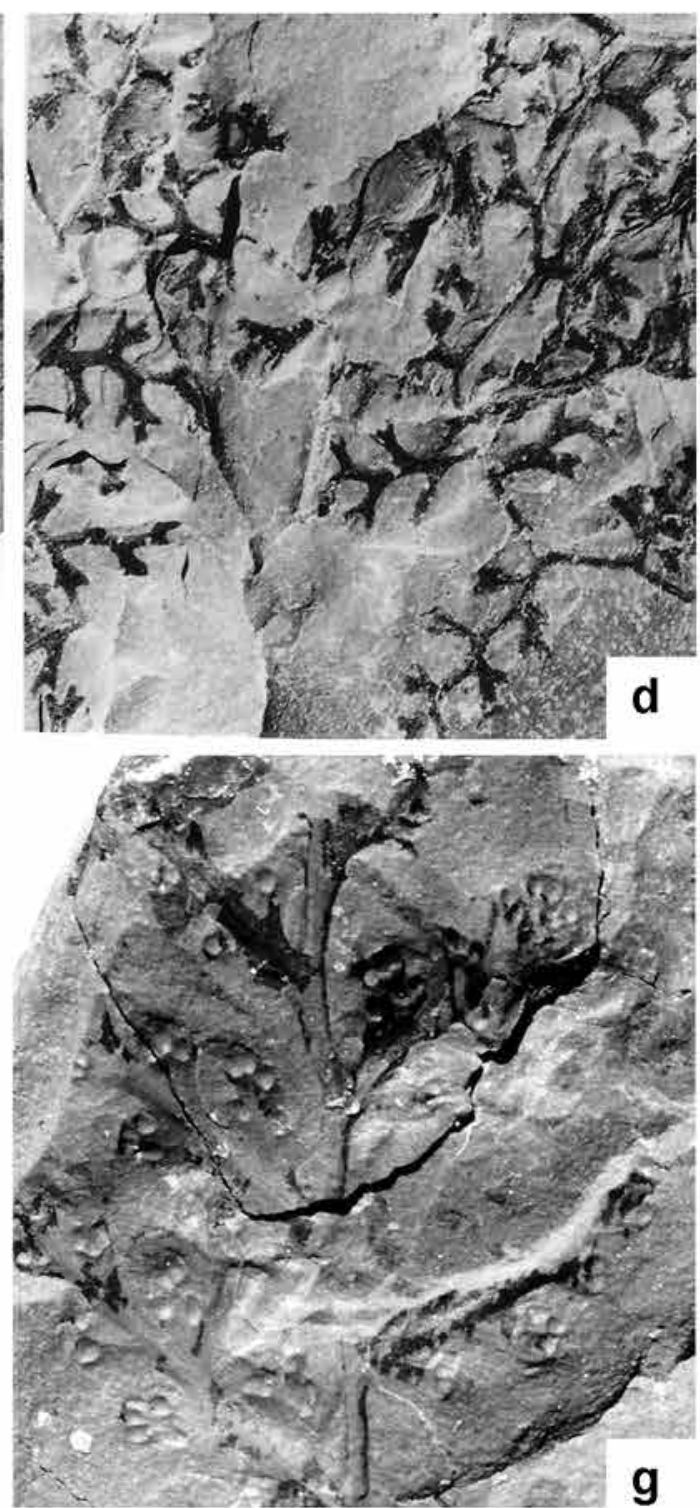

Figure 10. (a) Sphyropteris boehnischii (× 3). GSC 9378. Paratype of Rhodea laqueata (Bell 1944, pl. III, fig. 2). Origin: Chimney Corner area, Inverness County, Nova Scotia, shore about a kilometre north of the old coal mine (locality 1420). (b) Enlargement $(\times 6)$ of part of specimen in 10a. (c) Sphyropteris boehnischii $(\times 3)$. GSC 5942. Detail of another paratype of Rhodea laqueata (Bell 1944, pl. III, fig. 3). Origin: same as for Figs. 10a-b (locality 1420). (d) Sphyropteris boehnischii (×3). GSC 5943. Detail of a further paratype (Bell 1944, pl. III, fig. 1). Origin: same as for Figs. 10a-c (locality 1420). (e) Boweria schatzlarensis ( $\times 1$ 1). GSC 5592. Vegetative pinnules. Previously figured by Bell (1944, pl. XVIII, fig. 3). Origin: Spicer's Cove, from unspecified beds of Fletcher's unit 11 (locality 1386), Nova Scotia. (f) Enlargement $(\times 3)$ of the same specimen. $(\mathrm{g})$ Boweria schatzlarensis $(\times 6)$. GSC 11006. Fertile specimen showing the characteristic small, globular, free sporangia occurring in clusters near the pinnule margin. Previously figured by Bell (1944, pl. XXI, fig. 1). Origin: same as for Figs. 10e-f (locality 1386). Repository: Geological Survey of Canada, Ottawa.

vegetative pinnules of uniform size and a narrow lamina following the venation; however, the pinnules are more closely arranged and have rounded lobes and straight, non-flexusous rachises with a fine longitudinal striation. Although Zeiller (1888) compared his Sphenopteris souichii with Sphyropteris (Sphyropteris boehnischii in particular), no fertile structures of Sphenopteris souichii have yet been recorded.
Stratigraphic and geographic distribution. Sphyropteris boehnischii is rarely cited. The holotype is from the lower to middle Westphalian of the Schatzlarer Schichten in the Intra-Sudetic Basin, Czech Republic. Šusta (1928) recorded Sphyropteris boehnischii from Westphalian A and B (Langsettian and Duckmantian) of the Karviner Schichten, in Moravia/Upper Silesia (Czech Republic and Poland). Gothan $(1912,1941)$ recorded Sphyropteris frankiana from the Westphalian A (Langsettian) of the Ruhr District, western 
Germany. Stopa (1957) and Kotasowa (1968) figured it from the Westphalian A (Langsettian) of the Upper Silesian Basin in Poland. Carpentier's (1923) material came from Westphalian B (Duckmantian) strata of Nord/Pas-de-Calais, France.

Occurrence in the Maritime Provinces, Canada. CumberLAND BASIN (Nova Scotia): Bell (1944): locality 1416 (GSC 5673); locality 1420 (GSC 5942 + GSC 5943 - holotype of Rhodea laqueata + GSC 9366 + GSC 9378). Bell (1966): locality 1420 (GSC 15046).

\section{Family incertae sedis}

Genus Boweria Kidston 1911

1911 Boweria Kidston, p. 31-34.

1923 Boweria Kidston, p. 291-292.

1956 Boweria Kidston; Danzé, p. 77-78, 363-365.

1986 Boweria Kidston; Brousmiche, p. 232.

2017b Boweria Kidston; Frojdová et al., p. 36-47.

Type. Boweria schatzlarensis Kidston 1911.

Remarks. Boweria is characterized by free circular to oval sporangia that occur in clusters at vein extremities, near to or at the pinnule margin. Fertile pinnules show a slightly reduced lamina in comparision with vegetative ones. The systematic position of Boweria is still uncertain, although it is generally regarded to be a leptosporangiate fern. Kidston (1911) designated Hapalopteris schatzlarensis, from lower Westphalian strata in the Intra-Sudetic Basin (Stur 1885), as type. Boweria is a rarely cited genus. The few available records are all from lower to middle Westphalian strata. The genus comprises only two species: Boweria schatzlarensis and Boweria nowarudensis. Frojdová et al. (2017b) transferred Boweria minor to Kidstoniopteris, a genus with shorter, grouped sporangia and a semi-equatorial annulus.

\section{Boweria schatzlarensis Kidston 1911}

(Figs. 10e-g)

* p 1885 Hapalopteris Schatzlarensis Stur, Taf. XL, fig. 1 (lectotype as designated by Frojdová et al. 2017b), fig. 2; non p. 58-63, Taf. XXXIX, figs. 7-7a (= Renaultia schatzlarensis); Taf. XL, figs. 3-6 (= Renaultia schatzlarensis); text-fig. 11 (= Renaultia schatzlarensis) (acc. to Brousmiche 1983).

1911 Boweria Schatzlarensis Kidston, p. 31-34, Fig. 5; Fig. 6A-C (drawings of sporangia).

1923 Boweria Schatzlarensis Kidston, p. 292-294, pl. LXXI, figs. 1-6.

? p 1938 Boweria schatzlarensis Kidston; Bell, p. 40-41, pl. XXVI, figs. 2-3 (difficult to judge from the illustrations); non pl. XXVIII, figs. 1-2 (difficult to judge, but resembling Renaultia).

v 1944 Boweria schatzlarensis Kidston; Bell, p. 71, pl. XVIII, fig. 3 (herein Figs. 10e-f); pl. XXI, fig. 1 (herein Fig. 10g).
1956 Boweria schatzlarensis Kidston; Danzé, p. 365-370, pl. LX, figs. 1-3a; text-figs. 32a-d.

1986 Boweria schatzlarensis Kidston; Brousmiche, $p$. 232-233, pl. I, figs. 1-1a (same as Kidston 1923, pl. LXXI, figs. 3, 4), fig. $1 \mathrm{~b}$ (sporangia), figs. $1 \mathrm{c}-1 \mathrm{~g}$ (spores); pl. I, figs. 3-5; pl. 1, figs. 5a-5c (spores).

1991 Sphenopteris (Boweria) schatzlarensis (Kidston) Jongmans; Josten, p. 214-215, Taf. 97, figs. 3-3a; Abb. 134.

T k 2017b Boweria schatzlarensis Kidston; Frojdová et al., p. 37-43, pl. I, figs. 1-2 (lectotype), figs. 3-7; pl. II, fig. 1, figs. 2-7 (cuticles); pl. III, figs. 1-4; pl. IV, figs. 1-5; pl. V, figs. 1-8 (sporangia); pl. VI, figs. 1-4 (spores); text-figs. 4-9 (drawings).

Description and remarks. Bell (1944) figured as Boweria schatzlarensis two small fragments, one representing vegetative remains and the other fertile remains. Both specimens are well illustrated and come from locality 1386, in the upper part of the Joggins section in Nova Scotia. The vegetative fragment (Bell 1944, pl. XVIII, fig. 3 - Figs. 10e-f herein) shows only six incomplete pinnules in near-terminal position in a last order pinna. These pinnules are obliquely inserted, decurrent, and attached to the rachis at a single, rather broad point; they consist of three to five rounded lobes. The fertile specimen (Bell 1944, pl. XXI, fig. 1 - Fig. 10g herein) shows pinnules with a somewhat reduced lamina and apparently single sporangia placed in a marginal position. This accords well with the sporangia of Boweria schatzlarensis figured by Kidston (1923, pl. LXXI, fig. 3a), Brousmiche (1986, pl. I, figs. 1-1a) and Frojdová et al. (2017b, pl. IV, figs. 2, 3). Sporangia appear globular rather than ovoid, which suggests affinity with Boweria rather than with Renaultia. However, the absence of a visible annulus makes a clear assignment problematic. Sporangia of Boweria schatzlarensis are characterized by a prominent annulus, whereas Renaultia has exannulate sporangia. Kidston (1923) recorded the presence of a single sporangium near the tip of each pinnule lobe.

Comparisons. Boweria nowarudensis has smaller, more deeply incised, lobate pinnules of elongate ovoid shape, with five to seven lobes showing bluntly rounded sub-lobes. Vegetative pinnules of Kidstoniopteris minor are smaller and divided into more filiform, rounded or slightly pointed, spreading segments; its fertile pinnules are practically devoid of lamina, with the short-stalked sporangia either solitary or irregularly grouped on the pinnule margin (Frojdová et al., 2017b).

Stratigraphic and geographic distribution. Boweria schatzlarensis has been recorded only occasionally. According to Frojdová et al. (2017b) the type material is from Langsettian-Duckmantian strata (Lower Moscovian) of the Ruhr Basin, western Germany. Josten (1991) noted that this species occurs sporadically in the upper Westphalian A and 
Westphalian B (upper Langsettian and Duckmantian) of western Germany. It has been recorded from Duckmantian strata of Great Britain by Kidston (1923). Danzé (1956) and Brousmiche (1986) noted that its range extended into lower Westphalian C (lower Bolsovian) strata.

Occurrence in the Maritime Provinces, Canada. CumBERLAND BASIN (Nova Scotia): Bell (1944): locality 1386 (GSC 5592 + GSC 11006). Sydney Basin (Nova Scotia): Bell (1938): locality 727 (GSC 2924 — with doubt); locality 989 (GSC 8398 — with doubt).

Genus Germera Brousmiche 1983

1983 Germera Brousmiche, p. 225-226.

Type. Germera mendescorreae (Teixeira 1939) Brousmiche 1983.

Remarks. The genus Germera has fertile and vegetative pinnules that are identical to each other in general aspect. Fertile pinnules are characterized by eusporangiate sori placed in apical position; sporangia are short, ovoid, 20-26 in number, and inserted on an oblong receptacle, in pendent position below the lamina. Spores are unknown.

\section{Germera brousmicheae sp. nov.}

(Fig. 11c)

* 1975 Sphenopteris digitata Doubinger; Doubinger and Germer, p. 375, pl. I, fig. 3 (wrongly cited as fig. 2).

1978 Sphenopteris (Zeilleria) delicatula Kidston; Âlvarez-Ramis et al., p. 17, Taf. 8, figs. 1-2; Abb. 27 (included in Germera mendescorreae by Brousmiche 1983).

T 1978 Sphenopteris digitata Doubinger; ÁlvarezRamis et al., p. 17-18, Taf. 8, figs. 3-4 (same as Doubinger and Germer 1975); Abb. 28.

T p 1983 Germera mendescorreae (Teixeira) Brousmiche, p. 227-233, pl. 55, figs. 1-1e (same as Doubinger and Germer 1975, pl. I, fig. 3, and Álvarez-Ramis et al. 1978, Taf. 8, fig. 3), figs. 2, 4-5; pl. 56, figs. 1-1a, figs. 2-2a (same as Álvarez-Ramis et al. 1978, Taf. 8, figs. 1-2), figs. 3-7c; non pl. 55, figs. 3-3b (topotype of Sphenopteris mendescorreae).

v 1995 Germera cf. mendescorreae (Teixeira) Brousmiche; Âlvarez-Vázquez, p. 181-183, lám. 61, figs. 1-5.

v 1999 Germera cf. mendescorreae (Teixeira) Brousmiche; Álvarez-Vázquez, p. 44, fig. 4 (name only).

v 2010 Germera cf. mendescorreae (Teixeira) Brousmiche; Wagner and Álvarez-Vázquez, p. 266, 316.

Holotype. Specimen figured and described as Sphenopteris digitata in Doubinger and Germer (1975, p. 375, pl. I, fig. 3); Álvarez Ramis et al. (1978, p. 17-18, Taf. 8, figs. 3-4, Abb.
28); and refigured as Germera mendescorreae by Brousmiche (1983, pl. 55, figs. 1-1e). Collection: Saarbergwerke in Saarbrücken, western Germany, n C/7440.

Derivation of name. After Claudine Brousmiche, in recognition of her significant contribution to the knowledge of sphenopterid ferns of the Carboniferous.

Type locality, horizon and age. Hailigenwald Formation, Saarbrucken Group, Saarland, western Germany; Bolsovianearly Asturian.

Diagnosis. Less developed pinnules tongue-shaped, decurrent on catadromous side; alternate differentation of lobes and apical development predominant; lobes sturdy, with rounded or tongue-shaped apices; pinnules asymmetric due to early division of basal anadromous lobe; catadromous basal lobe generally simple; pinnules fully developed at the stage of development of the fourth pair of lobes. Fertile pinnules of identical shape to vegetative ones, with fertile structure of Germera-type. (Shortened from the freely translated French decription of the material cited as Germera mendescorreae by Brousmiche 1983, p. 227.)

Description. Frond at least bipinnate. Pinnae of the antepenultimate order closely spaced, apparently lanceolate (always incomplete). Dimensions: up to $40 \mathrm{~mm}$ long and $22 \mathrm{~mm}$ wide. Last order rachis straight, rounded, finely striate longitudinally, ca. $0.6-0.7 \mathrm{~mm}$ wide. Last order pinnae alternate, closely spaced and touching at their margins; subtriangular, slightly asymmetric, and tapering gradually into a small, filiform, apical segment that is partially fused with the nearest contiguous pinnules. Dimensions: $10-15 \mathrm{~mm}$ long and $8-9 \mathrm{~mm}$ wide; length/breadth ratio $=1.25-1.65$. Last order rachis straight, flat, winged, finely striate longitudinally, ca. $0.4-0.5 \mathrm{~mm}$ wide. Pinnules alternate, closely spaced, inserted at $45-50^{\circ}$, and consisting of up to three pairs of closely adpressed, parallel-sided, elongate lobes; pinnules show a decurrent base and a rounded apex. Dimensions: 4-9 mm long and $1.5-3 \mathrm{~mm}$ wide; length $/$ breadth ratio $=2.6-3$. Lamina thin, of delicate appearance. Venation consists of a thin midrib with lateral veins at a wide angle, sending off one lateral vein to each lobe.

Remarks. This species, here recorded for the first time from Canada, is represented by three specimens from Spicer's Cove (collection of Fundy Geological Museum, Parrsboro).

The generic name Germera was established by Brousmiche $(1983$, p. 225$)$ for the reproductive structures of a partially fertile specimen that had been illustrated under the name Sphenopteris digitata by Doubinger and Germer (1975, pl. I, fig. 3) and Álvarez-Ramis et al. (1978, Taf. 8, figs. 3-4). Brousmiche (1983) included this specimen, which comes from upper Westphalian strata of Saar-Lorraine, in Germera mendescorreae. Subsequently, specimens from lower Bolsovian strata of the Peñarroya-Belmez-Espiel coalfield, southwestern Spain, were recorded as Germera cf. 

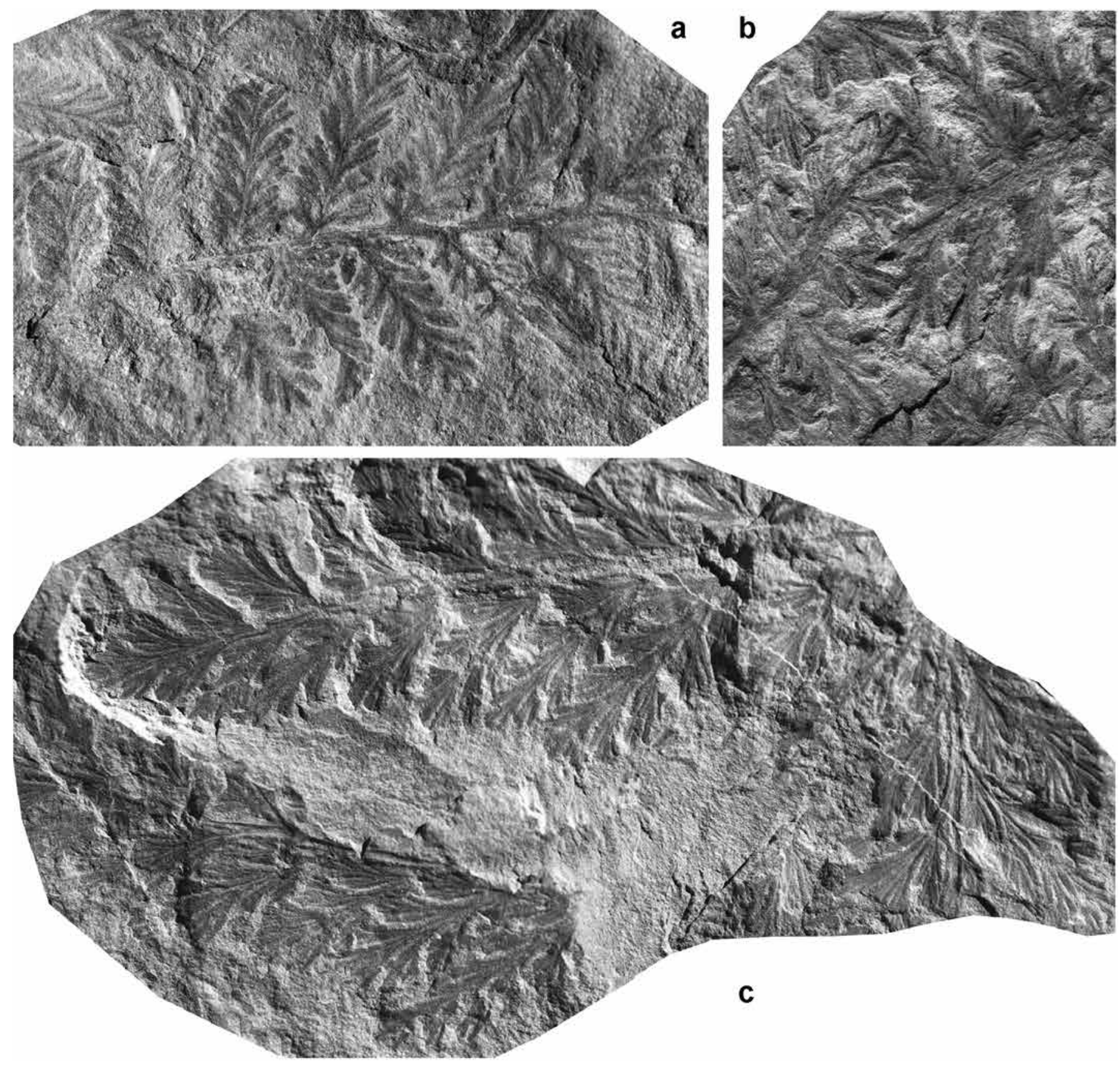

Figure 11. (a) Sphenopteris sampaiana $(\times 3)$. Previously figured by Teixeira (1939, Est. IX, figs. 1-1a). Origin: $50 \mathrm{~m}$ west of Mirante da Bela, Ermezinde, Douro Basin, Portugal. (b) Germera mendescorreae $(\times 3)$. Left part of the specimen figured as Sphenopteris Mendes-Correae by Teixeira (1939, Est. XI, fig. 3). Origin: Mirante da Bela, Ermezinde, Douro Basin, Portugal. Repository: Museu Wenceslau de Lima, Faculdade de Ciências, Universidade do Porto, Portugal. (c) Germera brousmicheae $(\times 3)$. FGM 999 GF 13.9/21.2. Specimen showing the thin, delicate lamina, and closely adpressed, parallel-sided, elongate lobes, with rounded apex that are characteristic of the species. Origin: Spicer's Cove, Nova Scotia. Repository: Fundy Geological Museum, Parrsboro, Nova Scotia.

mendescorreae by Álvarez-Vázquez $(1995,1999)$ and Wagner and Álvarez-Vázquez (2010).

The species name Sphenopteris digitata, as first used by Doubinger (1959, p. 114), was published without a diagnosis or illustrations. Vetter (1968, pl. XL, figs. 5-6), ÁlvarezRamis and Doubinger (1973, pl. 1, figs. 1-1a), and Boureau and Doubinger (1975, figs. 443A, B) figured the cited spec- imen at a later date. This specimen came from Stephanian strata in the Saint-Perdoux Basin, Lot, southern France. It is a small fragment of penultimate order pinna showing small pinnules with two or three pairs of short, filiform lobes, a decurrent base and a rounded apex.

Brousmiche (1983) accepted both that the Westphalian material of Germera from Saar-Lorraine was conspecific 
with the Portuguese species Sphenopteris mendescorreae, and the synonymy between Teixeira's species Sphenopteris mendescorreae and Sphenopteris sampaiana, as proposed by Wagner and Lemos de Sousa (1983). Both Sphenopteris mendescorreae and Sphenopteris sampaiana were described by Teixeira (1939) from Stephanian C strata in the Douro Basin, northern Portugal. Álvarez-Vázquez (1995) refigured a number of syntypes of Sphenopteris mendescorreae and Sphenopteris sampaiana and noted that pinnules of Sphenopteris sampaiana retain the same size throughout the pinna and are characterized by stiff, simple or bifid lobes with acute apices (see Fig. 11a herein). In contrast, Germera mendescorreae (originally Sphenopteris mendescorreae) possesses more spreading pinnules, constituted by filiform, parallel-sided lobes with more rounded apices (Fig. 11b). Germera mendescorreae and Sphenopteris sampaiana are thus separate species.

As pointed out by Álvarez-Vázquez (1995) and Wagner and Álvarez-Vázquez (2010, p. 316), the Westphalian specimens from Saar-Lorraine attributed to Germera mendescorreae by Brousmiche (1983) actually represent a different species of Germera, described here as Germera brousmicheae sp. nov.

Comparisons. Germera mendescorreae has pinnules that are more spaced-out and of smaller size and lower length/ breadth ratio than those of Germera brousmicheae. Fully developed, vegetative pinnules of Zeilleria frenzlii, although similar in size to those of Germera brousmicheae, possess larger, more spread-out lobes with acute apices. Also, the reproductive structures of Zeilleria differ from those of Germera. Pinnules of Sphenopteris sampaiana retain the same size throughout the pinna and possess stiff, simple or bifid lobes with acute apices

Stratigraphic and geographic distribution. Germera brousmicheae is known only from a few localities, insufficient to establish a stratigraphic range. The specimens described by Brousmiche (1983) from Saar-Lorraine are from upper Bolsovian to upper Asturian strata. Álvarez-Vázquez (1995, 1999) and Wagner and Álvarez-Vázquez (2010) recorded material from lower Bolsovian strata in the Peñarroya Basin of southwestern Spain.

Occurrence in the Maritime Provinces, Canada. Cumberland Basin (Nova Scotia): Fundy Geological Museum: FGM 999 GF 13.8/21.2 + FGM 999 GF 13.9/21.2 (together with Dorycordaites palmaeformis and rootlets) + FGM 997 GF 31.7 (fragmentary - together with Dorycordaites palmaeformis).

Order Filicales Copeland 1947

Family Sermayaceae Eggert and Delevoryas 1967

Genus Oligocarpia Göppert 1841

1841 Oligocarpia Göppert, p. 35.

1883 Oligocarpia Göppert; Stur, p. 54 [686].
1954 Oligocarpia Göppert; Abbott, p. 40-44.

1956 Oligocarpia Göppert; Danzé, p. 48-50, 289-292.

1983 Oligocarpia Göppert; Brousmiche, p. 234-235.

Type. Oligocarpia gutbieri Göppert 1841.

Remarks. Fertile pinnules of Oligocarpia are characterized by circular sori attached to the abaxial side of pinnules; each sorus is composed of three to thirty subspherical to pyriform, stalked sporangia showing a prominent annulus consisting of two rows of thick-walled cells. Individual sori cover lateral veins; most often these are sufficiently large to occupy the entire space between midrib and margin of the (slightly reduced) pinnule lamina; if not they are situated near the margin. Vegetative pinnules are either sphenopteroid or pecopteroid, and similar in shape to the fertile ones, with similar or a slightly smaller size. Oligocarpia is a relatively common genus with several species. It occurs widely in Westphalian as well as Stephanian strata.

\section{Oligocarpia brongniartii Stur 1883}

(Figs. 12a-b)

*? 1871 Sphenopteris splendens Dawson, p. 53, pl. XVI, figs. 186-186a (diagrammatic drawings - see Remarks).

1883 Oligocarpia brongniarti Stur, p. 56 [688], Figs. 16a-c (see Stopes 1914).

* 1885 Oligocarpia Brongniarti Stur, p. 131-134, Taf. LVII, figs. 2-3; text-fig. 20.

? 1914 Oligocarpia splendens (Dawson) Stopes, $\mathrm{p}$. $40-41$, pl. X, fig. 24 (photograph of holotype); text-fig. 4 (drawing).

1938 Oligocarpia brongniarti Stur; Bell, p. 42-43, pl. XXIX; pl. XXX, figs. 1-2.

v 1944 Oligocarpia brongniarti Stur; Bell, p. 76, pl. XXV, figs. 2, 4 (poorly preserved).

v 1944 Pecopteris (Senftenbergia?) sp.; Bell, p. 86, pl. XLII, figs. 2, 4 (herein Figs. 12a-b).

1954 Oligocarpia brongniarti Stur; Abbott, p. 49-51, figs. 6-12 (drawings), 17-19b (drawings of sporangia and sori).

1962 Oligocarpia brongniarti Stur; Bell, p. 15-16, pl. I, fig. 3.

1966 Oligocarpia brongniarti Stur; Bell, p. 40, pl. XIX, fig. 4.

T 1983 Oligocarpia brongniartii Stur; Brousmiche, p. 245-249, pl. 62, figs. 1-4; pl. 63, figs. 1-1f (neotype), fig. 2; pl. 64, figs. 1-3.

Description. Frond at least bipinnate. Penultimate rachis straight, rounded, ca. $0.25 \mathrm{~mm}$ wide. Last order pinna alternate, lanceolate, inserted at $45-50^{\circ}$. Dimensions: up to $12 \mathrm{~mm}$ long and $4 \mathrm{~mm}$ wide at the base; length/breadth ratio $=3$. Last order rachis straight, rounded, ca. $0.1 \mathrm{~mm}$ wide. Pinnules alternate, oblique, ovate, slightly contracted at the base with a narrow sinus or attached by their entire width (pecopteroid aspect); decurrent, with slightly lobate or toothed margins; 

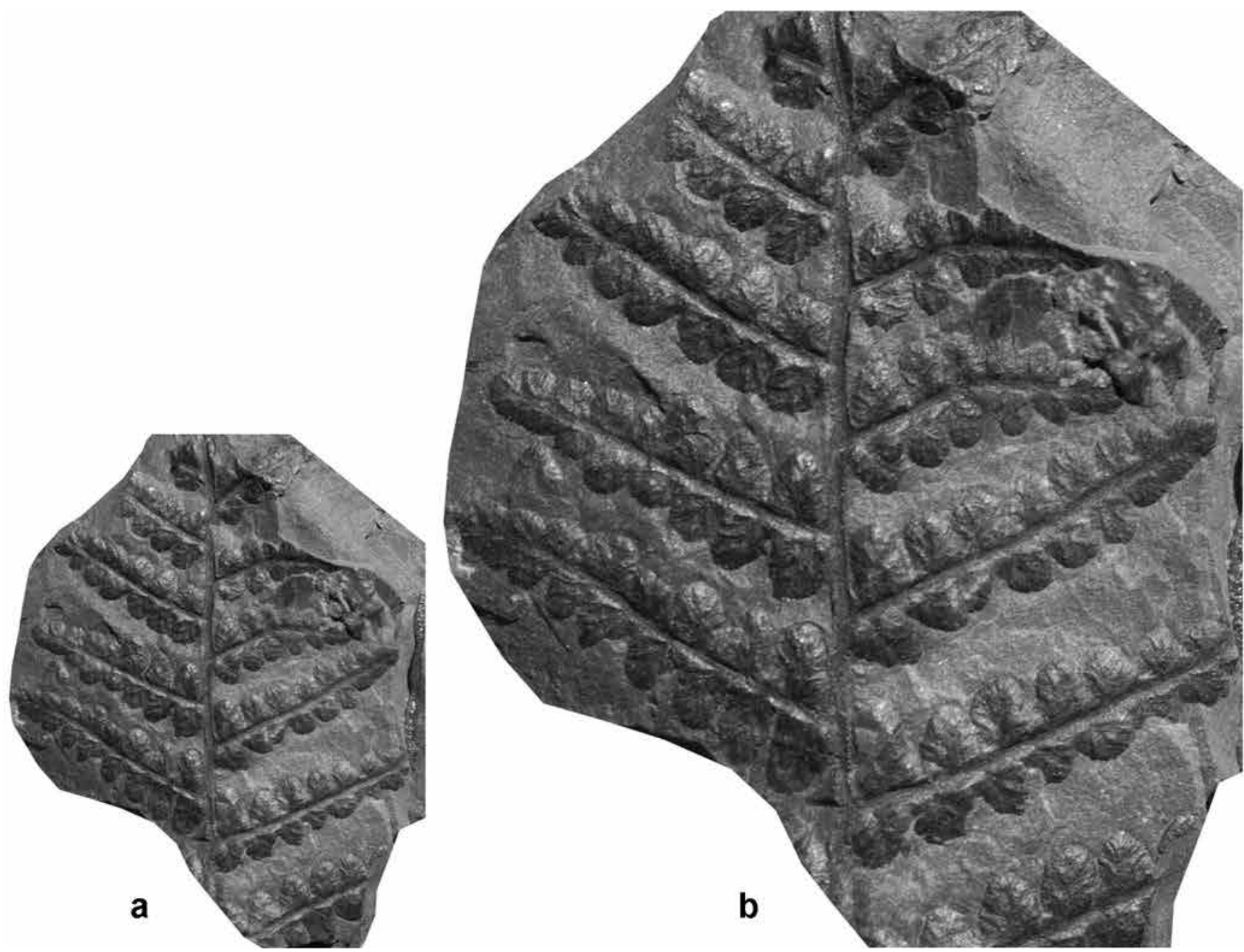

Figure 12. (a) Oligocarpia brongniartii ( $\times 3$ ). Penultimate pinna fragment previously figured as Pecopteris (Senftenbergia?) sp. by Bell (1944, pl. XLII, figs. 2, 4). Origin: Springhill, $\mathrm{n}^{\circ} 2$ mine, waste dump (locality 1039), Nova Scotia. (b) Enlargement $(\times 6)$ of specimen in 12a. Repository: Geological Survey of Canada, Ottawa.

terminal subcircular, very short. Dimensions: $1-2 \mathrm{~mm}$ long and $0.5-1 \mathrm{~mm}$ wide; length $/$ breadth ratio $=0.5-2$. Lamina relatively thick. Venation well-marked, showing a distinct, relatively wide, flexuous midrib, giving off a single vein to each lobe.

Remarks. Stopes (1914) considered Dawson's Sphenopteris splendens (which she transferred to Oligocarpia) to be conspecific with Stur's Oligocarpia brongniartii. However, Abbott (1954), who re-examined the holotype of Sphenopteris splendens, concluded that the two species were not synonymous based on different lobing patterns and pinnule margins. Dawson's material did not include fertile remains, which put the synonymy further into doubt. I follow Bell (1938) and recommend that the name Sphenopteris splendens be restricted to its type material; its synonymy with Oligocarpia brongniartii is open to question. The present material is thus attributed to Oligocarpia brongniartii, which is based on much better, well-described material.

Although fragmentary and poorly preserved, the spec- imen figured as Oligocarpia brongniartii by Bell (1944, pl. XXV, figs. 2, 4) seems a good fit for this species. The same locality at Springhill (locality 1039) yielded a specimen figured by Bell (1944, pl. XLII, figs. 2, 4; Figs. 12a-b herein, after removal of occluding material with a vibratory tool) as Pecopteris (Senftenbergia?) sp. Although equally fragmentary as the specimen described by Bell as Oligocarpia brongniartii, this specimen is better preserved and clearly identifiable as Oligocarpia brongniartii. Bell compared Oligocarpia brongniartii with Senftenbergia pennaeformis, although this now seems irrelevant.

Comparisons. Pinnules of Oligocarpia mixta are smaller than those of Oligocarpia brongniartii, oblong, and with more deeply incised lobes. In addition, the sori of Oligocarpia mixta are smaller, comprising only three to five sporangia, in contrast to seven to twelve in Oligocarpia brongniartii. Vegetative pinnules of Oligocarpia gutbieri are larger and more equidimensional than those of Oligocarpia brongniartii. They are ovate to subtriangular, hardly if at all 
lobate (often only a sinuous margin); where present, lobes in Oligocarpia gutbieri are rounded and separated by shallow sinuses.

Stratigraphic and geographic distribution. Oligocarpia brongniartii is a common and widely represented species. Brousmiche (1983) recorded its range in Saar-Lorraine (Germany-France) as Westphalian C (Bolsovian) to Westphalian D (Asturian). Josten (1991) recorded Oligocarpia brongniartii from upper Westphalian B (Duckmantian) to upper Westphalian D (Asturian) in the Ruhr District of western Germany.

Occurrence in the Maritime Provinces, Canada. CumberLAND BASIN (Nova Scotia): Bell (1944): locality 1039 (GSC 9067 + GSC 9445 - labelled as Pecopteris (Senftenbergia?) sp; together with Renaultia schatzlarensis). SyDNEY BASIN (Nova Scotia): Bell (1938): locality 487 (GSC 1657); locality 490 (GSC 1649); locality 518 (GSC 1593). Bell (1966): locality 465 (GSC 1648).

Occurrence in the United States. OHIO: Abbott (1954).

\section{Family uncertain}

\section{Genus Sturia Němejc 1934}

1934 Štúria Němejc, p. 2-3.

1956 Sturia Němejc; Danzé, p. 79, 370.

1983 Sturia Němejc; Brousmiche, p. 273-274.

2017a Sturia Němejc; Frojdová et al., p. 154.

Type. Sturia amoena (Stur 1885) Němejc 1934.

Remarks. Němejc (1934) introduced Sturia to accommodate Hapalopteris amoena. He did not give a diagnosis but provided a detailed description of the fertile structure. Stur$i a$ 's fertile pinnules possess leptosporangiate sporangia, with small, free, sessile, oval sporangia that cluster in variable numbers. Sturia amoena is the only species of the genus yet described.

Sturia amoena (Stur 1885) Němejc 1934

(Figs. 13a-f)

* 1885 Hapalopteris amoena Stur, p. 52-54, Taf. XLI, figs. 7-7a.

* 1885 Hapalopteris bella Stur, p. 49-52, Taf. XLII, figs. 1-2 (acc. to Gothan 1941).

* 1913 Sphenopteris Schilleri Gothan, p. 147-148, Taf. 30, fig. 2 (acc. to Gothan 1941).

1923 Sphenopteris bella (Stur) Zeiller; Kidston, p. 127-129, pl. XXVII, figs. 1-3c.

* 1923 Sphenopteris quadriloba Kidston, p. 122-123, pl. XXV, figs. 1-2a (two specimens that came from the same horizon as Kidston's Sphenopteris amoenaeformis).

* 1923 Sphenopteris amoenoformis Kidston, p. 125127, pl. XXV, figs. 6-6a; pl. XXVI, figs. 1-3b (acc. to Danzé 1956).
$\$ 1934$ Štúria amoena Stur (gen. nov.) Němejc, p. 2-3, plate, figs. 1-3, figs. 4-6 (sporangia).

v 1944 Sphenopteris amoenaeformis? Kidston; Bell, p. 65, pl. XII, figs. 2, 4; pl. XIII, fig. 2.

v 1944 Sphenopteris (Renaultia?) schatzlarensis (Stur) Kidston; Bell, p. 67, pl. XV, fig. 1, fig. 3 (partly refigured herein as Figs. 13c-f).

v 1944 Sphenopteris (Zeilleria?) sp.; Bell, p. 74, pl. XXII, fig. 5; pl. XXIII, fig. 1.

1956 Sturia amoena (Stur) Němejc; Danzé, p. 370376, pl. LXXII, figs. 4-4a; pl. LXXIII, figs. 1-1d.

1963 Štúria amoena (Stur) Němejc; Němejc, Tab. LII, figs. 1-4, figs. 5-6 (sporangia) (same as Němejc 1934).

? 1966 Sphenopteris sp.; Gillespie et al., p. 104, pl. 32, fig. 3 (difficult to judge from the illustration at natural size).

? 1978 Sphenopteris schatzlarensis (Stur) Zeiller; Gillespie et al., p. 109, 115, 132, pl. 51, fig. 1 (same as Gillespie et al. 1966, pl. 32, fig. 3).

T 1983 Sturia amoena (Stur) Němejc; Brousmiche, p. 274-278 (including synonymy), pl. 73, figs. 1-1b (lectotype), figs. 2-2a (same as Stur 1885, Taf. XLII, fig. 1), figs. 3-3a (another part of lectotype), figs. 4-5a (same as Kidston 1923, pl. XXVI, figs. 2-3), figs. 6-6a (same as Kidston 1923, pl. XXV, fig. 6); pl. 74, figs. 1-1a (same as Gothan 1913, Taf. 30, fig. 2), figs. 2-3 (same as Stur 1885, Taf. XLII, fig. 1), figs. 4-8; text-figs. $78 \mathrm{~A}_{1}-79$.

? 1996 Sphenopteris cf. S. Schatzlarensis (Stur) Zeiller; Cross et al., p. 456, fig. 23-19.1 (figured at less than natural size).

v 2010 Sturia amoena (Stur) Němejc; Wagner and Álvarez-Vázquez, p. 266, 270.

T 2017a Sturia amoena (Stur) Němejc; Frojdová et al., p. 154-158, pl. 1, figs. 1-5 (lectotype), figs. 6-10; pl. 2, figs. 1-8 (sporangia and spores); text-figs. 1A-B (drawings).

Description. Frond at least tripinnate. Antepenultimate rachis sturdy, straight, flat, smooth, ca. $2 \mathrm{~mm}$ wide. Pinnae of penultimate order apparently subtriangular (always incomplete), alternate, spaced out or partly overlapping. Penultimate rachis inserted at $45-50^{\circ}$, slightly flexuous, rounded, smooth, ca. 0.5-0.6 mm wide. Last order pinnae decurrent, alternate, spaced out or touching laterally depending on the position in the frond; subtriangular, with margins gradually tapering to a blunt apical segment. Dimensions: 11-20 $\mathrm{mm}$ long and 6 $-10 \mathrm{~mm}$ broad; length/breadth ratio = 1.8-2. Last order rachis inserted at $75-90^{\circ}$, thin, slightly flexuous, rounded, smooth, ca. $0.2 \mathrm{~mm}$ wide. Pinnules alternate, oblique to the rachis, well-spaced, thus giving an airy aspect to the pinna. Less developed pinnules obliquely inserted and united to the rachis by only part of the basal width; decurrent, small, subtriangular. Fully developed (and characteristic) pinnules trilobate to quintulobate, 


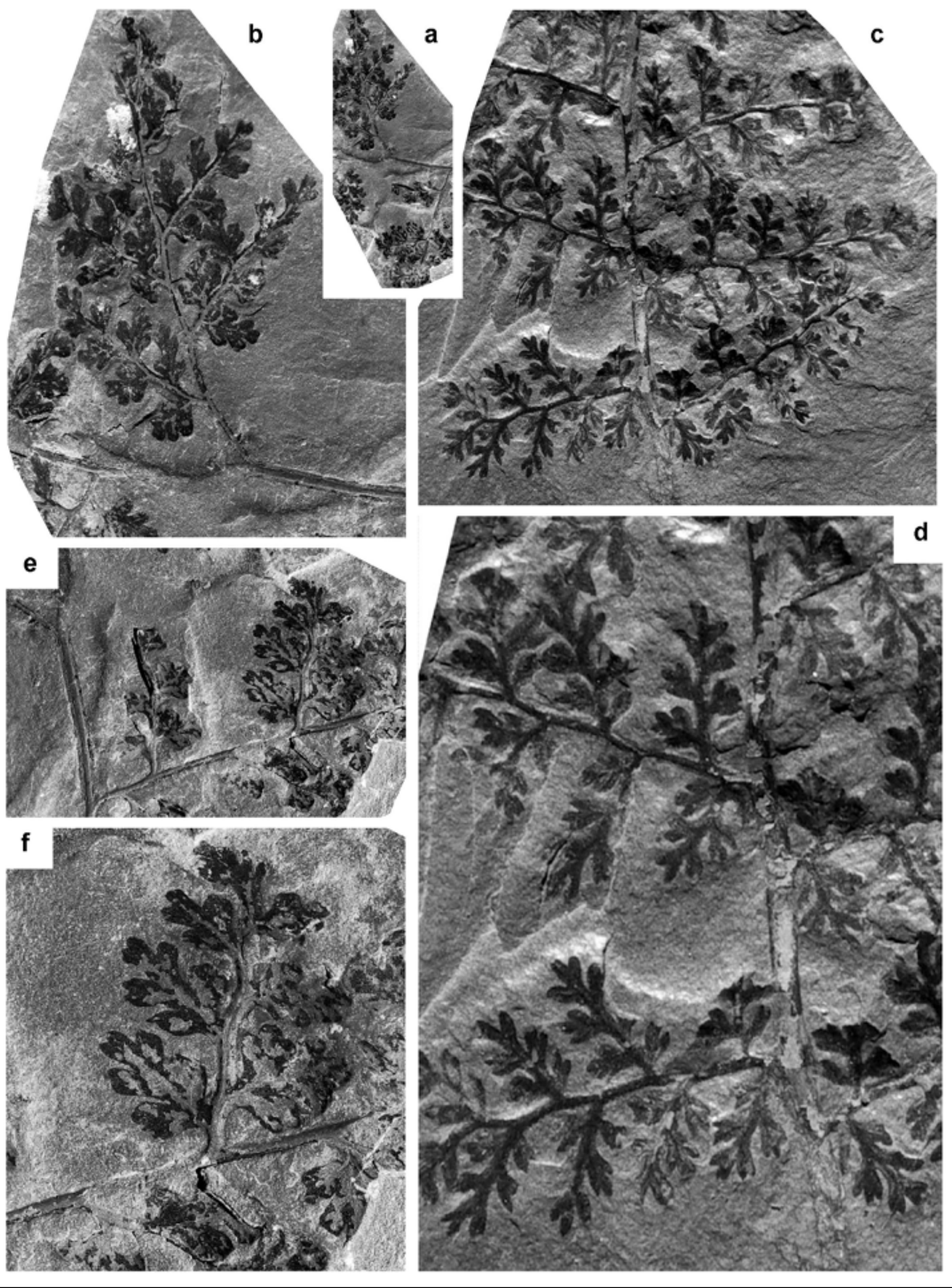


almost equidimensional, with slightly divergent, broad and bluntly pointed lobes, separated by shallow sinuses. They pass gradually into pinnae at the development of a fourth pair of lobes. Dimensions: $1.5-3 \mathrm{~mm}$ long and $1.5-2.5 \mathrm{~mm}$ broad; length/breadth ratio $=1-1.2$. Lamina fairly thin to moderately convex. Nervation consists of a thin, decurrent and slightly flexuous midrib that gives off a single vein to each lobe.

Remarks. I include in Sturia amoena the two relatively large and fairly well-preserved specimens from Joggins that Bell (1944, pl. XV, figs. 1, 3) figured as "Sphenopteris (Renaultia?) schatzlarensis". Unfortunately, these specimens have been varnished, obscuring morphological details and making photography difficult. Bell's illustrations (at natural size) are thus difficult to interpret. Reillustration herein (Figs. 13c-d) of the upper right hand corner of Bell's pl. XV, fig. 3 nonetheless provides evidence of a strong resemblance between Bell's material and the holotype of Sturia amoena.

Also three poorly figured specimens included in Sphenopteris amoenaeformis? by Bell (1944, pl. XII, figs. 2, 4; pl. XIII, fig. 2 - all from the same locality) are here regarded as belonging to Sturia amoena. Bell's material undoubtedly resembles Kidston's (1923) illustrated specimens of Sphenopteris amoenaeformis, a species that was placed in synonymy with Sturia amoena by Danzé (1956), who did not mention Bell's record.

Two moderately well-preserved pinna fragments of the antepenultimate order that Bell (1944, pl. XXII, fig. 5; pl. XXIII, fig. 1) identified as Sphenopteris (Zeilleria?) sp. also seem to accord well with Sturia amoena. Both specimens were re-examined for the present study. Although Bell (1944) compared these specimens with Sturia amoena, he did not include them in that species because he considered the size of penultimate pinnae to be different. The specimen figured by Bell (1944, pl. XXIII, fig. 1) shows a transition from spread-out thin-limbed pinnules to stiffer pinnules with a reduced lamina. The latter are suggestive of fertile pinnules, but no sporangia occur to confirm this possibility. Bell (1944, p. 74) mentioned the presence of poorly preserved sporangia borne distally at the end of lobes, which he thought were split into a four-segmented cupula-like bodies suggestive of Zeilleria. However, my re-examination of the specimen provided no evidence of sporangia. Perhaps, the rough texture of the silty mudstone on which this specimen is imprinted led to Bell's interpretation.
Comparisons. The angle of insertion of pinna and pinnules of Sturia amoena, the small size of pinnules, their subtriangular shape, and the bluntly pointed lobes all suggest a resemblance to Renaultia hemingwayi. However, the latter species shows a basal anadromous pinnule that is relatively longer, thus producing an asymmetry in last order pinnae. This is not present in Sturia amoena. Vegetative pinnules of Renaultia schatzlarensis also possess broad, obtusely pointed lobes, but these are more spread out and more deeply incised. Fully developed pinnules of Sturia amoena are smaller and more equidimensional. The equally small pinnules of Sphenopteris bronnii are longer and composed of up to four pairs of filiform lobes, with acute apices, in contrast to the almost equidimensional, broad and bluntly pointed lobes separated by shallow sinuses in Sturia amoena.

Stratigraphic and geographic distribution. Sturia amoena seems to have been misidentified by several authors and so the existing records of its stratigraphic occurrence are suspect. However, it appears that Sturia amoena is relatively widespread and common throughout the Westphalian. The lectotype is from Duckmantian-Bolsovian strata in Belgium. Brousmiche (1983) stated that this species ranges through the Westphalian, and possibly above. She observed its frequent occurrence in lower Westphalian C (Bolsovian) and upper Westphalian D (Asturian) coal-bearing strata of Saar-Lorraine. Frojdová et al. (2017a) figured Duckmantian specimens from the Czech Republic. Gothan's Sphenopteris schilleri was described from the upper part of the Muldengruppe (i.e. upper Duckmantian) in Upper Silesia, Poland. The type material of Kidston's Sphenopteris amoenaeformis came from two localities in the Clackmannanshire and Lanarkshire coalfields, Midland Valley of Scotland, from strata of late Langsettian age. The holotype of Sphenopteris quadriloba originated from the same level in the Lanarkshire coalfield. In the Iberian Peninsula, Wagner and Álvarez-Vázquez (2010) recorded Sturia amoena from lower Bolsovian strata of the Peñarroya-Belmez-Espiel coalfield, southwestern Spain, and from the lower Asturian of the Central Asturian Coalfield, northwestern Spain.

Occurrence in the Maritime Provinces, Canada. CumberLAND BAsin (Nova Scotia): Bell (1944): locality 736 (two pieces without catalogue number - together with Dorycordaites palmaeformis and Samaropsis sp.); locality 1125 (GSC 9351 + GSC 9622 - figured as Sphenopteris (Zeilleria?) sp. by Bell); locality 1367 (one piece without catalogue

Figure 13. (previous page) (a) Sturia amoena $(\times 1)$. Specimen without catalogue number. Origin: South Joggins section, from unspecified beds (locality 1388). (b) Enlargement $(\times 3)$ of the near-terminal part of a pinna of the penultimate order in specimen figured in Fig. 13a. Specimen shows characteristic, fully developed, trilobate to quintulobate pinnules, with broad, bluntly pointed, slightly divergent lobes. (c) Sturia amoena $(\times 3)$. GSC 4449. Detail of the right hand side of the specimen figured as Sphenopteris (Renaultia?) schatzlarensis by Bell (1944, pl. XV, fig. 3). Origin: same as for Figs. 13a-b (locality 1388). (d) Enlargement $(\times 6)$ of part of the same specimen. (e) Sturia amoena $(\times 3)$. Enlargement of lower part of specimen in Fig. 13a. Origin: same as for Figs. 13a-d (locality 1388). (f) Another enlargement $(\times 6)$ of the same specimen. Repository: Geological Survey of Canada, Ottawa. 
number - poorly preserved); locality 1380 (GSC 10975 + six pieces without catalogue number); locality 1388 (GSC 4449 + GSC 9929 - both figured as Sphenopteris (Renaultia?) schatzlarensis by Bell; together with small fragments of Adiantites adiantoides + GSC $11009+$ one piece without catalogue number); locality 1390 (GSC 5576 + GSC 5580 + GSC 9372 - all figured as Sphenopteris amoenaeformis? by Bell + six fragmentary specimens without catalogue number); locality 1416 (two pieces without catalogue number - together with Sphenophyllum cuneifolium); locality 1564 (four pieces; poorly preserved and without catalogue number together with Sphenophyllum cuneifolium); locality 2986 (one piece without catalogue number). NEw BRUNSWICK: Bell (1944): locality 655 (two small pieces without catalogue number).

Occurrence in the United States. West VIRgINIA: Gillespie et al. (1966); Gillespie et al. (1978).

Order Botryopteridales Meyen 1987

Family Tedeleaceae Eggert and Taylor 1966

Genus Senftenbergia Corda 1845

1845 Senftenbergia Corda, p. 91.

1938-39 Senftenbergia Corda; Radforth, p. 751-760.

Type. Senftenbergia pennaeformis (Brongniart 1822) Stur 1877.

Remarks. Vegetative pinnules of Senftenbergia are pecopteroid, united to the rachis by their entire basal width. Fertile pinnules are generally reduced in lamina, and the sporangia normally occupy the entire width between midrib and pinnule margin; they possess annulate, relatively large, free sporangia of pyriform to ovoid shape, placed in lateral position on secondary veins.

\section{Senftenbergia plumosa (Artis 1825) Stur 1877} (Fig. 14)

* $1825 \quad$ Filicites plumosus Artis, p. 17, pl. XVII.

* 1832 Sphenopteris caudata Lindley and Hutton, p. 137, pl. 48 (acc. to Kidston 1886).

* 1834 Sphenopteris crenata Lindley and Hutton, p. 57-58, pls 100-101 (acc. to Kidston 1893).

* 1834 Pecopteris serra Lindley and Hutton,

p. 71-72, pl. 107 (acc. to Kidston 1886).

* 1836 Pecopteris dentata Brongniart, p. 346-348, pl.

123, figs. 1-5; pl. 124 (acc. to Kidston 1886).

* 1836 Pecopteris delicatula Brongniart, p. 349-350, pl. 116, figs. 6-6A (acc. to Kidston 1886).

* 1836 Aspidites Silesiacus Göppert, p. 364-367, Taf. XXVII; Taf. XXXIX, fig. 1 (acc. to Kidston 1886).

* 1836 Aspidites Glockeri Göppert, p. 375-376, Taf. XXIX, figs. 1-4 (acc. to Kidston 1886).

* 1838 Pecopteris mucronata Presl in Sternberg, p. 159 (referring to Sternberg 1821, Taf. XVI, fig. 6 - photograph in Kvaček and Straková 1997, pl. 37, fig. 1) (acc. to Němejc 1940).

* 1854 Pecopteris angustifida Ettingshausen, p. 45, Taf. 16, fig. 1 (acc. to Kidston 1886).

1854 Pecopteris Glockeriana Presl in Sternberg; Ettingshausen, p. 44, Taf. 17, fig. 1.

* 1862 Neuropteris serrulata Dawson, p. 320, pl. XV, figs. 35a-b (diagrammatic drawings - acc. to Stopes 1914).

1868 Pecopteris (Alethopteris) serrulata Dawson, $\mathrm{p}$. 534, 548, 553, Fig. 192K (Dawson compared with Pecopteris plumosa, Pecopteris serra, Pecopteris dentata and Pecopteris delicatula).

* 1868 Pecopteris (Alethopteris) preciosa Hartt in Dawson, p. 534, 548, 553-554, Fig. 192L (although Stopes 1914 refigured these specimens as indeterminable, she compared with Pecopteris plumosa).

1871 Pecopteris (Aspidites?) serrulata Dawson, p. 55, 92, pl. XVIII, figs. 207-209 (Dawson compared with Pecopteris silesiaca, a synonym of Senftenbergia plumosa).

1871 Pecopteris (Aspidites?) preciosa Dawson, p. 56, 92, pl. XVIII, fig. 210 (specimen figured photographically by Stopes 1914, pl. XXIII, fig. 61 , who regarded it as indeterminable), figs. 211-211a (photographed by Stopes 1914, pl. XXIV, fig. 63).

1871 Neuropteris serrulata Dawson, p. 49-50, 92, pl. XVIII, fig. 213 (drawing).

$\$ 1877$ Senftenbergia plumosa (Artis) Stur, p. 187 [293].

1879-80 Pecopteris dentata Brongniart; Lesquereux, p. 240-241, pl. XLIV, figs. 4-4a.

1879-80 Pecopteris pennaeformis Brongniart; Lesquereux, p. 239-240, Pl. XLV, figs. 1-2a.

1896 Dactylotheca plumosa (Artis) Kidston; Kidston, p. 205-219 (including synonymy), pl. I, figs. 1-4b; pl. II, figs. 5-9c, fig. 14 (sporangia); pl. III, figs. 10-13c.

p 1899 Pecopteris (Dactylotheca) dentata (Brongniart) Zeiller; White, p. 75-78 (including synonymy), pl. XXIV, figs. 1-2; pl. XXV; pl. XXVI, figs. 2-4; pl. XXVII; non pl. XXVI, fig. 1 (resembles Pecopteris micromiltonii).

1914 Pecopteris plumosa (Artis) Brongniart; Stopes, p. 44-46, pl. XII, figs. 27-29 (types of Pecopteris serrulata); text-fig. 7 (drawing).

1925 Pecopteris pennaeformis Brongniart; Noé, p. 15, pl. XXXII.

1925 Pecopteris dentata Brongniart; Noé, p. 15, pl. XXXIII.

1937 Dactylotheca plumosa (Artis) Kidston; Jongmans, p. 406, 407, pl. 26, fig. 70.

k 1937-38 Dactylotheca plumosa (Artis) Kidston; Radforth, p. 387-395, pl. I, fig. 1, fig. 2 (sporangium), figs. 3-5, figs. 6-12 (sporangia); pl. II, 


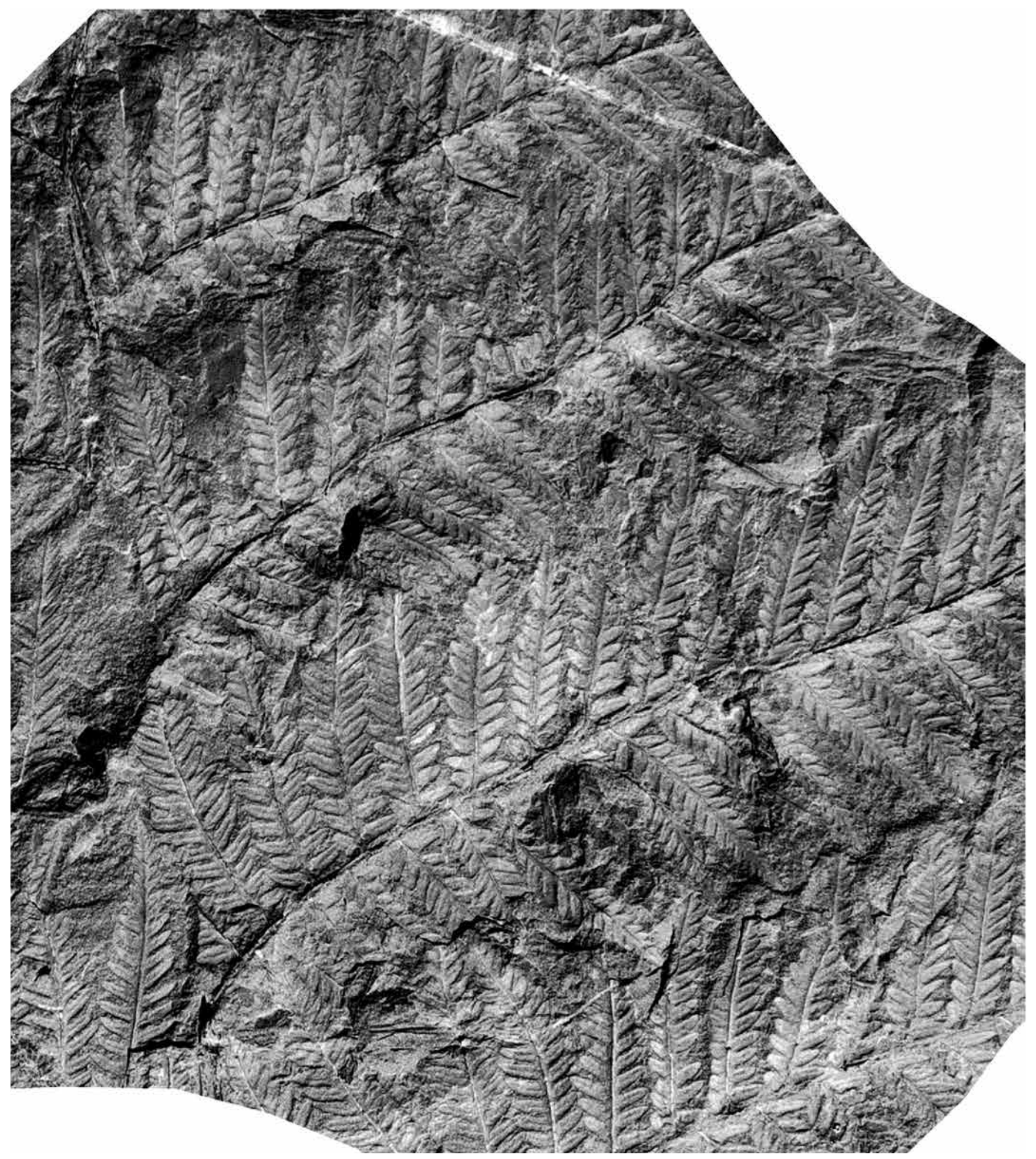

Figure 14. Senftenbergia plumosa $(\times 2)$. FGM 999GF 13.11/21.2. Antepenultimate order pinna showing the characteristic subtriangular pinnules. Note the slightly longer first basal acroscopic pinnule in last order pinna, and the first basiscopic shorter and more deltoid one. Origin: Spicer's Cove, Nova Scotia. Repository: Fundy Geological Museum, Parrsboro, Nova Scotia. 
figs. 1-12 (spores).

1938 Dactylotheca plumosa forma dentata Bell, p. 76-77, pl. LXXIII, fig. 3; pl. LXXVII, figs. 3-4; pl. LXXX, figs. 1, 3 .

k 1943 Pecopteris plumosa var. dentata Sterzel; Andrews, p. 432-434, pl. 11, figs. 10-12 (cuticles), figs. 13-14.

Pecopteris (Senftenbergia) plumosa forma crenata Bell, p. 84-85, pl. XXXVIII, figs. 1-4; pl. XXXIX, figs. 5-6.

? 1949 Pecopteris plumosa (Artis) Brongniart; Arnold, p. 187, 261, pl. XXVI, fig. 5 (too poorly figured for a proper identification).

1951 Pecopteris (Senftenbergia) plumosa-dentata Dalinval; Corsin, p. 199-208 (including synonymy), pls CXII-CXIV; pl. CXV (as forma crenata); pl. CXVI; pls CXVII, CXVIII (as forma crenata); text-figs. 42a-c (drawing).

1957 Dactylotheca plumosa (Artis) Kidston; Janssen, p. 134, 136, Fig. 117q (drawing), Fig. 120.

1957 Senftenbergia pennaeformis (Brongniart) Stur; Janssen, p. 138, 139, Fig. 117p (drawing), Fig. 121.

1958 Dactylotheca plumosa (Artis) Kidston; Langford, p. 170, Fig. 290; Figs. 291a-c (drawings).

1959 Pecopteris (Dactylotheca) plumosa (Artis) Kidston; Canright, p. 31, pl. 3, fig. 15.

1959 Asterotheca arborescens (Schlotheim ex Brongniart) Stur; Canright, p. 31, pl. 3, fig. 11.

1959 Pecopteris (Senftenbergia) pennaeformis (Brongniart) Stur; Canright, p. 32, pl. 3, fig. 12.

1960 Pecopteris (Senftenbergia) plumosa-dentata Dalinval, p. 51, pls V-XV.

1962 Pecopteris (Senftenbergia) pennaeformis (Brongniart) Stur; Bell, p. 35, pl. XXVI, fig. 2. Senftenbergia plumosa (Artis) Stur; Bell, $\mathrm{p}$. 12, pl. V, fig. 18.

1968 Pecopteris dentata Brongniart; Basson, $\mathrm{p}$. $88-89$, pl. 17, fig. 2 (poorly figured); pl. 18 , fig. 1.

1969 Pecopteris plumosa (Artis) Brongniart; Darrah, p. 127-128, 214, pl. 13, fig. 4 (recorded as Pecopteris dentata-plumosa in the plate caption).

1982 Pecopteris plumosa forma dentata Sterzel; Oleksyshyn, p. 86-88, Figs. 17E-F.

2001 Senftenbergia plumosa (Artis) Stur; Bek and Pšenička, p. 218-227, pl. I, figs. 1-3, 6 (spores), figs. 4-5; pl. II, figs. 1-8 (spores); pl. III, figs. 1-3 (sporangia), fig. 4; pl. IV, figs. 1-2 (sporangia), fig. 3; pl. V, figs. 1-2 (sporangia), figs. 3-5 (spores). et al., p. 286, pl. VII, fig. 2.

k 2003 Senftenbergia plumosa (Artis) Stur; Pšenička and Bek, p. 301, pl. I, figs. 1-3; pl. II, figs. 1-5 (spores); pl. III, figs. 1-5 (cuticle); pl. IV, figs. 1-4 (cuticle); text-figs. 3-6.

2005 Senftenbergia plumosa (Artis) Stur; Bashforth, p. 48-51, pl. 11, figs. 1-5; pl. 12, figs. 6 , 8 ; text-fig. 24E.

2006 Senftenbergia plumosa (Artis) Stur; Calder et al., p. 184, Fig. 12A.

2006 Pecopteris plumosa (Artis) Brongniart; Wittry, p. 22, Figs. 1, 2; Fig. 3 (drawing after Dalinval 1960).

T 2009 Senftenbergia plumosa (Artis) Stur; Cleal et al., Fig. 4 (copy of Artis's original plate).

2016 Senftenbergia plumosa (Artis) Stur; DiMichele et al., p. 64, 67, Figs. 15a-15c.

2016 Senftenbergia plumosa (Artis) Stur; Opluštil et al., p. 169, 170, 171, 172, Figs. 14D, 15C.

Excludenda:

1958 Pecopteris (Dactylotheca) plumosa (Artis) Kidston; Cross, p. 193, pl. 7, fig. 2 (difficult to judge from the figuration at natural size, but resembling Dicksonites plukenetii).

2017 cf. Senftenbergia plumosa (Artis) Stur; DiMichele et al., p. 54, fig. 30.3 (fragmentary and difficult to judge, but pinnules with different shape).

Description. Frond at least tripinnate. Antepenultimate rachis straight, flat, punctate, up to $6 \mathrm{~mm}$ wide. Pinna of penultimate order apparently lanceolate (incomplete), touching or slightly overlapping, at least $90 \mathrm{~mm}$ long. Penultimate rachis inserted at $60-80^{\circ}$, straight or slightly flexuous, rounded, smooth or finely striate longitudinally, ca. $1.5-2 \mathrm{~mm}$ wide. Last order pinnae alternate, closely spaced or slightly overlapping; linear-lanceolate, with distal pinnules gradually fusing into a blunt terminal; apical angle $35-45^{\circ}$. Dimensions: $15-40 \mathrm{~mm}$ long and $2-5 \mathrm{~mm}$ broad; length/breadth ratio $=7.5-8$. Last order rachis inserted at $45-90^{\circ}$, straight, rounded, smooth or longitudinally striate, up to $0.7 \mathrm{~mm}$ wide. Pinnules alternate, obliquely inserted, united to the rachis by the entire basal width or even confluent, constituting a narrow wing along the rachis; pinnules subtriangular, with entire or slightly crenate margins and apices that vary from acute to broadly rounded; first basal catadromous pinnule slightly larger than the lateral ones; first anadromous pinnule smaller, with a more or less distinctly marked basal lobe. Dimensions: $4-9 \mathrm{~mm}$ long and 1-1.5 $\mathrm{mm}$ broad; length $/$ breadth ratio $=4-6$. Lamina thin, flat or slightly convex. Nervation well-marked. Midrib prominent, decurrent, slightly flexuous and extending into the apex; lateral veins straight, departing from midrib at a narrow angle; simple (in the smaller pinnules) or once forked (larger pinnules). Fertile pinnules similar in shape to the vegetative ones. Sporangia small, ovoid, placed upon lateral veins and occupying most of the space between midrib and pinnule margin. 
Remarks. This variable but easily identifiable species was recorded by Bell (1944) as one of the most common and widespread plant fossils in the Cumberland Basin of Nova Scotia. Bell (1944) recorded the Canadian specimens as Pecopteris (Senftenbergia) plumosa forma crenata, highlighting the crenulate margin of pinnules, and contrasting it with Pecopteris (Senftenbergia) plumosa forma dentata, which has entire margins and more rounded apices; the latter would apparently characterize the upper Westphalian. However, he noted that both forms may be found in one and the same frond and that the distinction is one of degree, and thus of limited taxonomic use. Most authors regard the different forms of Senftenbergia plumosa as representing different parts of large fronds (e.g., Göppert 1836, Taf. XXVII; Stur 1885, Taf. XLV, fig. 1; Dalinval 1960, pl. VIII, fig. 1).

Comparisons. Senftenbergia pennaeformis has perpendicularly inserted, free pinnules of subrectangular shape, parallel margins, broadly rounded apex, and more sturdy aspect. Its venation is characterized by a thick and straight midrib giving off lateral veins that are once or twice forked at a wide angle and reach the pinnule margin nearly perpendicularly; these are embeded in a convex lamina. The shorter pinnules of Senftenbergia plumosa may be distinguished from those of Senftenbergia aspera by the thicker, convex lamina, more rounded apices, and more deeply imprinted veins in the latter.

Stratigraphic and geographic distribution. Senftenbergia plumosa is a very common, geographically widespread species; it is long-ranging, from upper Namurian (Yeadonian) through the entire Westphalian. The holotype originated from lower Duckmantian strata in the Yorkshire coalfield. It is most common in lower and middle Westphalian strata. Its stratigraphic usefulness is limited.

Occurrence in the Maritime Provinces, Canada. CumberLAND BASIN (Nova Scotia): Bell (1944): locality 858 (GSC 6536); locality 1031 (GSC 9444 + GSC 9445 - fragmentary); locality 1050 (GSC 9210); locality 1053 (GSC 9947); locality 1086 (GSC 10055 - fragmentary); locality 1087 (GSC 10123 - fragmentary and poorly preserved; together with Dorycordaites palmaeformis + one piece without catalogue number - together with Neuropteris obliqua, Alethopteris sp., Dorycordaites palmaeformis, Calamites sp., and Asterophyllites cf. longifolius); locality 1386 (GSC 9213); GSC 9209; locality 1481 (one piece without catalogue number - fragmentary; together with rootlets); locality 1517 (one piece without catalogue number - fragmentary); locality 2253 (one piece without catalogue number - fragmentary and poorly preserved); locality 3110 (GSC $3076-$ together with Cordaites sp. and Samaropsis sp. + GSC 9200). Bell (1966): locality 1362 (GSC 15006). Calder et al. (2006). Fundy Geological Museum: FGM 999 GF 13.11/21.2 (together with Dorycordaites palmaeformis). SAINT JoHN (NEW BRUnswick): locality 352 (128b - labelled as Pecopteris serrulata); locality 788 (one piece without catalogue num- ber); locality 2567 (two pieces, part and counterpart, without catalogue number - both poorly preserved).

Occurrence in the United States. IllinoIs: Noé (1925), Andrews (1943), Janssen (1957), Langford (1958), Darrah (1969), Wittry (2006). Indiana: Canright (1959). МicHIGAN: Arnold (1949). Missouri: Lesquereux (1879-80), White (1899), Basson (1968). Pennsylvania: Lesquereux (1879-80), Oleksyshyn (1982). Rhode Island: Lesquereux (1879-80). West Virginia: Jongmans (1937), Blake et al. (2002).

\section{Order Coenopteridales Zimmermann 1930 Family Corynepteridaceae Cleal 1993}

\section{Genus Alloiopteris Potonié 1897}

1893 Heteropteris Potonié, p. 44 (homonym - name introduced previously for extant plants).

1897 Alloiopteris Potonié, p. 138.

1956 Alloiopteris Potonié; Danzé, p. 94-96.

1983 Alloiopteris Potonié; Brousmiche, p. 84.

Type. Alloiopteris quercifolia (Göppert 1836) Potonié 1899.

Remarks. Alloiopteris refers to parallel-bordered last order pinnae with an approximately equal width throughout, and generally possessing narrowly confluent pinnules that are small and of virtually the same size and shape along the entire pinna length.

The name Alloiopteris is used for vegetative pinnules and pinnae that are similar in shape to fertile remains assignable to Corynepteris, or for specimens in which evidence for fertile status is uncertain; the distinction between Alloiopteris and Corynepteris is thus practical rather than definitive. Alloiopteris is widely distributed and relatively common, though, its occurrence is probably determined by environmental parameters. It ranges throughout the Pennsylvanian.

\section{Alloiopteris almaensis Bell 1944}

(Figs. 15a-b)

1935 Alloiopteris (Corynepteris) coralloides forma compacta Gothan, p. 41, Taf. 41, fig. 2 (lower part).

${ }^{*} \mathrm{v} 1944$ Alloiopteris almaensis n. sp. Bell, p. 75, pl. XXIV, fig. 2; pl. LXXI, fig. 2.

? 1944 Alloiopteris (Corynepteris) coralloides (Gutbier) Zeiller; Bell, p. 75, pl. XXII, fig. 4 (poorly preserved).

1956 Corynepteris coralloides var. compacta Gothan; Danzé, p. 312-313, pl. XLVII, figs. 4-6a.

Description and remarks. Bell (1944, p. 75) described a single pinna fragment of the penultimate order (holotype), as a new species, Alloiopteris almaensis. This species has been generally ignored by later authors.

Alloiopteris almaensis is characterized by pecopteroid pinnules joined at the base by a narrow strip of lamina associated with a slightly decurrent midrib; this imparts a slightly asymmetrical aspect to the pinnules. Basal catadromous 

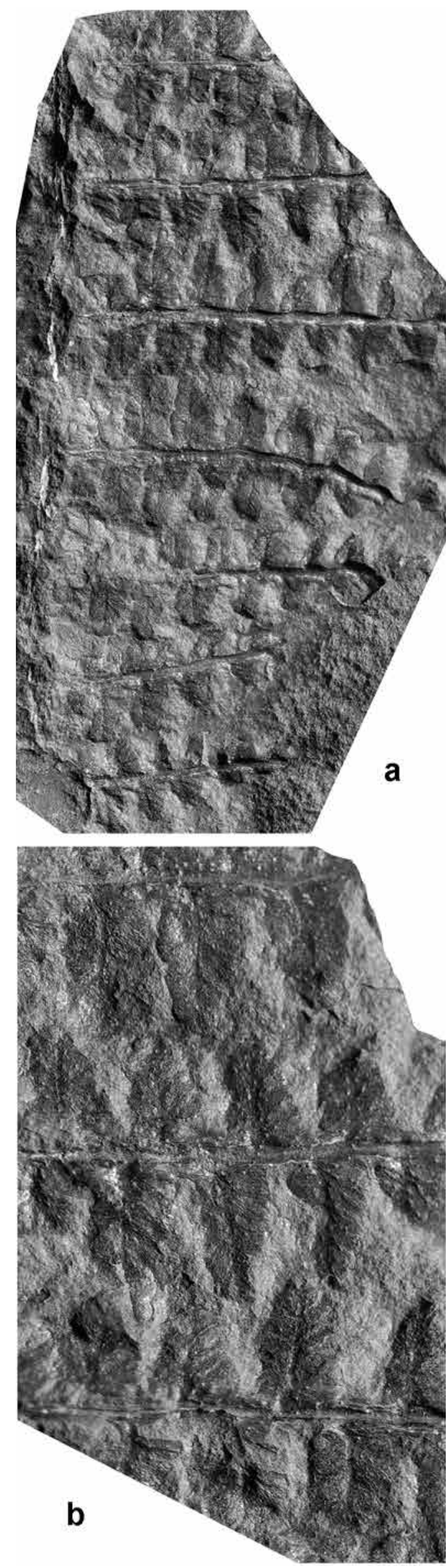

Figure 15. (a) Alloiopteris almaensis ( $\times 3$ ). DRC-991-64. Origin: Joggins section (Donald Reid collection), Nova Scotia. (b) Enlargement $(\times 6)$ of the same specimen. Repository: Joggins Fossil Centre, Joggins, Nova Scotia.

pinnules are much more strongly developed (larger) than lateral ones, and thus stand out as individual elements. Lateral pinnules are variable in size along the pinna length, up to $5 \mathrm{~mm}$ long and $3 \mathrm{~mm}$ wide; they are weakly lobate, with angular lobes that appear bluntly pointed. Overall pinnule shape is subrectangular, with a rounded to bluntly pointed apex. The midrib is thin, decurrrent, flexuous and extending into the pinnule apex. Lateral veins are equally thin, once forked and widely spaced, with vein endings that seem to correspond to small projections on the pinnule margin.

Apart from the holotype, I include in Alloiopteris almaensis five additional fragmentary specimens from the type locality that have not been previously illustrated, as well as a specimen figured by Bell (1944, pl. XXII, fig. 4) as Alloiopteris (Corynepteris) coralloides, from the same area of New Brunswick. A more complete specimen from the Donald Reid Collection at Joggins, Nova Scotia, is also included and figured herein (Figs. 15a-b).

Bell (1944) compared Alloiopteris almaensis with Alloiopteris junghannii, a taxon introduced by Gothan (1913, p. 115-116, Taf. 25, figs. 4-5; Taf. 26, fig. 3) from the Upper Silesian Coal Basin. Two additional specimens of Alloiopteris junghannii from Langsettian strata of the same basin were figured by Stopa (1957, Tab. XX, figs. 1-2), and a further specimen was figured by Josten (1983, Taf. 38, figs. 2, 2a-b; Abb. 73) from the upper Namurian B (Marsdenian) of the Ruhr District, western Germany. Josten's specimen shows relatively smaller (shorter) pinnules which are all of near-equal size. Gothan's illustration at natural size does not show details of venation, but Beltz (1989, Taf. V, fig. 5; Taf. VI, figs. 1-1b) provided enlargements of the holotype. These show two kinds of pinnule. One type is similar to Alloiopteris sternbergii, displaying perpendicularly inserted, decurrent pinnules, united to the rachis by the entire base and narrowly confluent, of subquadrangular shape, with four short, pointed teeth on the distal margin; its venation consists of a single, decurrent vein that gives off a single lateral vein to each tooth. The other type of pinnule is subrectangular, more elongate, and has three to five pointed lobes with bifid, pointed teeth on the margin, the last feature apparently distinguishing it from Alloiopteris almaensis. However, larger specimens are required to establish the full range of morphological variation and whether one or two species are represented. Both Alloiopteris junghannii and Alloiopteris almaensis are known only from small fragments that are insufficient to show the intraspecific variation. In the absence of fertile remains, neither can be attributed to Corynepteris.

Beltz (1989) regarded Alloiopteris almaensis as synonymous with Alloiopteris pecopteroides, which was described by Gothan (1913, p. 110) from Upper Silesia. However, the fragmentary specimen figured by Gothan (1913, Taf. 25, 
figs. 2-2a; text-fig. 8) shows pinnules with a higher length/ breadth ratio as well as being of near-equal size throughout the pinna. The neotype designated by Beltz (1989, Taf. VI, figs. 2-2a), also shows more closely packed pinnules and a basal catadromous pinnule that is of similar size and shape to the lateral ones.

Alloiopteris almaensis most closely resembles a specimen figured as Alloiopteris coralloides forma compacta by Gothan (1935, Taf. 41, fig. 2 - lower part) from Langsettian strata in the Ruhr District of Germany. Two other remains figured as Corynepteris coralloides var. compacta by Danzé (1956, pl. XLVII, figs. 4-6) from the Langsettian of Nord/Pas-deCalais, northwestern France, also appear to represent the same taxon. All of these specimens show subrectangular, pecopteroid, weakly lobate pinnules with bluntly pointed apices. The nervation is also similar, with a thin, slightly decurrent, flexuous midrib extending into the tip of the pinnule. I include these European specimens in the synonmy with Alloiopteris almaensis.

Stratigraphic and geographic distribution. Alloiopteris almaensis is too rare and indistinctive to be useful stratigraphically. Bell's (1944) specimens from New Brunswick, and those from the Donald Reid Collection from the Joggins section are from Langsettian strata and are the only known material from Canada. The European specimens recorded as Corynepteris coralloides forma compacta are also from the Langsettian.

Occurrence in the Maritime Provinces, Canada. Cumberland Basin (Nova Scotia): Donald Reid collection, Joggins, Nova Scotia (1999): DRC-997 64. SAINT John (New Brunswick): Bell (1944): locality 1457 (GSC 9893 figured as Alloiopteris (Corynepteris) coralloides); locality 1461 (GSC 8569 - holotype); locality 1461b (five pieces without catalogue number - fragmentary).

Genus Corynepteris Baily 1860

emend. Galtier and Scott 1979

1860 Corynepteris Baily, p. 237-241.

1883 Saccopteris Stur, p. 64 [696] (based on Andrae's Sphenopteris essinghii).

1883 Grand'Eurya Zeiller, p. 203 (based on Gutbier's Sphenopteris coralloides).

1979 Corynepteris Baily; Galtier and Scott, p. 115.

1983 Corynepteris Baily; Brousmiche, p. 56-57.

Type. Corynepteris stellata Baily 1860.

Remarks. Corynepteris is characterized by perpendicularly inserted, parallel-sided last order pinnae of almost equal width throughout. Pinnules are small, attached to the rachis by the entire basal width, and generally confluent. Sporangia are large, ovate, sessile, and mostly with five sporangia in a sorus.
Corynepteris angustissima (Sternberg 1823) Němejc 1938 (Figs. 16a-c)

* 1823 Pecopteris angustissima Sternberg, p. 29, Taf. XXIII, figs. 1a-1b.

* 1854 Asplenites Sternbergii Ettingshausen, p. 42, 73, Taf. 20, figs. 2-3; Taf. 20, fig. 4 (as Asplenites lindsaeoides in the plate explanation) (acc. to Němejc 1938).

* 1884 Pecopteris Georgiana Lesquereux, p. 759-760, pl. XCVIII, figs. 6-6a (Lesquereux' species has been rarely cited).

1900 Aloiopteris (sic) georgiana (Lesquereux) White, p. 776, 792, 793, 866, 883.

1923 Corynepteris (Zygopteris) Sternbergi, Kidston, p. 301-305, pl. LXXIV, figs. 1-3, 5, 5a-5d (spores); pl. LXXVIII, figs. 1-2.

1937 Alloiopteris Sternbergii, Jongmans, p. 405, pl. 25, fig. 66.

1938 Corynepteris angustissima, Němejc, p. 15, 41, pl. I, figs. 3-4; pl. III, figs. 8-10; text-figs. 4-5, 9b.

v 1944 Alloiopteris (Corynepteris) sternbergi (Ettingshausen) Bertrand; Bell, p. 74, pl. XXIII, fig. 2 (herein Fig. 16a), fig. 3; pl. XXIV, fig. 1 (herein Figs. 16b-c).

v 1944 Corynepteris sp.; Bell, p. 75-76, pl. XXV, figs. 1, 3. 1957 Corynepteris sternbergi (Ettingshausen) Zeiller; Janssen, p. 116, 117, Figs. 97, 99e (drawing).

1958 Corynepteris sternbergi (Ettingshausen) Zeiller; Langford, p. 256, Fig. 465.

1963 Alloiopteris sternbergii (Ettingshausen) Potonié; Cridland et al., p. 69, pl. 21, fig. 44 (magnificent specimen).

v 1966 Alloiopteris (Corynepteris) sternbergi (Ettingshausen) Zeiller; Bell, p. 14, 16, 50, pl. VI, fig. 4; pl. VII, fig. 1; pl. XXIV, figs. 3-4.

? 1967 Corynepteris angustissima (Sternberg) Němejc; Tidwell, p. 36, pl. 5, figs. 2-3 (difficult to judge from the illustrations).

? 1969 Alloiopteris winslowii White; Darrah, p. 149, 215, pl. 22, fig. 1 (poorly figured).

1975 Alloiopteris sternbergi (Ettingshausen) Potonié; Jennings, p. 52-55, pl. 1, figs. 1-2 (adpression), figs. 3-9 (anatomy); text-fig. 1 (drawing).

1979 Alloiopteris angustissima (Sternberg) Potonié; Álvarez Ramis et al., p. 127-128, Taf. 1, figs. 1, 2; Abb. 1.

1979 Corynepteris sternbergii (Ettingshausen) Zeiller; Galtier and Scott, p. 89-97, pl. 1, fig. 6 (same as Kidston 1923, pl. LXXIV, fig. 5), fig. 7 (sporangia), fig. 8; pl. 2, figs. 1-7; pl. 3, figs. 1-11 (sporangia and spores); pl. 4, figs. 6, 8, fig. 7 (sporangia); text-figs. 2-5 (drawings).

1983 Corynepteris angustissima (Sternberg) Němejc; Brousmiche, p. 57-63 (including synonymy), pl. I, figs. 1-3 (same as Ettingshausen 1854, Taf. 20, figs. 2-4), figs. 4-5a, figs. 6-6a (same as Álvarez 


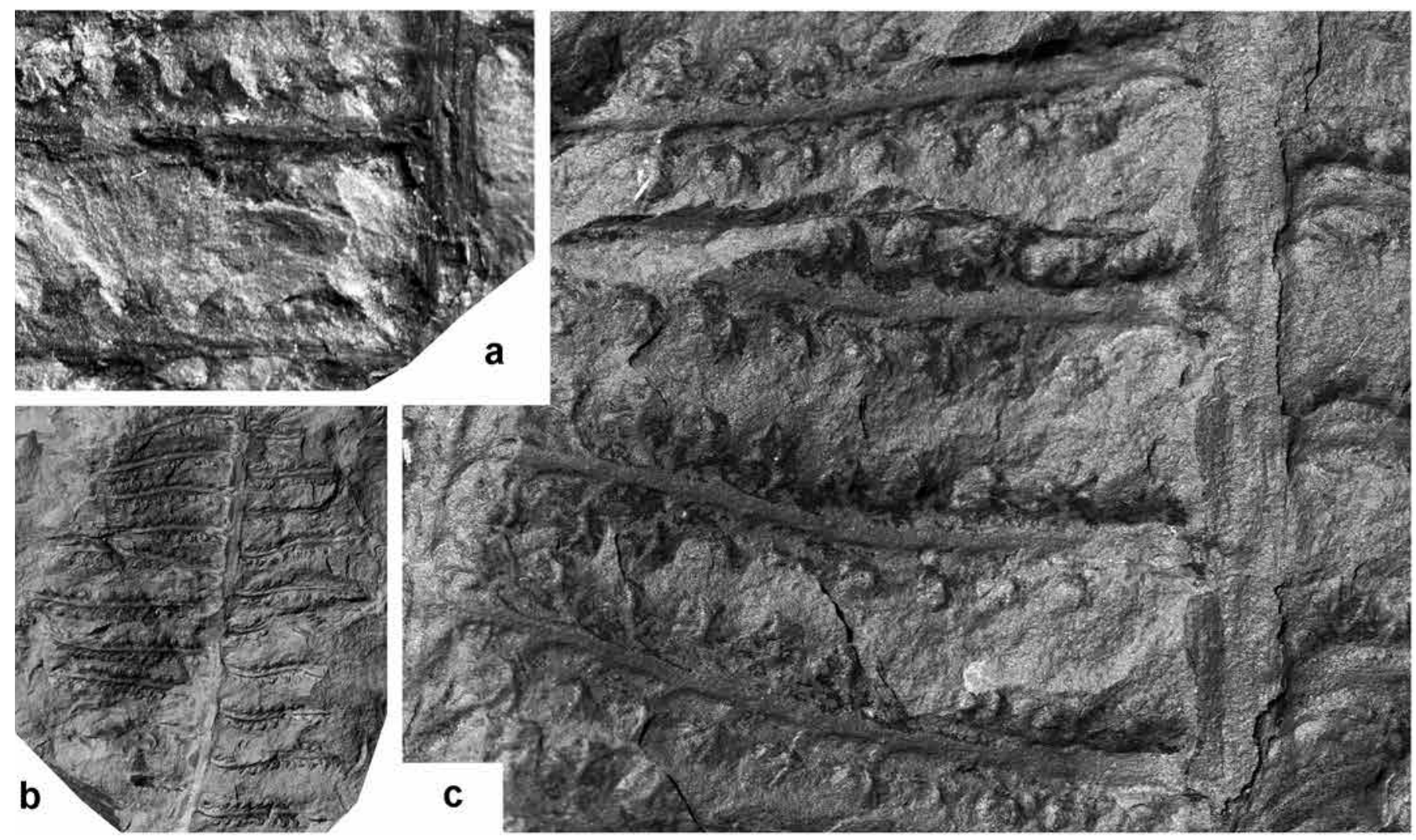

Figure 16. (a) Corynepteris angustissima $(\times 6)$. GSC 9364. Detail of the specimen figured as Alloiopteris (Corynepteris) sternbergi by Bell (1944, pl. XXIII, fig. 2). Origin: Springhill, $\mathrm{n}^{\circ} 2$ mine, waste dump (locality 1039), Nova Scotia. (b) Corynepteris angustissima $(\times 1)$. GSC 9426. Figured as Alloiopteris (Corynepteris) sternbergi by Bell (1944, pl. XXIV, fig. 1). Origin: Smith Brook, about 2 miles from junction with South Branch Black River, Springhill area (locality 1052), Nova Scotia. (c) Enlargement $(\times 6)$ of part of specimen in Fig. 16b. Note the asymmetric aspect of pinnules and the short, pointed teeth on the upper margin. Repository: Geological Survey of Canada, Ottawa.

Ramis et al. 1979, Taf. 1, fig. 1), figs. 7-8a; pl. 2, figs. 1-2a, figs. 3-3a (same as Stur 1885, Taf. LII, fig. 3), figs. 4-6, figs. 7-7a (same as Gothan 1935, Taf. 43, fig. 2), figs. 8-8a (same as Stur 1885, Taf. LII, fig. 5); pl. 3; text-figs. 9A-C; textfig. 10.

1984 Alloiopteris sternbergi (Ettingshausen) Potonié; Jennings, p. 307, pl. 3, fig. 5 (same as Jennings 1975, pl. 1, figs. 1-2).

1985 Alloiopteris Georgiana (Lesquereux) White; Gillespie and Crawford, p. 255, pl. III, fig. 8.

? 1996 Alloiopteris sternbergii (Ettingshausen) Potonié; Cross et al., p. 448, figs. 23-15.7, 23-15.8 (difficult to judge from the illustrations).

T 1997 Corynepteris angustissima (Sternberg) Němejc; Kvaček and Straková, p. 34, pl. 5, fig. 2 (photograph of holotype).

2002 Alloiopteris angustissima (Sternberg) Potonié; Blake et al., pl. XXXIV, fig. 4.

2011 Corynepteris sternbergii (Ettingshausen) Zeiller; Pšenička \& Opluštil, p. 73-75, pl. VII, figs. 1-6.

2016 Corynepteris sternbergii (Ettingshausen) Zeiller; Opluštil et al., p. 171, Fig. 14B.
Description. Frond at least bipinnate. Penultimate rachis straight, rounded, punctate and with longitudinal striae, ca. 1.5-2 mm wide. Last order pinnae alternate, well spaced, parallel-sided and narrow, with rigid aspect. Dimensions: up to $35 \mathrm{~mm}$ long (incomplete) and $3 \mathrm{~mm}$ wide. Last order rachis inserted at right angle, straight, rounded, punctate and longitudinally striate, ca. $0.5 \mathrm{~mm}$ wide. Pinnules inserted perpendicularly, alternate, closely spaced, decurrent and united to the rachis by their entire basal width with a narrow confluence; subquadrate, markedly asymmetric, with four short, pointed teeth on the distal margin. Dimensions: $1-1.3 \mathrm{~mm}$ long and $0.9-1.1 \mathrm{~mm}$ wide; length $/$ breadth ratio $=$ 1.1-1.2. Lamina thick, convex. Nervation composed by a single, decurrent vein that gives off, at a wide angle, one lateral vein to each tooth.

Remarks. Bell (1944, pl. XXIII, figs. 2-3; pl. XXIV, fig. 1) figured as Alloiopteris (Corynepteris) sternbergi three fragmentary, but distinctive, specimens from Springhill, Nova Scotia. Bell (1966, pl. VI, fig. 4; pl. VII, fig. 1) figured another specimen from the Springhill area and one from the Sydney Basin (Bell 1966, pl. XXIV, figs. 3-4). Brousmiche (1983, p. 57) accepted Bell's identification in her revision of the 
genus Corynepteris; Galtier and Scott (1979) did not mention Bell's record.

I also include in Corynepteris angustissima the fragmentary specimen figured as Corynepteris sp. by Bell (1944, pl. $\mathrm{XXV}$, figs. 1, 3). Although its preservation is poor, it seems characteristic of this species.

Comparisons. Alloiopteris erosa differs from Corynepteris angustissima in the general shape of its pinnules, which are subrectangular, obliquely inserted and strongly decurrent, with both lateral margins parallel to the rachis, as well as by the indentations of the upper margin. Its venation also differs in having a markedly decurrent midrib and forked lateral veins.

Stratigraphic and geographic distribution. Although never abundant, Corynepteris angustissima is a widely distributed, long-ranging species. It occurs from Chokierian (Namurian) to the uppermost Stephanian. The holotype is from uppermost Duckmantian strata of the Radnice Member, Kladno Basin, Bohemia, Czech Republic.

Occurrence in the Maritime Provinces, Canada. CumberLAND BAsin (Nova Scotia): Bell (1944): locality 881 (GSC 5970 - together with Calamites suckowii + GSC 5971 both specimens figured as Corynepteris sp.); locality 1039 (GSC 9040 + GSC 9364 - figured as Alloiopteris (Corynepteris) sternbergi + four pieces without catalogue number; together with Alethopteris urophylla, Zeilleria avoldensis, Renaultia schatzlarensis and Calamites sp.); locality 1052 (GSC 9426 - figured as Alloiopteris (Corynepteris) sternbergi; together with rootlets + one specimen in the counterpart of GSC 8619 - together with Renaultia footneri and Cordaites sp.); locality 1075 (GSC 9624 - together with Stigmaria ficoides); locality 1982 (one fragmentary specimen without catalogue number) + GSC 9891 (figured as Alloiopteris (Corynepteris) sternbergi). Bell (1966): locality 1052 (GSC 15053 - figured as Alloiopteris (Corynepteris) sternbergi; together with rootlets). Donald ReID COLlection, Joggins, Nova Scotia (1999): DRC 99150 (together with Cordaites principalis). Sydney BASIn (Nova Scotia): Bell (1966): locality 1338 (GSC 15044 - figured as Alloiopteris (Corynepteris) sternbergi).

Occurrence in the United States. Georgia: Lesquereux (1884), Gillespie and Crawford (1985). IllinoIs: Janssen (1957), Langford (1958), Darrah (1969), Jennings (1975), Jennings (1984). Kansas: Cridland et al. (1963). PenNSYlvania: White (1900). West Virginia: Jongmans (1937), Blake et al. (2002).

\section{Order uncertain}

Genus Discopteris Stur 1883

1883 Discopteris Stur, p. 61-64 [693-696].

1956 Discopteris Stur; Danzé, p. 58-60, 264-267.

1978 Discopteris Stur; Pfefferkorn, p. 170-172.

1983 Discopteris Stur; Brousmiche, p. 279-280.
Type. Discopteris karwinensis Stur 1883.

Remarks. Fertile pinnules characterized by annulate sporangia; sori rounded to oval, placed at the end of lateral veins or in the middle of lobes. Vegetative pinnules sphenopteroid, more or less lobate, joined to the rachis by the entire basal width or part of it. First basal catadromous element in ultimate, penultimate and antepenultimate order pinnae is a deeply segmented aphlebia.

\section{cf. Discopteris vuellersii Stur 1885}

(Fig. 17)

1883 Discopteris Vüllersi Stur, p. 63, $64[695,696]$

(name only).

* 1885 Discopteris Vüllersi Stur, p. 156, Taf. XXXIII, fig. 3.

T 1978 Discopteris vuellersi Stur; Pfefferkorn, $\mathrm{p}$. 183-188, Taf. 15, fig. 10 (Stur's holotype), figs. 11-13 (details of holotype); Abb. 8-9.

T 1983 Discopteris vuellersii Stur; Brousmiche, $\mathrm{p}$. 284-287, pl. 77, figs. 1-1e (details of holotype), figs. 2-2a.

v 1995 Discopteris vuellersii Stur; Álvarez-Vázquez, p. 196-198, lám. 66, figs. 1-3a.

Remarks. I tentatively include in Discopteris vuellersii a fragmentary but otherwise well-preserved specimen from Springhill, Nova Scotia that has not been previously illustrated. Discopteris vuellersii is a Westphalian species that is easily recognizable by its asymmetrical pinnules with bifid, deeply incised, acute lobes.

Stratigraphic and geographic distribution. Although rarely cited, Discopteris vuellersii is known from Langsettian to lower Asturian strata. The holotype is from Duckmantian strata of the Intra-Sudetic Basin of Lower Silesia.

Occurrence in the Maritime Provinces, Canada. CumBERLAND BASIN (Nova Scotia): Bell (1944): locality 1031 (GSC9441 - together with fragmentary remains of Alethopteris sp., Zeilleria sp. and Calamites sp.).

Genus Sphenopteris Brongniart 1822 sensu lato 1822 Sphenopteris Brongniart, p. 233.

Remarks. Sphenopteris is a problematic genus. Although the type, Sphenopteris elegans, is a Mississippian seed plant, the name is used also in a broader sense for ferns for which the reproductive structures are unknown and the systematic position is uncertain. This is the case for the species of Sphenopteris described below.

$$
\begin{array}{ll} 
& \begin{array}{l}
\text { Sphenopteris cuneoliformis Bell } 1944 \\
\text { (Figs. 18a-b) }
\end{array} \\
* \quad 1944 & \begin{array}{l}
\text { Sphenopteris cuneoliformis n. sp. Bell, p. 64, pl. } \\
\text { VII, figs. 2-3 (herein Figs. 18 a-b). }
\end{array}
\end{array}
$$

Description. Bipinnate fragment preserved as an adpression 


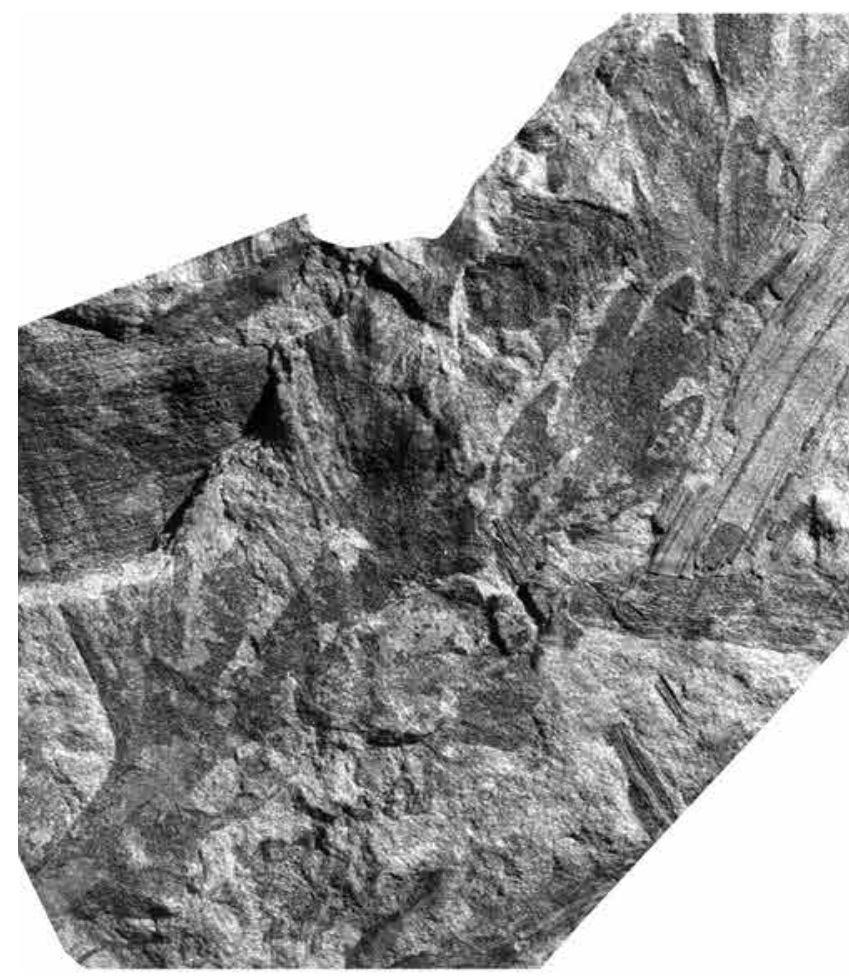

Figure 17. cf. Discopteris vuellersii $(\times 3)$. GSC9441. Origin: Reid Brook, Mapleton, about $0.8 \mathrm{~km}$ above junction with Maccan River (locality 1031), Nova Scotia. Repository: Geological Survey of Canada, Ottawa.

on silty mudrock that is too coarse-grained for the outline of pinnules to be fully preserved. Last order pinnae lanceolate, closely spaced or only slightly touching laterally. Last order pinnae are exceedingly small, up to $8 \mathrm{~mm}$ long and $3.5 \mathrm{~mm}$ wide, with up to four pairs of lateral pinnules and a simple, distinct apical segment. Last order rachis inserted at ca. $45^{\circ}$, straight, rounded, thin, ca. $0.2 \mathrm{~mm}$ wide. Pinnules inserted by a short footstalk, ca. 1.1-1.5 mm long, almost isodiametric, entire and subcuneate, with a rounded apex in the smaller pinnules, and split into basal and terminal cuneate lobes in the larger ones. Lamina relatively thick, vaulted. No venation visible.

Remarks. Bell (1944, pl. VII, figs. 2-3) introduced Sphenopteris cuneoliformis on the basis of a single, fragmentary specimen. Although adequately described, the illustration is poor, possibly leading later authors to overlook it. Bell (1944) did not provide any comparisons, probably regarding it as clearly distinct from other sphenopterids. Although a species based on fragmentary remains will always be of questionable value, Sphenopteris cuneoliformis is retained here provisionally.

Comparisons. Most closely resembling Sphenopteris cuneoliformis is a specimen with small, lanceolate last order pinnae and small, subcircular, stalked pinnules illustrated by Danzé (1956, pl. LXXXVI, figs. 1-1a) as Sphenopteris cf. parviloba.
This specimen is from an unspecified locality in Nord, northwestern France. The "true" Sphenopteris parviloba was introduced in the same paper (Danzé 1956, p. 513-516, pl. LXXXIII, figs. 3-5a) and is from upper Bolsovian strata. It has small pinnules with a generally orbicular outline, united to the rachis along most of their basal width and divided into up to three short, rounded lobes separated by shallow sinuses. Sphenopteris parviloba and Sphenopteris cf. parvilo$b a$ are clearly two different species.

Sphenopteris cuneoliformis also resembles Sphenopteris microcyclos, another species characterized by small, rounded, more or less isodiametric pinnules. Poorly illustrated by its author (Gothan 1941, Taf. 52, fig. 3), Sphenopteris microcyclos was redefined by Danzé (1956, pl. LXXVI, figs. 1-2), who illustrated better-preserved specimens that differ from Sphenopteris cuneoliformis only by having a denticulate border (as shown in Danze's text-fig. 50) (note that denticulations are not always evident in poorly preserved specimens). Gothan's specimen is from the Duckmantian of the Upper Silesian Basin, whereas the specimens illustrated by Danzé are from middle to upper Bolsovian strata of Nord/Pas-deCalais, France.

Sphenopteris cuneoliformis is also quite similar to specimens from Belgium figured as Hapalopteris microscopica by Stur (1885, Taf. XLIII, figs. 1-3). The latter species is characterized by small last order pinnae with very small pinnules, but the larger ones are trilobate.

Sphenopteris effusa possess similar pinnules, entire or three-lobed, isodiametric, oval to obovate in shape, with a rounded apex. However, these are stalked (as are those of Sphenopteris cf. parviloba), and pinnae and pinnules are of larger size. The holotype of Sphenopteris effusa (Lindley and Hutton 1937, pl. 204; Kidston 1923, pl. XVI, figs. 2-2a) is from lower Westphalian B (lower Duckmantian) strata of Felling Colliery, Durham, northern England. It shows a strongly developed rachis of the antepenultimate order that suggests a lower position in the frond than Sphenopteris cuneoliformis.

Stratigraphic and geographic distribution. Until now, Bell's specimen is the only record of Sphenopteris cuneoliformis. It is from the Oxford area, Cumberland Basin, Nova Scotia.

Occurrence in the Maritime Provinces, Canada. CumberLAND BASIN (Nova Scotia): Bell (1944): locality 862 (GSC 5674).

Sphenopteris harttii Dawson 1862

(Fig. 19)

* 1862 Sphenopteris Harttii Dawson, p. 321, pl. XVI, figs. 48a-b (drawings).

T 1868 Sphenopteris Harttii Dawson, p. 551, Fig. 192E (same as Dawson 1862, pl. XVI, fig. 48b).

1888 Sphenopteris Harttii Dawson, p. 73, Fig. 232E.

T 1871 Sphenopteris Harttii Dawson, p. 52, pl. XVI, fig. 176 (same as Dawson 1862, pl. XVI, fig. 48b, and Dawson 1868, Fig. 192E), figs. 177-177a. 

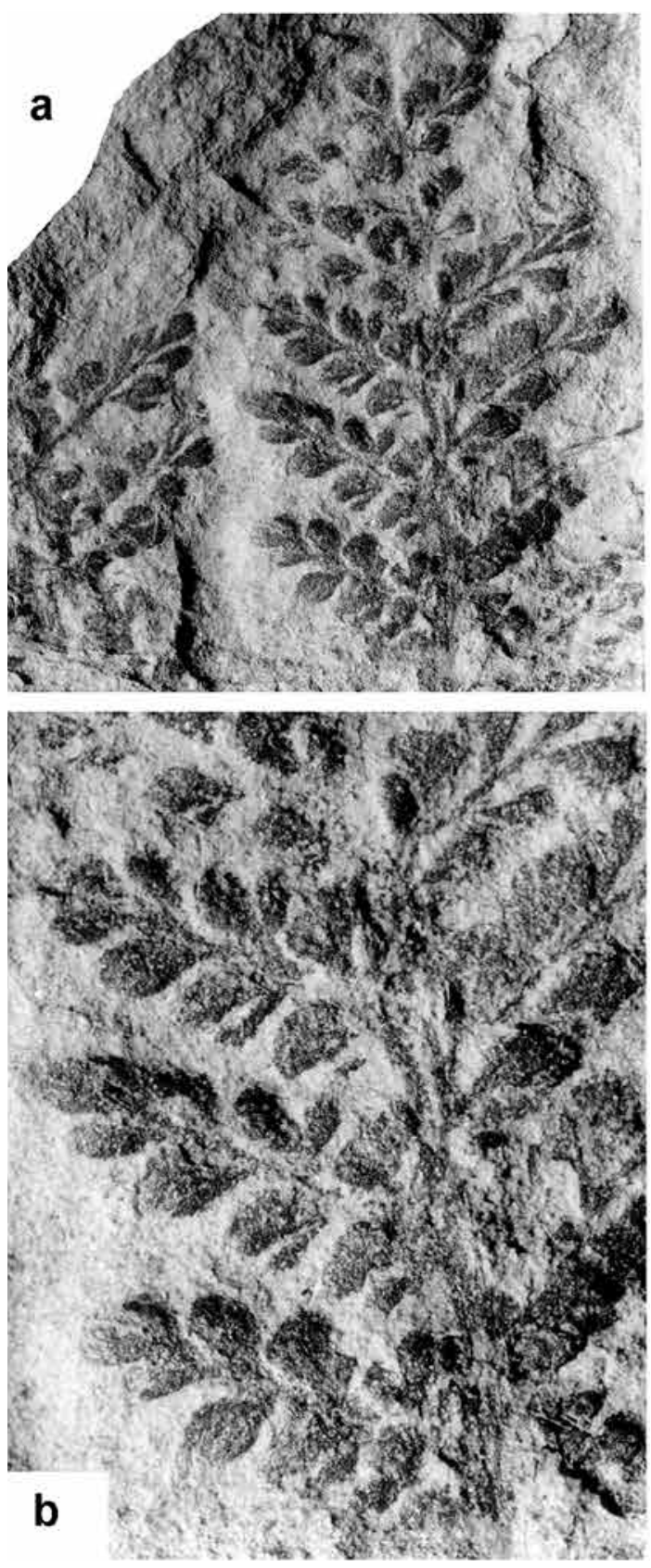

Figure 18. (a) Sphenopteris cuneoliformis $(\times 3)$. GSC 5674. Holotype (and only specimen available). Note the almost isodiametric, entire, subcuneate pinnules, with relatively thick, vaulted lamina. Figured by Bell (1944, pl. VII, figs. 2, 3). Origin: Oxford area, Brook east of River Philip (locality $862)$, Nova Scotia. (b) Enlargement $(\times 6)$ of the same specimen. Repository: Geological Survey of Canada, Ottawa.

p 1871 Hymenophyllites curtilobus Dawson; Dawson, p. 53, pl. XVI, fig. 178; non pl. XVI, figs. 179179a (indeterminable, fragmentary specimen with filiform lobes that Stopes 1914 indicated was lost).

1910 Sphenopteris Harttii Dawson; Matthews, p. 248 (name only).
Description and remarks. Here I describe previously unfigured, fragmentary remains of pinnae of penultimate order labelled as Sphenopteris harttii, a name introduced by Dawson (1862) for material from Saint John. Dawson's original figures and description are poor, and no additional material of Sphenopteris harttii has been recorded subsequently. Only Schimper (1869, p. 409) and Kidston (1886, p. 227) briefly mentioned Sphenopteris harttii.

The specimens studied here (two pieces, part and counterpart) are up to $29 \mathrm{~mm}$ long and $25 \mathrm{~mm}$ wide, show pecopteroid, decurrent pinnules joined at the base by a strip of lamina; overall, they are subrectangular, with small, angular lobes; the first basal catadromous pinnule is smaller. Dimensions: 7-9 $\mathrm{mm}$ long and 2-3 mm wide. Midrib is decurrent, thin, although distinct in the thin lamina; it extends into the pinnule apex. Lateral veins are thin, widely spaced, departing from the midrib at a wide angle, with one lateral vein to each lobe.

Stopes $(1914$, p. 37, 105, 110) regarded Sphenopteris harttii as synonymous with Diplotmema subfurcatum (a pteridosperm, now included in Palmatopteris), whereas Bell (1944, p. 72) considered Sphenopteris harttii as synonymous with Zeilleria hymenophylloides. In my view, neither synonymy is correct.

As in the case of Sphenopteris cuneoliformis, and despite the problems associated with a species based on fragmentary remains, Sphenopteris harttii is retained here; as far as I know there is no other species comparable with this taxon.

Stratigraphic and geographic distribution. The material newly described here and Dawson's $(1862,1868,1871)$ material are from Saint John, New Brunswick; the material is thus within the range of upper Langsettian to middle Bolsovian age, but a more precise age has yet to be determined.

Occurrence in the Maritime Provinces, Canada. SAInt John (New Brunswick): Dawson (1862, 1868, 1871). Geological Survey of Canada (material figured and described here): locality 117.

Sphenopteris cf. laciniosa Álvarez-Ramis et al. 1978 (Figs. 20a-b)

* 1978 Sphenopteris laciniosa Álvarez-Ramis et al., p.20, Taf. 9, fig. 6.

T 1983 Sphenopteris laciniosa Álvarez-Ramis et al.; Brousmiche, p. 325-329, pl. 88, figs. 1-1a (holotype), figs. 2-7a; text-fig. 98.

Description. Frond at least tripinnate. Pinnae of penultimate order alternate, touching laterally or slightly overlapping. Dimensions: at least $40 \mathrm{~mm}$ long (incomplete) and 30 $\mathrm{mm}$ broad. Penultimate rachis inserted at $80-90^{\circ}$, straight, rounded, smooth, $0.5 \mathrm{~mm}$ wide. Last order pinnae alternate, closely spaced; subtriangular, with maximum width corresponding to the second pair of basal pinnules. Dimensions: 10-15 $\mathrm{mm}$ long and 5-6 $\mathrm{mm}$ wide; length/breadth ratio = $2-2.5$. Last order rachis inserted at $70-80^{\circ}$, slightly flexuous, 


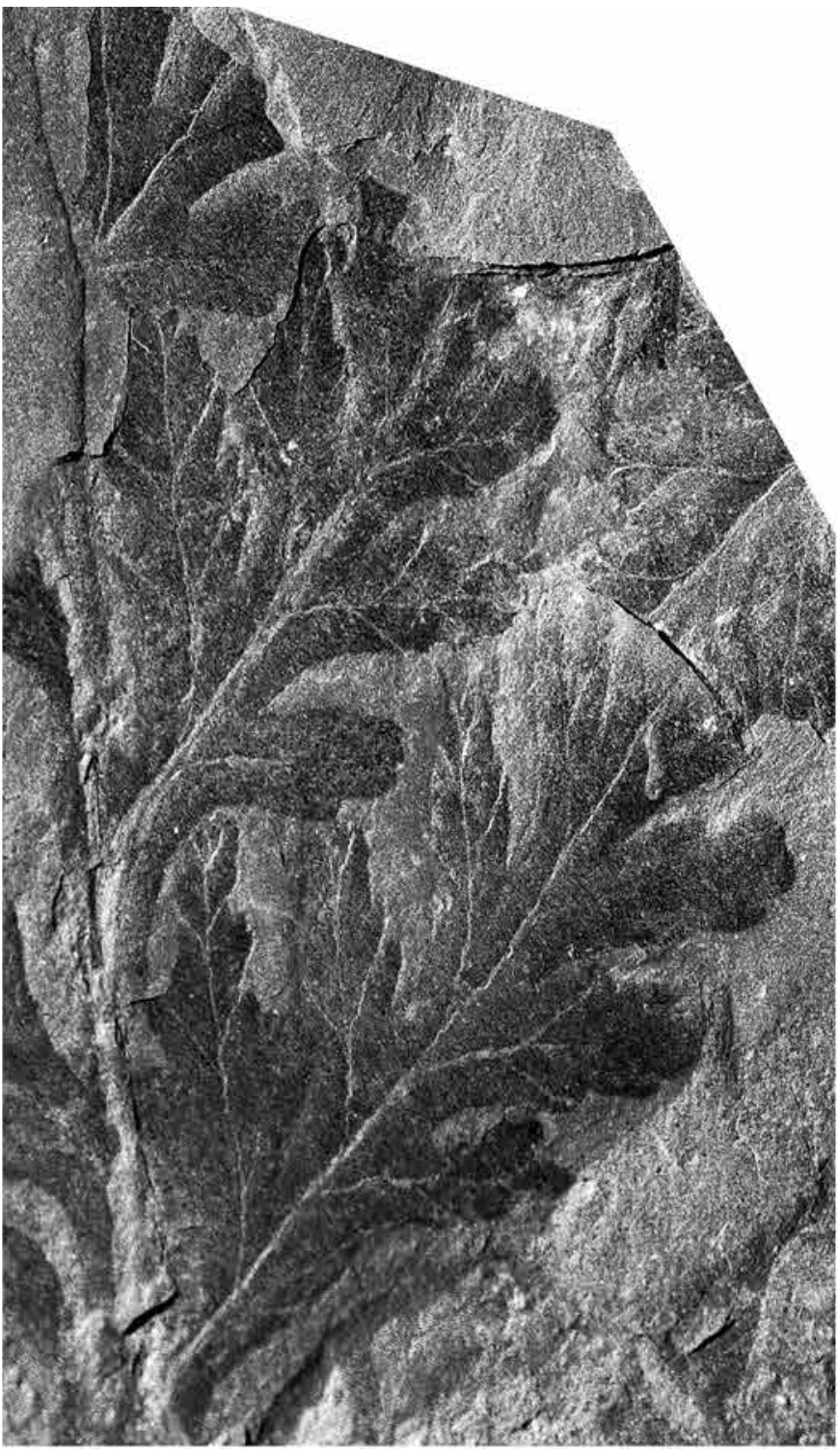

Figure 19. Sphenopteris harttii $(\times 6)$. Specimen without catalogue number. Note the decurrent, confluent and pecopteroid pinnules, with angular lobes, and the wellmarked, decurrent midrib. Origin: Fern Ledges, Saint John (locality 117), New Brunswick. Repository: Geological Survey of Canada, Ottawa.

rounded, smooth, ca. $0.3 \mathrm{~mm}$ wide, narrowly winged due to confluent pinnule bases. Pinnules alternate, obliquely inserted, decurrent. Fully developed pinnules subquadrangular to subrectangular, obliquely inserted, with a slightly constricted base and composed of up to three pairs of bluntly pointed lateral lobes. Basal catadromous pinnule much shorter than the standard laterals (about half the length) and consisting of only three to four lobes. Dimensions: $3-5 \mathrm{~mm}$ long and $2.5-3 \mathrm{~mm}$ wide; length $/$ breadth ratio $=1.2-1.6$. Lamina thin, delicate. Venation well-marked, consisting of a ca. $0.1 \mathrm{~mm}$ width, slightly decurrent, nearly straight midrib that extends into the pinnule apex and gives off a lateral vein to each lobe.
Remarks. The unillustrated Canadian specimen studied here, stored at the Fundy Geological Museum, conforms to Sphenopteris laciniosa in the shape and dimensions of pinnules, their decurrent base, equidimensional growth, and the presence of bluntly pointed lobes. Although Brousmiche (1983) described a lesser development of the first basal catadromous pinnule of last order pinnae, these pinnules are still markedly shorter in the Canadian material, at half length, so the specimen cannot be assigned confidently and is designated as Sphenopteris cf. laciniosa.

Comparisons. In comparison with the Canadian material, Renaultia chaerophylloides has more sturdy pinnules with indented margins and more acute lobes. Fully developed pinnules of Renaultia schatzlarensis are of similar size to those of Sphenopteris cf. laciniosa and also show decurrent bases; but they are composed of five broader, more spreading, deeply incised, simple or bifid, obtusely pointed lobes.

Stratigraphic and geographic distribution. Sphenopteris laciniosa is rarely cited and never abundant. The holotype is from upper Bolsovian strata of Saarland, Germany. Brousmiche (1983) indicated that the species is characteristic of the Bolsovian.

Occurrence in the Maritime Provinces, Canada. Cumberland Basin (Nova Scotia): Fundy Geological MuseUM: FGM 999 GF 13.1/21.2 (together with Dorycordaites palmaeformis and rootlets).

\section{Sphenopteris sp. A}

(Figs. 21a-c)

Description. Frond at least bipinnate. Penultimate rachis straight, flat, smooth, ca. $2.25 \mathrm{~mm}$ wide. Last order pinnae alternate, closely spaced; subtriangular, gradually tapering in the apical part to an elongate, subrounded, poorly individualized terminal. Dimensions: $35-120 \mathrm{~mm}$ long and $10-30 \mathrm{~mm}$ broad; length/breadth ratio $=3.5-4$. Last order rachis inserted at right angle, rounded, smooth, ca. $0.5 \mathrm{~mm}$ wide. Pinnules alternate, subrectangular, elongate, obliquely inserted and broadly attached to the rachis (pecopteroid aspect); the larger ones show slightly lobed margins, rounded apex and a lobatopteroid venation. Dimensions: 5-12 mm long and $2-3 \mathrm{~mm}$ broad; length/breadth ratio $=2.5-4$. Lamina thin, flat. Nervation composed by a slightly decurrent, very thin midrib, and lateral veins once or twice forked.

Remarks. The above description is based on a previously unfigured, unlabelled specimen from New Brunswick, illustrated herein as Figs. $21 \mathrm{a}-\mathrm{c}$. Having been unable to establish its identity with any known species, I designate it provisionally Sphenopteris sp. A.

Comparisons. Compared with Sphenopteris sp. A, Senftenbergia plumosa has last order pinnae with higher length/ breadth ratio (7.5-8) and smaller subtriangular pinnules 

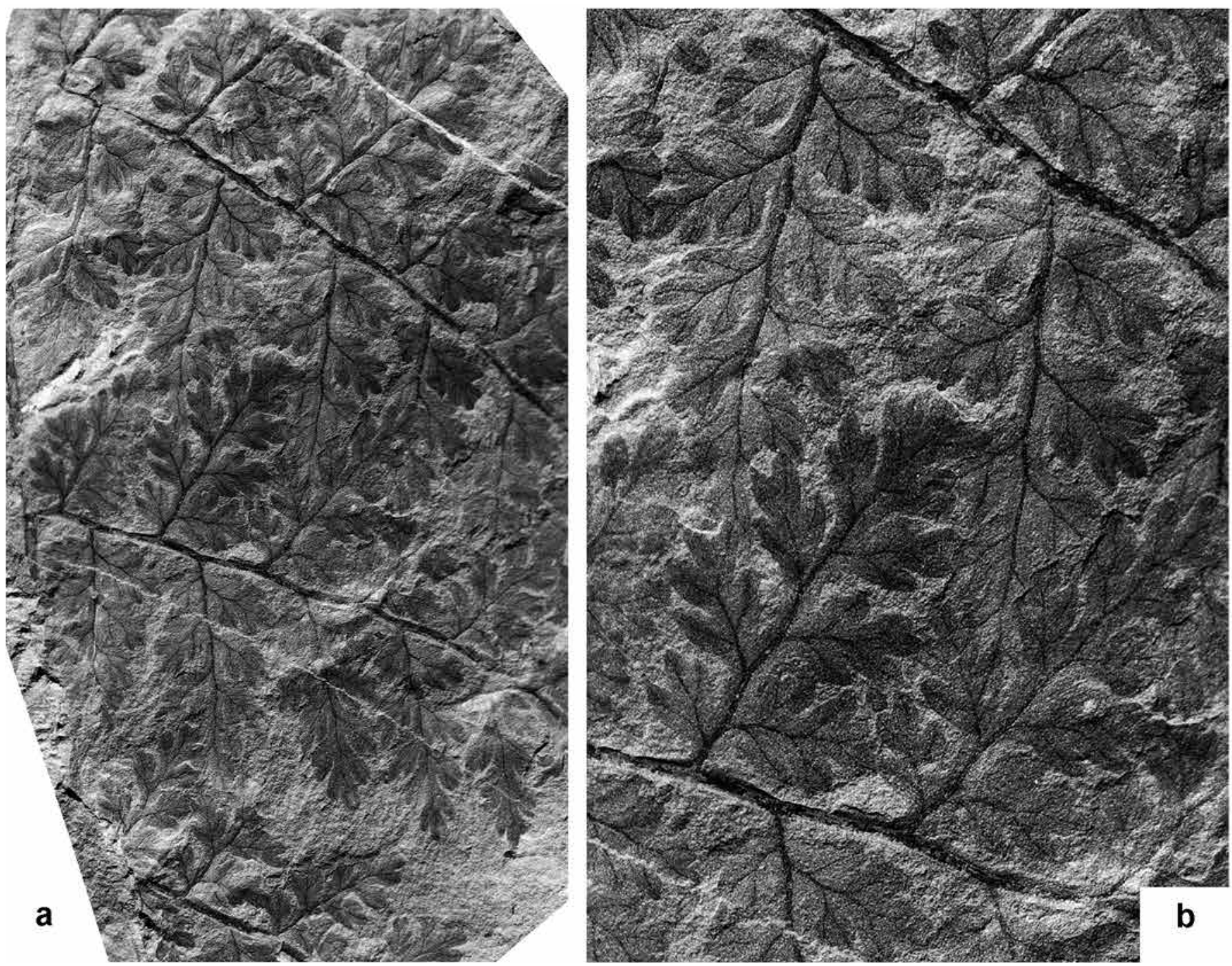

Figure 20. (a) Sphenopteris laciniosa ( $\times$ 3). FGM 999 GF 13.1/21.2. Origin: Spicer's Cove, Nova Scotia. (b) Enlargement $(\times 6)$ of the same specimen. Note basal catadromous pinnules much shorter than the standard laterals, with only three or four lobes. Repository: Fundy Geological Museum, Parrsboro, Nova Scotia.

with entire or slightly crenate margins; the length/breadth ratio for Senftenbergia plumosa is higher (4-6) than for Sphenopteris sp. A. Lateral veins in Senftenbergia plumosa are straight, departing from midrib at a narrow angle; they are simple in smaller pinnules and bifurcate in the larger ones.

Occurrence in the Maritime Provinces, Canada. New BRUNSWICK: locality 273.

\section{Indeterminable fern fragment}

v 1944 Rhodea cf. sparsa, Bell, p. 57, pl. II, fig. 4; pl. XIII, fig. 3.

Remarks. The fragmentary and poorly preserved specimen figured as Rhodea cf. sparsa by Bell (1944, pl. II, fig. 4; pl. XIII, fig. 3) is here regarded as indeterminable. Re-examination of this specimen shows it to consist of two small pinnae with poorly preserved pinnules that certainly do not belong to Rhodea sparsa.

Occurrence in the Maritime Provinces, Canada. Cumberland Basin (Nova Scotia): Bell (1944): locality 1564 (GSC 5938).

\section{SUMMARY AND CONCLUSIONS}

The record of Filicopsida from lower to middle Westphalian strata of Nova Scotia and New Brunswick, eastern Canada, derives from two sources: more or less random collecting during of field mapping by personnel of the Geological Survey of Canada; and material dumped as a result of coal mining. The record is thus incomplete, and most specimens are fragmentary. Early records by Dawson $(1862,1868)$ are particularly fragmentary. Nonetheless, the present revision, 


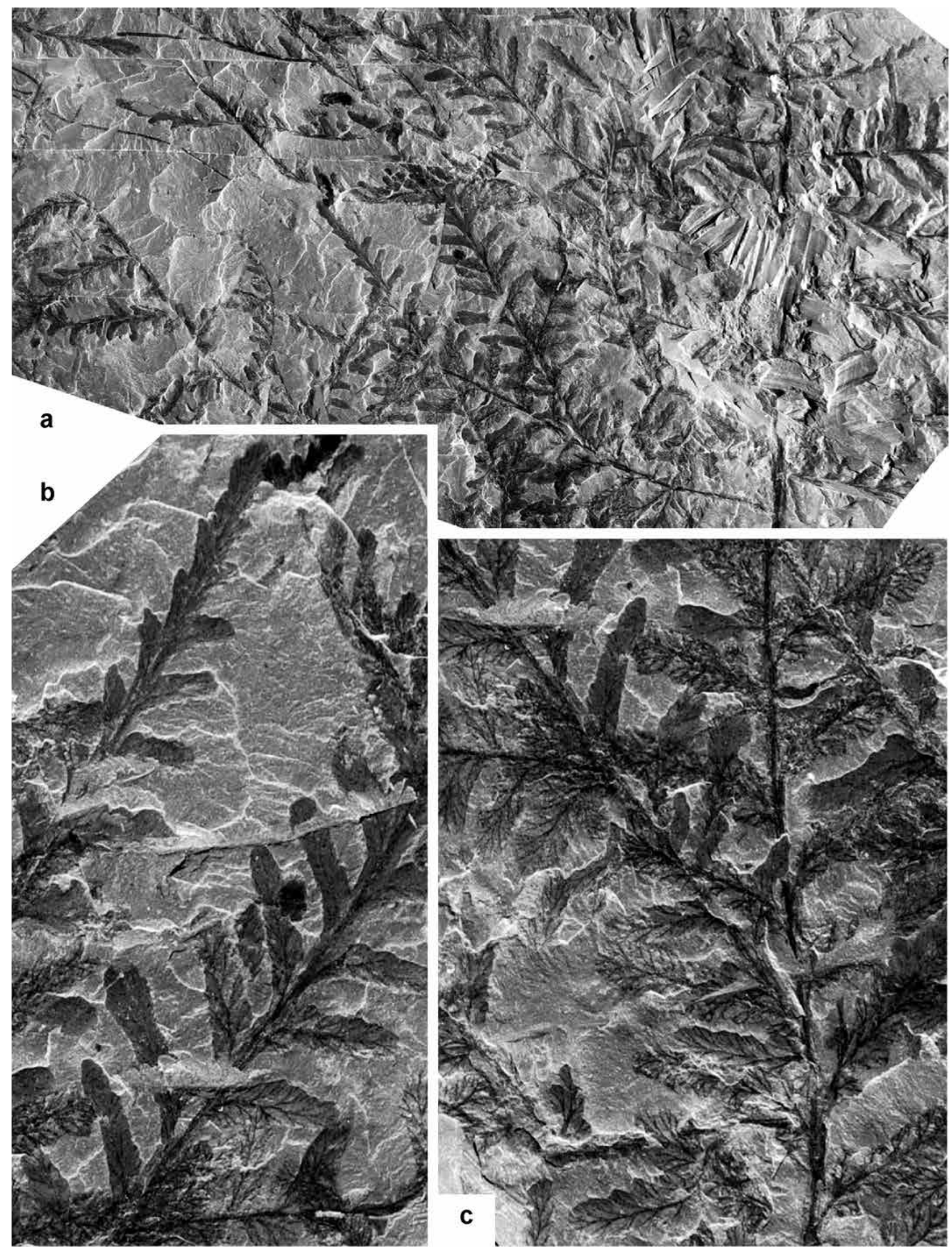


Table 1. List of species figured and described herein in comparison with identifications in Bell (1944) and Dawson $(1862,1868,1871)$.

\begin{tabular}{|c|c|c|}
\hline Present paper & Bell (1944) & Dawson $(1862 / 1868 / 1871)$ \\
\hline Crossotheca crepinii & Sphenopteris philipensis & \\
\hline Zeilleria avoldensis & Pecopteris pilosa (pars) & $\begin{array}{l}\text { Sphenopteris pilosa }+ \text { Callipteris pilosa }+ \\
\text { Pecopteris (Cyathites?) densifolia }\end{array}$ \\
\hline Zeilleria frenzlii & $\begin{array}{l}\text { Zeilleria frenzlii }+ \text { Sphenopteris dixoni }+ \\
\text { Sphenopteris fletcheri }\end{array}$ & \\
\hline Zeilleria hymenophylloides & $\begin{array}{l}\text { Sphenopteris (Zeilleria) hymenophylloides } \\
+ \text { Sphenopteris moyseyi }+ \text { Zeilleria } \\
\text { schaumberg-lippeana }\end{array}$ & \\
\hline Renaultia footneri & Sphenopteris (Renaultia) gracilis & \\
\hline Renaultia rotundifolia & $\begin{array}{l}\text { Sphenopteris (Renaultia) rotundifolia }+ \\
\text { Renaultia hydei }+ \text { Sphenopteris mixta }+ \\
\text { Sphenopteris stipulataeformis }\end{array}$ & Sphenopteris marginata \\
\hline Renaultia schatzlatensis & Sphenopteris deltiformis & \\
\hline Sphyropteris boehnischii Boweria & Rhodea laqueata & \\
\hline schatzlarensis Germera & Boweria schatzlarensis & \\
\hline \multicolumn{3}{|l|}{ mendescorreae sp. nov. } \\
\hline Oligocarpia brongniartii & $\begin{array}{l}\text { Oligocarpia brongniarti }+ \text { Pecopteris } \\
\text { (Senftenbergia?) sp. }\end{array}$ & Sphenopteris splendens \\
\hline Sturia amoena & $\begin{array}{l}\text { Sphenopteris amoenaeformis? + } \\
\text { Sphenopteris (Renautlia?) schatzlarensis } \\
+ \text { Sphenopteris (Zeilleria?) sp. }\end{array}$ & \\
\hline Senftenbergia plumosa & $\begin{array}{l}\text { Pecopteris (Senftenbergia) plumosa forma } \\
\text { crenata }\end{array}$ & $\begin{array}{l}\text { Neuropteris serrulata }+ \text { Pecopteris } \\
\text { (Alethopteris) serrulata }+ \text { Pecopteris } \\
\text { (Alethopteris) preciosa }+ \text { Pecopteris } \\
\text { (Aspidites?) serrulata }+ \text { Pecopteris } \\
\text { (Aspidites?) preciosa }\end{array}$ \\
\hline Alloiopteris almaensis & $\begin{array}{l}\text { Alloiopteris almaensis }+ \text { Alloiopteris } \\
\text { (Corynepteris) coralloides }\end{array}$ & \\
\hline Corynepteris angustissima & $\begin{array}{l}\text { Alloiopteris (Corynepteris) sternbergi }+ \\
\text { Corynepteris sp. }\end{array}$ & \\
\hline \multicolumn{3}{|l|}{ cf. Discopteris vuellersii } \\
\hline Sphenopteris cuneoliformis & Sphenopteris cuneoliformis & \\
\hline Sphenopteris harttii & & $\begin{array}{l}\text { Sphenopteris Harttii }+ \text { Hymenophyllites } \\
\text { curtilobus (pars) }\end{array}$ \\
\hline \multicolumn{3}{|l|}{ Sphenopteris laciniosa } \\
\hline \multicolumn{3}{|l|}{ Sphenopteris sp. A } \\
\hline indet. & Rhodea cf. sparsa & \\
\hline
\end{tabular}

Figure 21. (previous page) (a) Sphenopteris sp. A $(\times 1)$. Specimen without catalogue number. Note the pecopteroid, decurrent pinnules. Origin: New Brunswick (locality 273). (b) Enlargement $(\times 3)$ of part of Fig. 21a to show the elongate, poorly individualized terminal of last order pinna. (c) Another enlargement $(\times 3)$ of the same specimen. Repository: Geological Survey of Canada, Ottawa. 
based mainly on the material recorded by Bell $(1944,1966)$ with additional specimens from the collections of the New Brunswick Museum at Saint John, the Fundy Geological Museum at Parrsboro, and the Joggins Fossil Institute (Donald Reid collection), has yielded a surprisingly large number of fern species. As with other Carboniferous plant groups, most species are the same as those recorded from western Europe, which was palaeogeographically close.

Bell's identifications are generally sound, but some have needed revision, particularly the new species introduced by Bell (1944). Only two of his seven new species, Alloiopteris almaensis and Sphenopteris cuneoliformis, have been provisionally maintained after revision. Both species are based on fragmentary, inadequate specimens, and larger and better preserved material is needed for a better understanding. In addition, only one of the seven species introduced by Dawson, Sphenopteris harttii, is provisionally accepted herein. The other six species are compared with well-known European taxa. Although three of these species were first described by Dawson from Canada, it is necessary to wait the revision of Dawson's material to confirm whether or not they are synonymous.

Table 1 lists the identifications accepted herein in comparison with those in Dawson $(1862,1868,1871)$ and Bell (1944, 1966).

\section{ACKNOWLEDGEMENTS}

John Utting is gratefully acknowledged for the initiative to promote a general revision of lower Westphalian floras in the Maritime Provinces of Canada, an update initiated by Robert H. Wagner in the late 1990s. I want to thank Roberto (Bob) for having infected me with his passion for work, which has allowed me to grow as a person, a palaeobotanist and a geologist. Jean Dougherty, Geological Survey of Canada, Ottawa, and Randall Miller, the New Brunswick Museum, Saint John, provided essential access and data regarding the fossil collections in their institutions. Donald Reid, Joggins Fossil Centre, kindly lent several specimens. The Fundy Geological Museum at Parrsboro lent the specimens from Spicer's Cove. The helpful and well-focused suggestions of the two referees, Stanislav Opluštil and Josef Pšenička are gratefully acknowledged. The meticulous editing by Rob Fensome and all his recommendations to help improve the quality of this contribution are much appreciated.

\section{REFERENCES}

Abbott, M.L. 1954. Revision of the Paleozoic fern genus Oligocarpia. Palaeontographica, Abteilung B, 96, pp. 39-65.

Álvarez Ramis, C. and Doubinger, J. 1973. Sphénoptéridées du Stéphanien français. Comptes rendus du $96^{\mathrm{e}}$ Congrès national des sociétés savantes, Toulouse 1971, section sciences, V, pp. 61-76.

Álvarez Ramis, C., Doubinger, J., and Germer, R. 1978. Die sphenopteridischen Gewächse des Saarkarbons. 1. Teil: Sphenopteris sensu stricto. Palaeontographica, Abteilung B, 165 (1-3), pp. 1-42.

Álvarez Ramis, C., Doubinger, J., and Germer, R. 1979. Die sphenopteridischen Gewächse des Saarkarbons. 2. Teil: Alloiopteris und Palmatopteris. Palaeontographica, Abteilung B, 170 (4-6), pp. 126-150.

Álvarez-Vázquez, C. 1995. Macroflora del Westfaliense inferior de la cuenca de Peñarroya-Belmez-Espiel (Córdoba). Unpublished Ph.D. thesis, Departamento de Geología, Universidad de Oviedo, 393 p.

Álvarez-Vázquez, C. 1999. Nuevos datos aportados por la macroflora a la datación y conocimiento de la cuenca carbonífera de Peñarroya-Belmez-Espiel (Córdoba, SO España). Trabajos de Geología, 21, pp. 37-46.

Álvarez-Vázquez, C. and Wagner, R.H. 2014. Lycopsida from the lower Westphalian (Middle Pennsylvanian) of the Maritime Provinces, Canada. Atlantic Geology, 50, pp. 167-232. https://doi.org/10.4138/atlgeol.2014.011

Álvarez-Vázquez, C. and Wagner, R.H. 2017. A revision of Annularia and Asterophyllites species from the lower Westphalian (Middle Pennsylvanian) of the Maritime Provinces, Canada. Atlantic Geology, 52, pp. 17-62. https://doi.org/10.4138/atlgeol.2017.002

Amerom, H.W.J. van 1975. Die eusphenopteridischen Pteridophyllen aus der Sammlung des geologischen Bureaus in Heerlen, unter besonderer Berücksichtigung ihrer Stratigraphie bezüglich des Südlimburger Kohlenreviers. Mededelingen Rijks Geologische Dienst, C-III-1 (7), pp. 1-208.

Amerom, H.W.J. van 1988. Zeilleria hymenophylloides Kidston, een fossiele varenfructificatie van de steenberg van de voormalige steenkoolmijn Laura \& Vereeniging te Eygelshoven en zijn verspreiding in Zuid-Limburg. (Interessante plantenfossielen uit het Nederlandse Boven-Karboon (I)). Grondboor en Hamer, 42 (3-4), pp. 97-103.

Andrae, C.J. 1865-1869. Vorweltliche Pflanzen aus dem Steinkohlengebirge der preussischen Rheinlande und Westphalens. I (1865): pp. 1-18, Tafn I-IV; II (1866): 1934, Tafn VI-X; III (1869): pp. 35-50, Tafn XI-XV.

Andrews, H.N. 1943. Contributions to our knowledge of American Carboniferous floras. VI. Certain filicinean fructifications. Annals of the Missouri Botanical Garden, 30, pp. 429-443. https://doi.org/10.2307/2394306

Arber, E.A.N. 1916. On the fossil floras of the Coal Measures of south Staffordshire. Philosophical Transactions of the Royal Society of London, Series B, 208, pp. 127155. https://doi.org/10.1098/rstb.1918.0004

Arnold, C.A. 1933. A sphenopterid fructification from the Pennsylvanian of Michigan. The Botanical Gazette, XCIV (4), pp. 821-825. https://doi.org/10.1086/334352

Arnold, C.A. 1937. The seeds of Alethopteris, and other pteridosperms from North America. Compte Rendu $2^{\mathrm{e}}$ Congrès pour l'avancement des études de Stratigraphie Carbonifère, Heerlen 1935, I, pp. 41-45.

Arnold, C.A. 1949. Fossil flora of the Michigan Coal Basin. Contributions from the Museum of Paleontology, 
University of Michigan, VII (9), pp. 131-269.

Artis, E.T. 1825. Antediluvian phytology, as illustrated by a collection of the fossil remains of plants peculiar to the Coal Formation of Great Britain. London, pp. 1-24, pls I-XXIV. https://doi.org/10.5962/bhl.title.119718

Baily, W.H. 1860. On Corynepteris, a new generic form of fossil fern; with observations on the associated plants from the coal-measures of Glin, county of Limerick. Journal of the Geological Society of Dublin, VIII, pp. 237-241.

Bashforth, A.R. 2005. Late Carboniferous (Bolsovian) macroflora from the Barachois Group, Bay St. George Basin, southwestern Newfoundland, Canada. Palaeontographica Canadiana, 24, pp. 1-123.

Basson, P.W. 1968. The fossil flora of the Drywood Formation of southwestern Missouri. University of Missouri Studies, XLIV, pp. 1-170.

Bek, J. and Pšenička, J. 2001. Senftenbergia plumosa (Artis) emend. and its spores from the Carboniferous of the Kladno and Pilsen basins, Bohemian Massif, and some related and synonymous taxa. Review of Palaeobotany and Palynology, 116, pp. 213-232. https://doi.org/10.1016/ S0034-6667(01)00091-4

Bell, W.A. 1938. Fossil flora of Sydney Coalfield, Nova Scotia. Canada Department of Mines and Resources, Mines and Geology Branch, Geological Survey, Memoir 215, pp. 1-334.

Bell, W.A. 1944. Carboniferous rocks and fossil floras of northern Nova Scotia. Canada Department of Mines and Resources, Mines and Geology Branch, Geological Survey, Memoir 238, pp. 1-119. https://doi.org/10.4095/119859

Bell, W.A. 1962. Flora of Pennsylvanian Pictou Group of New Brunswick. Geological Survey of Canada, Department of Mines and Technical Surveys, Bulletin 87, pp. 1-71.

Bell, W.A. 1966. Illustrations of Canadian fossils. Carboniferous plants of eastern Canada. Geological Survey of Canada, Department of Mines and Technical Surveys, Paper 66-11, pls I-XXXVI.

Beltz, G. 1989. Computerunterstützte Revision der Gattung Alloiopteris Potonié (1897). Diplomarbeit zur Geologen-Hauptprüfung, Bonn, 136 p. (Unpublished).

Bertrand, P. 1913. Liste provisoire des Sphenopteris du Bassin houiller du Nord de la France. Annales de la Société Géologique du Nord, XLII, pp. 302-338.

Blake, B.M., Cross, A.T., Eble, C.F., Gillespie, W.H., and Pfefferkorn, H.W. 2002. Selected plant megafossils from the Carboniferous of the Appalachian region, eastern United States: geographic and stratigraphic distribution. In Carboniferous and Permian of the World. Proceedings XIV International Congress Carboniferous and Permian Stratigraphy, Calgary, Alberta 1999. Edited by L.V. Hills, C.M. Henderson, and E.W. Bamber. Canadian Society of Petroleum Geologists, Memoir 19, pp. 259-335.

Boulay, M. 1876. Le terrain houiller du nord de la France et ses végétaux fossiles. Thèse de Géologie, Faculté des Sciences de Caen, Imprimérie Lefebvre-Ducrocq, Lille, 74 p.

Boureau, E. and Doubinger, J. 1975. Traité de paléo- botanique. T. IV, fascicule 2. Pteridophylla (première partie): 1-768, text-figs 1-600. Masson et Cie, Paris.

Brongniart, A. 1822. Sur la classification et la distribution des végétaux fossiles en général, et sur ceux des terrains de sédiment supérieur en particulier. Mémoires Muséum d'Histoire naturelle de Paris, 8, pp. 203-348.

Brongniart, A. 1828a. Prodrome d'une histoire des végétaux fossiles. Paris \& Strasbourg, F.G. Levrault, 225 p.

Brongniart, A. 1828b-1838. Histoire des végétaux fossiles, ou recherches botaniques et géologiques sur les végétaux renfermés dans les diverses couches du globe. Texte: I (1828-1837) - 1 (1828): i-xii, 1-80; 2 (1828): 81-136; 3 (1829): 137-168; 4 (1830): 169-208; 5 (1831): 209-248; 6 (1831): 249-264; 7 (1833): 265-288; 8 (1834): 289-312; 9 (1834): 313-316; 10 (1836): 337-368; 11 (1837): 369-416; 12 (1837): 417-488. II (1837-1838) - 13 (1837): 1-24; 14 (1838): 25-56; 15 (1838): 57-72; Atlas: I - Pls 1-166; II Pls 1-30. Facsimile Edition W. Junk, Berlin (1915).

Brongniart, A. 1849. Tableau des genres de végétaux fossiles considérés sous le point de vue de leur classification botanique et de leur distribution géologique. Dictionnaire universel d'Histoire Naturelle, 13, pp. 1-127.

Brousmiche, C. 1982. Sur la synonymie de Crossotheca boulayi Zeiller, 1886-88 et Crossotheca bourozii Danzé, 1956 avec l'espèce-type du genre: Crossotheca crepinii Zeiller, 1883. Une nouvelle interprétation de la fructification. Geobios, 15 (5), pp. 679-703. https://doi.org/10.1016/ $\underline{\text { S0016-6995(82)80002-8 }}$

Brousmiche, C. 1983. Les fougères sphénoptéridiennes du Bassin Houiller Sarro-Lorrain (systématique - stratigraphie). Société Géologique du Nord, Publication $\mathrm{n}^{\circ}$ 10. Texte: pp. 1-480, text-figs 1-123, tab. 1-26. Atlas: pls $1-100$.

Brousmiche, C. 1986. Précisions sur les spores produites par quelques fougères sphénoptéridiennes appartenant aux genres Boweria Kidston, Crossotheca Zeiller, Discopteris Stur, Myriotheca Zeiller et Urnatopteris Kidston. Revue de Paléobiologie, 5 (2), pp. 231-248.

Brousmiche, C. and Laveine, J.P. 1982. Caractères, répartition et synonymie du Pecopteris avoldensis (Stur) dans le bassin houiller sarro-lorrain. Annales Société Géologique du Nord, CI, pp. 51-63.

Calder, J.H., Gibling, M.R., Scott, A.C., Davies, S.J., and Hebert, B.L. 2006. A fossil lycopsid forest succession in the classic Joggins section of Nova Scotia: paleoecology of a disturbance-prone Pennsylvanian wetland. Geological Society of America, Special Paper 399, pp. 169-195. https://doi.org/10.1130/2006.2399(09)

Canright, J.E. 1959. Fossil plants of Indiana. Indiana Department of Conservation, Geological Survey, Report of Progress 14, pp. 1-45.

Carpentier, A. 1919. Sur les fructifications du Sphenopteris herbacea Boulay. Comptes rendus de l'Académie des Sciences, Paris, 159, pp. 511-513.

Carpentier, A. 1923. Observations sur des fructifications de genre Sphyropteris Stur et de genre Boweria Kidston provenant du Westphalien du Nord de la France. Revue 
Générale de Botanique, XXXV, pp. 3-7.

Carpentier, A. and Depape, G. 1914. Sur quelques Sphenopteris fertiles du Westphalien du nord de la France. Annales de la Société Géologique du Nord, XLIII, pp. 306-322.

Cleal, C.J. 1981. The Ravenhead collection of fossil plants. The Amateur Geologist, IX (11), pp. 12-23.

Cleal, C.J. 1992. Paleobotany. Encyclopedia of Earth System Science, 3, pp. 531-542.

Cleal, C.J. 1993. Plants. 44. Gymnospermophyta. In The fossil record 2. Edited by M.J. Benton. The Palaeontological Association, pp. 795-808. Chapman \& Hall, London.

Cleal, C.J., Fraser, H.E., Lazarus, M., and Dannell, G. 2009. The forests before the flood: the palaeobotanical contributions of Edmund Tyrell Artis (1789-1874). Earth Sciences History, 28 (2), pp. 245-275. https://doi.org/10.17704/ eshi.28.2.31w8363563403478

Copeland, E.B. 1947. Genera filicum. Chronica Botánica. Waltham, Massachusetts, $247 \mathrm{p}$.

Corda, A.J. 1845. Beiträge zur Flora der Vorwelt. Prague, 128 p. https://doi.org/10.5962/bhl.title.141710

Corsin, P. 1927. Sur la position systématique du Zeilleria avoldensis Stur. Annales de la Société Géologique du Nord, LII, pp. 28-35.

Corsin, P. 1932. Guide paléontologique dans le terrain houiller du nord de la France. Travaux et Mémoires de l'Université de Lille, 5, pp. 1-44.

Corsin, P. 1951. Bassin houiller de la Sarre et de la Lorraine. I. Flore fossile. $4^{\text {me }}$ fascicule. Pécoptéridées. Études des Gîtes minéraux de la France, pp. 177-370, pls CVIIICXCIX.

Crépin, F. 1880. Notes paléophytologiques. Deuxième note. I. Observations sur quelques Sphenopteris et sur les côtes des Calamites. Bulletin de la Société Royale de Botanique de Belgique, 20 (2), pp. 13-19.

Cridland, A.A., Morris, J.E., and Baxter, R.W. 1963. The Pennsylvanian plants of Kansas and their stratigraphic significance. Palaeontographica, Abt. B, 112 (1-3), pp. 58-92.

Crookall, R. 1930. Crossotheca and Lyginopteris oldhamia. Annals of Botany, XLIV (CLXXV), pp. 621-637. https:// doi.org/10.1093/oxfordjournals.aob.a090240

Cross, A.T. 1958. The geology and mineral resources of Athens County, Ohio. Ohio Department of Natural Resources, Division of Geological Survey, Bulletin 57, pp. 1-218.

Cross, A.T., Gillespie, W.H., and Taggart, R.E. 1996. Upper Paleozoic vascular plants. In Fossils of Ohio. Edited by R.M. Feldmann, R.M. and M. Hackathorn. Department of Natural Resources, Division of Geological Survey, Bulletin 70, pp. 396-479.

Dalinval, A. 1960. Contribution à l'étude des Pécoptéridées. Les Pecopteris du bassin houiller du nord de la France. I. Flore Fossile, $3^{\circ}$ fascicule. Études géologiques pour l'Atlas de Topographie souterraine publiées par le Service Géologique des H.B.N.P.C., Houillères du Bassin du Nord et du Pas-de-Calais. Texte: pp. 1-222. Atlas: pls I-LXI.

Danzé, J. 1956. Contribution a l'étude des Sphenopteris.
Les fougères sphénoptéridiennes du bassin houiller du Nord de la France. I. Flore fossile, $2^{\mathrm{e}}$ fascicule. Études géologiques pour l'Atlas de Topographie souterraine, Service Géologique des H.B.N.P.C. Texte: pp. 1-568, text-figs 1-67. Atlas: pls I-LXXXVI.

Darrah, W.C. 1969. A critical review of the Upper Pennsylvanian floras of eastern United States with notes on the Mazon Creek Flora of Illinois. Privately printed, Catalog Card Number 74-113602, Library of Congress, Washington, $220 \mathrm{p}$.

Dawson, J.W. 1862. On the flora of the Devonian Period in north-eastern America. Quarterly Journal of the Geological Society of London, XVIII, pp. 296-330. https://doi. org/10.1144/GSL.JGS.1862.018.01-02.42

Dawson, J.W. 1868. Acadian Geology. The geological structure, organic remains, and mineral resources of Nova Scotia, New Brunswick, and Prince Edward Island. London ( $2^{\text {nd }}$ edition, 1891), $694 \mathrm{p}$.

Dawson, J.W. 1871. The fossil plants of the Devonian and Upper Silurian formations. Geological Survey of Canada, Report, 92 p. https://doi.org/10.4095/216073

Dawson, J.W. 1888. The geological history of plants. London, 290 p. (reissued in 1905).

DiMichele, W. and Dolph, G. 1981. Compression floras of the Upper Mansfield/Lower Brazil and Upper Staunton Formation in Parke and Clay counties, Indiana. Thirty-second Annual AIBS Meeting, Field Trip 2, Guidebook to Pennsylvanian Plant Localities, pp. 1-6.

DiMichele, W.A., Bashforth, A.R., Eble, C.F., and Nelson, W.J. 2016. A Middle Pennsylvanian (early Asturian) tropical dry forest, Atokan-Desmoinesian boundary, Illinois Basin, USA. Spanish Journal of Palaeontology, 33 (1), pp. 41-84.

DiMichele, W.A., Chaney, D.S., Lucas, S.G., Nelson, W.J., Elrick, S.D., Falcon-Lang, H.J., and Kerp, H. 2017. Middle and Late Pennsylvanian fossil floras from Socorro County, New Mexico, U.S.A. In Carboniferous-Permian transition in Socorro County, New Mexico. Edited by S.G. Lucas, W.A. DiMichele, and K. Krainer. New Mexico Museum of Natural History and Science Bulletin, 77, pp. 25-100.

Doubinger, J. 1959. Remarques sur les Sphenopteris du Stéphanien. Bulletin de la Société d'Études Scientifiques d'Angers, Nouvelle Série, II, 89e Année, pp. 114-116.

Doubinger, J. and Germer, R. 1971. Neue Pecopteridenfunde im Saarkarbon. Palaeontographica, Abt. B, 133 (1-3), pp. 72-88.

Doubinger, J. and Germer, R. 1975. Description de quelques frondes sphénoptéridiennes du Carbonifère Sarro-Lorrain. Comptes Rendus du 99e Congrès national des sociétés savantes, Besançon 1974, section sciences, II, pp. 373-381.

Eggert, D.A. and Delevoryas, T. 1967. Studies of Paleozoic ferns: Sermaya, gen. nov. and its bearing on filicalean evolution in the Paleozoic. Palaeontographica, Abt. B, 120, pp. 169-180.

Eggert, D.A. and Taylor, T.N. 1966. Studies of Paleozoic 
ferns: on the genus Tedelea gen. nov. Palaeontographica, Abt. B, 118 (1-3), pp. 52-73.

Ettingshausen, C. von 1854. Die Steinkohlenflora von Radnitz in Böhmen. Abhandlungen der kaiserlichen-königlichen geologischen Reichsanstalt, III (3), pp. 1-74.

Frojdová, J., Pšenička, J., and Bek, J. 2017a. Revision of Pennsylvanian genus Sturia Němejc and its spores (Duckmantian, Czech Republic). Acta Palaeobotanica, 57 (2), pp. 153-163. https://doi.org/10.1515/acpa-2017-0014.

Frojdová, J., Pšenička, J., Bek, J., and Cleal, C.J. 2017b. Revision of the Pennsylvanian fern Boweria Kidston and the establishment of the new genus Kidstoniopteris. Review of Palaeobotany and Palynology, 236, pp. 33-58. https://doi. org/10.1016/j.revpalbo.2016.08.011

Galtier, J. and Scott, A.C. 1979. Studies of Paleozoic ferns: On the genus Corynepteris. A redescription of the type and some other European species. Palaeontographica, Abt. B, 170 (4-6), pp. 81-125.

Geinitz, H.B. 1855. Die Versteinerungen der Steinkohlenformation in Sachsen. Leipzig, $61 \mathrm{p}$.

Germar, E.F. 1848. Die Versteinerungen des Steinkohlengebirges von Wettin und Löbejün im Saalkreise. Teil 5, pp. 40-42. Halle.

Gillespie, W.H. and Crawford, T.J. 1985. Plant megafossils from the Carboniferous of Georgia, U.S.A. Compte Ren$\mathrm{du} 10^{\text {ième }}$ Congrès International de Stratigraphie et de Géologie du Carbonifère, Madrid 1983, 2, pp. 247-256.

Gillespie, W.H. and Latimer, I.S. 1960. A guide to the common fossil plants of West Virginia. West Virginia Geological and Economic Survey, Educational Series, June 1960, pp. 1-59.

Gillespie, W.H., Latimer, I.S., and Clendening, J.A. 1966. Plant fossils of West Virginia. West Virginia Geological and Economic Survey, Educational Series, pp. 1-131.

Gillespie, W.H., Clendening, J.A., and Pfefferkorn, H.W. 1978. Plant fossils of West Virginia and adjacent areas. West Virginia Geological and Economic Survey, Educational Series ED-3A, pp. 1-172.

Gillespie, W.H., Crawford, T.J., and Waters, J.A. 1989. Plant fossils of the Pennsylvanian System of Georgia. $38^{\text {th }}$ Annual Meeting, Southeastern Section, Geological Society of America, Guidebook Addendum, pp. 1-13.

Göppert, H.R. von 1836. Die Fossilen Farnkräuter. Verhandlungen der Kaiserlichen Leopoldinisch-Carolinischen Akademie der Naturforscher, XXII Supplement, pp. 1-299.

Göppert, H.R. von 1841-1846. Die Gattungen der fossilen Pflanzen verglichen mit denen der Jetztwelt und durch Abbildungen erläutert. Verlag Henry \& Cohen, Bonn, $151 \mathrm{p}$.

Göppert, H.R. von 1852. Fossile Flora des Übergangsgebirges. Verhandlungen der kairserlichen Leopoldinisch-Carolinischen Akademie der Naturforscher. Breslau und Bonn, $299 \mathrm{p}$.

Göppert, H.R. 1864-1865. Die fossile Flora der Permischen Formation. Beiträge zur Naturgeschichte der Vorwelt. Palaeontographica, 12, pp. 1-316.
Gothan, W. 1912. Einige bemerkenswerte neuere Funde von Steinkohlenpflanzen in der Dortmunder Gegend. Verhandlungen des Naturhistorischen Vereins der preussischen Rheinlande und Westfalens, 69, pp. 239-253.

Gothan, W. 1913. Die Oberschlesische Steinkohlenflora. I. Farne und farnähnliche Gewächse (Cycadofilices bezw. Pteridospermen). Abhandlungen der Königlichen Preussischen Geologischen Landesanstalt, (N.F.), 75, pp. 1-278.

Gothan, W. 1931. Die Steinkohlenflora der westlichen paralischen Carbonreviere Deutschlands. Institut für Paläobotanik und Petrographie der Brennsteine, Preussische Geologische Landesanstalt, 1 (2), pp. 50-96.

Gothan, W. 1935. Die Steinkohlenflora der westlichen paralischen Steinkohlenreviere Deutschlands (4. Lieferung). Abhandlungen der Preussischen Geologischen Landesanstalt (N.F.), 167, pp. 1-58.

Gothan, W. 1941. Die Steinkohlenflora der westlichen paralischen Steinkohlenreviere Deutschlands (4. Lieferung). Abhandlungen Reichsstelle für Bodenforschung (N.F.), 196, pp. 1-54.

Gothan, W. and Jongmans, W.J. 1915. Bemerkungen über einige der in den niederländischen Bohrungen gefundenen Pflanzen. In Paläobotanisch-stratigraphische Studien im Niederländische Carbon nebst Vergleichen mit umliegenden Gebieten. Königlich Preussischen Geologischen Landesanstalt, 18, pp. 159-183.

Grand'Eury, C. 1877. Flore Carbonifère du Département de la Loire et du centre de la France. Prèmiere partie. Mémoires Académie des Sciences de l'Institut de France, XXIV, $624 \mathrm{p}$.

Gutbier, A. 1835. Abdrücke und Versteinerungen des Zwickauer Schwarzkohlengebirges und seiner Umgebungen. Zwickau, 80 p. https://doi.org/10.5962/bhl.title.152878

Gutbier, A. 1843. Gäa von Sachsen. Dresden und Leipzig, pp. 67-93.

Guthörl, P. 1943. Pflanzenreste aus den Rothell-Aufschlüssen der Grube St. Ingbert-Saar und ihre Bedeutung für die Stratigraphie und Tektonik des Saarkarbons. Palaeontographica, Abt. B, LXXXVII, pp. 137-153.

Higgins, H.H. 1872. On some fossil ferns in the Ravenhead Collection, Free Public Museum, Liverpool. Proceedings of the Liverpool Geological Society, $13^{\text {th }}$ Session, 2, pp. 94-96.

Hirmer, M. 1927. Handbuch der Paläobotanik. Band I: Thallophyta-Bryophyta-Pteridophyta. Verlag R. Oldenbourg, München und Berlin, 708 p.

Janssen, R.E. 1957. Leaves and stems from fossil forests. A Handbook of the Paleobotanical Collections in the Illinois State Museum. Illinois State Museum, Popular Science Series, I, 190 p. (First Printing, 1939).

Jennings, J.R. 1975. Lower Pennsylvanian plants of Illinois. II: Structurally preserved Alloiopteris from the Drury Shale. Journal of Paleontology, 49 (1), pp. 52-57.

Jennings, J.R. 1984. Distribution of fossil plant taxa in the Upper Mississippian and Lower Pennsylvanian of the Illinois Basin. Compte Rendu 9e Congrès International 
de Stratigraphie et Géologie du Carbonifère, Washington and Champaign-Urbana 1979, 2, pp. 301-312.

Jongmans, W.J. 1926. Eigenaardige plantenbank boven Lg. B, S.M. Emma, Jaarverslag, Geologisch Bureau, Heerlen, p. 49.

Jongmans, W.J. 1928. Stratigraphie van het Karboon in het algemeen en van Limburg in het bijzonder. Geologisch Bureau, Mededeeling, 6, pp. 1-50.

Jongmans, W.J. 1937. Comparison of the floral sucession in the Carboniferous of West Virginia with Europe. Compte Rendu $2^{\mathrm{e}}$ Congrès pour l'avancement des études de Stratigraphie Carbonifère, Heerlen 1935, I, pp. 393-415.

Jongmans, W.J. 1951. The female fructification of Sphenopteris hoeninghausi and the (supposed) relation of this species with Crossotheca. The Palaeobotanist, 1, pp. 267-276.

Josten, K.-H. 1983. Die fossilen Floren im Namur des Ruhrkarbons. Fortschritte Geologie von Rheinland und Westfalen, 31. Textband: pp. 1-327; Tafelband: 1-112.

Josten, K.-H. 1991. Die Steinkohlen-Floren Nordwestdeutschlands. Fortschritte Geologie von Rheinland und Westfalen, 36. Textband: pp. 1-434; Tafelband: 1-220.

Kidston, R. 1884. On the fructification of Zeilleria (Sphenopteris) delicatula, Sternb., sp.; with remarks on Urnatopteris (Sphenopteris) tenella, Brongt., and Hymenophyllites (Sphenopteris) quadridactylites, Gutbier, sp. Quarterly Journal of the Geological Society, London, XL, pp. 590598. https://doi.org/10.1144/GSL.JGS.1884.40.01-04.49

Kidston, R. 1886. Catalogue of the Palaeozoic plants in the Department of Geology and Palaeontology, British Museum (Natural History). Harrison and Sons, London, 288 p.

Kidston, R. 1888. On the fructification of two Coal-Measure ferns. Annals and Magazine of Natural History, Serie B, 2, pp. 22-27. https://doi.org/10.1080/00222938809460871

Kidston, R. 1889. On the fossil plants in the Ravenhead Collection in the Free Library and Museum, Liverpool. Transactions of the Royal Society of Edinburgh, XXXV, part II (10), pp. 391-417.

Kidston, R. 1890. The Yorkshire Carboniferous flora. First report. Transactions of the Yorkshire Naturalists' Union, 14 (for 1888), pp. 1-65.

Kidston, R. 1893. The Carboniferous flora of Yorkshire. Fourth report. On behalf of the Yorkshire Fossil Flora Committee for 1892. Transaction of the Yorkshire Naturalists' Union, 18, pp. 97-122.

Kidston, R. 1896. On the fossil flora of the Yorkshire Coal Field. (First paper.) Transactions of the Royal Society of Edinburgh, XXXVIII, part II (5), pp. 203-223.

Kidston, R. 1911. Les végétaux houillers recueillis dans le Hainaut belge et se trouvant dans les collections du Musée royal d'Histoire naturelle à Bruxelles. Imprimerie Polleunis \& Ceuterick, Bruxelles, $282 \mathrm{p}$.

Kidston, R. 1914. On the fossil flora of the Staffordshire Coal Fields. Part III.- The fossil flora of the Westphalian Series of the South Staffordshire Coal Field. Transactions of the Royal Society of Edinburgh, L, part I (5), pp. 73-199. Kidston, R. 1917. The fossil plants of the Titterstone Clee
Hill Coal Fields. In The Forest of Wyre and the Titterstone Clee Hill coal fields. Edited by R. Kidston, T.C. Cantrill, and E.E.L. Dixon. Transactions of the Royal Society of Edinburgh, LI, Part IV (27), pp. 999-1084.

Kidston, R. 1923-1925. Fossil plants of the Carboniferous rocks of Great Britain. Memoirs Geological Survey of Great Britain, Palaeontology, II. Part 1 (1923): pp. 1-110, pls I-XXII, pls A-E; Part 2 (1923): pp. 111-198, pls XXIII-XLVII; Part 3 (1923): pp. 199-274, pls XLVIIILXVIII; Part 4 (1923): pp. 275-376, pls LXIX-XCI; Part 5 (1924): pp. 377-522, pls XCII-CXXII; Part 6 (1925): pp. 523-670, pls CXXIII-CLIII.

Kotasowa, A. 1968. The flora of the productive Carboniferous in the north-eastern part of the Upper Silesian Coal Basin (Dąbrowa District). Instytut Geologiczny Prace, LII, pp. 1-88. (In Polish with English summary).

Kvaček, J. and Straková, M. 1997. Catalogue of fossil plants described in works of Kaspar M. Sternberg. National Museum, Prague, $201 \mathrm{p}$.

Langford, G. 1958. The Wilmington Coal Flora from a Pennsylvanian deposit in Will County, Illinois. Earth Science Club of Northern Illinois, Esconi Associates, Illinois, $360 \mathrm{p}$.

Laveine, J.-P. 1970. Quelques pécoptéridinées houillères à la lumière de la palynologie (II). Implications paléobotaniques et stratigraphiques. Pollen et Spores, XII (2), pp. 235-297.

Lesquereux, L. 1879-1884. Description of the Coal Flora of the Carboniferous Formation in Pennsylvania and throughout the United States. Second Geological Survey of Pennsylvania, Report of Progress. Text - I (1880): pp. 1-354; II (1880): pp. 355-694, i-lxiii, pls LXXXVI, LXXXVII; III (1884): pp. 695-977, pls LXXXVIII-CXI. Atlas (1879): pls A, B; pls I-LXXXV.

Lindley, J. and Hutton, W. 1831-1837. The fossil flora of Great Britain; or, figures and descriptions of the vegetable remains found in a sossil state in this country. I (18311833) - 1831: pp. 1-47, pls 1-14; 1832: pp. 48-166, pls 15-59; 1833: pp. 167-224, pls 60-79; II (1833-1835)1833: pp. 1-56, pls 80-99; 1834: pp. 57-156, pls 100-137; 1835: pp. 157-208, pls 138-156; III (1835-1837) - 1835: pp. 1-72, pls 157-176; 1836: pp. 73-122, pls 177-194; 1837: pp. 123-208, pls 195-230. James Ridgway and Sons, London.

Lyons, P.C., Zeissner, Ch.R., Barwood, H.L., and Adinolfi, F.G. 1985. North American and European megafloral correlations with the upper part of the Pottsville Formation of the Warrior coal field; Alabama, U.S.A. Compte Rendu $10^{\mathrm{e}}$ Congrès International de Stratigraphie et Géologie du Carbonifère, Madrid 1983, 2, pp. 203-245.

Marrat, F.P. 1872. On the fossil ferns in the Ravenhead Collection. Proceedings of the Liverpool Geological Society, III, pp. 4-40.

Matthews, G.F. 1910. The oldest Silurian flora. Bulletin of the Natural History Society of New Brunswick, XXVIII, VI (II), pp. 241-250.

Meyen, S.V. 1987. Fundamentals of palaeobotany. Chapman 
and Hall Ltd., London \& New York, 432 p. https://doi. org/10.1007/978-94-009-3151-0

Němejc, F. 1928. Some new interesting discoveries of plantimpressions in the coalbasins of Central Bohemia. Bulletin international de l'Académie des Sciences de Bohême, pp. 1-10.

Němejc, F. 1934. On two new Sphenopteris fructifications closely allied to Kidston's Boweria (resp. Scott's Pteridotheca) with remarks to some of the already known Palaeozoic fern sporangia. Věstník Královské České Společnosti Nauk, II, pp. 1-17.

Němejc, F. 1937. The Sphenopterides stated in the Permocarboniferous of central Bohemia. (A preliminary report I. part.) Věstník Královské České Společnosti Nauk, II, pp. 1-24.

Němejc, F. 1938. A revision of the Carboniferous and Permian floras of the coal-districts of central Bohemia (Part II. Sphenopterides: A. Coenopteridae). Palaeontographica Bohemica, XVI, pp. 1-56.

Němejc, F. 1940. The Pecopterides of the coal districts of Bohemia. (A preliminary study.) Acta Musei Nationalis Pragae, Geologia et Paleontologia, IIB (1), pp. 1-28.

Němejc, F. 1963. Paleobotanika. II. Nakladatelství Československé Akademie Věd, Praha, 529 p.

Noé, A.C. 1925. Pennsylvanian flora of northern Illinois. Illinois State Geological Survey, Bulletin, 52, pp. 1-113.

Oleksyshyn, J. 1982. Fossil plants from the anthracite coal fields of eastern Pennsylvania. Pennsylvania Geological Survery, General Geology Report 72, pp. 1-157.

Opluštil, S., Pšenička, J., Šimůnek, Z., and Libertín, M. 2016. Floras of clastic and peat-forming Pennsylvanian wetlands: are they different? A case study from the Upper Radnice Coal (late Duckmantian), Kladno Coalfield, Czech Republic. Spanish Journal of Palaeontology, 31 (1), pp. $145-180$.

Pfefferkorn, H.W. 1978. Revision der Sphenopteriden Discopteris karwinensis Stur, Discopteris vuellersi Stur und der Gattung Discopteris Stur. Argumenta Palaeobotanica, 5, pp. 167-193.

Potonié, H. 1890. Ueber einige Carbonfarne. Jahrbuch der Königlich Preussischen geologischen Landesanstalt und Bergakademie zu Berlin, für Jahr 1889, pp. 21-27.

Potonié, H. 1892. Ueber einige Carbonfarne, III. Abhandlungen der Königlich Preussischen geologischen Landesanstalt und Bergakademie zu Berlin, für Jahr 1891, XII, pp. 1-36.

Potonié, H. 1893. Ueber das Rothliegende des Thüringer Waldes. Theil II: Die Flora des Rothliegenden von Thüringen. Abhandlungen der Königlich Preussischen geologischen Landesanstalt. Neue Folge 9, pp. 1-298.

Potonié, H. 1896. Die floristische Gliederung des deutschen Carbon und Perm. Königlich Preussischen geologischen Landesanstalt, Neue Floge, 21, pp. 1-58.

Potonié, H. 1897. Lehrbuch der Pflanzenpalaeontologie. Berlin, $402 \mathrm{p}$.

Potonié, H. 1899. Lehrbuch der Pflanzenpalaeontologie mit besonderer Rücksicht auf die Bedürfnisse des Geologen.
Berlin, $402 \mathrm{p}$.

Pšenička, J. and Bek, J. 2003. Cuticles and spores of Senftenbergia plumosa Bek and Pšenička from the Carboniferous of Pilsen Basin, Bohemian Massif. Review of Palaeobotany and Palynology, 125, pp. 299-312. https://doi. org/10.1016/S0034-6667(03)00006-X

Pšenička, J. and Opluštil, S. 2011. Fossil flora from the Ujezd u Svatého Křiže Coalfield (Bolsovian, Pennsylvanian), Radnice Basin, Czech Republic. Folia, 45 (1-2), pp. 61-93.

Radforth, N.M. 1937-1938. An analysis and comparison of the structural features of Dactylotheca plumosa Artis sp. and Senftenbergia ophiodermatica Göppert sp. Transactions of the Royal Society of Edinburgh, LIX (II), 14, pp. 385-396.

Radforth, N.M. 1938-1939. Further contributions to our knowledge of the fossil Schizaeaceae; genus Senftenbergia. Transactions of the Royal Society of Edinburgh, LIX (III), 27, pp. 745-761.

Remy, W. and Remy, R. 1959. Pflanzenfossilien. Ein Führer durch die Flora des limnisch entwickelten Paläozoikums. Akademie Verlag, Berlin, 285 p.

Rydzewski, B. 1913. Sur l'âge des couches houillères du bassin carbonifère de Cracovie. Bulletin Académie des sciences de Cracovie, Série B: Sciences naturelles, pp. 538-565.

Schimper, W.P. 1869-1874. Traité de paléontologie végétale ou la flore du Monde Primitif dans ses rapports avec les formations géologiques et la Flore du Monde Actuel. Texte - I (1869): pp. 1-738; II (1870-72): pp. 1-966; III (1874): pp. 1-896; Atlas (1874): pls I-CX. J.B. Baillière et Fils, Paris.

Schlotheim, E.F. von 1804. Beschreibungen merkwürdiger Kräuterabdrücke und Pflanzen-Versteinerungen. Ein Beitrag zur Flora der Vorwelt, Erste Abteilung. Gotha, pp. 1-68.

Simson-Scharold, E. 1934. Zur Kenntnis der Carbonflora des Saargebietes. Palaeontographica, Abt. B, LXXIX, pp. 1-66.

Skog, J.E., Andrews, H.N., and Mamay, S.H. 1969. Canipa quadrifida, gen. et sp. nov., a synangial fructification from the Middle Pennsylvanian of West Virginia. Bulletin of the Torrey Botanical Club, 96 (3), pp. 276-287. https:// doi.org/10.2307/2483734

Sternberg, K. von 1820-1838. Versuch einer geognostisch-botanischer Darstellung der Flora der Vorwelt. I (1820-1825) 1 (1820): pp. 1-24, Tafn I-XIII; 2 (1821): pp. 1-33, Tafn XIV-XXVI; 3 (1823): pp. 1-40, Tafn XXVIIXXXIX; 4 (1825): pp. 1-48, Tafn XL-LIX, Tafn A-E. II (1833-1838) - 5/6 (1833): pp. 1-80, Tafn I-XXVI; 7/8 (1838, Presl): pp. 81-220, Tafn I-LXVIII, Tafn A, B (incl. Corda: Skizzen zur vergleichenden Phytotomie vor- und jetztweltlicher Pflanzenstämme, I-LXXI).

Sterzel, J.T. 1881. Paläontologischer Charakter der oberen Steinkohlenformation und des Rotliegenden im erzgebirgischen Becken. Bericht der Naturwissenschaftlichen Gesellschaft zu Chemnitz, 7, pp. 155-270.

Sterzel, J.T. 1901. Die Flora des Rothliegenden von Ilfeld an 
der Harz. Centralblatt für Mineralogie, Geologie und Palaeontologie, pp. 417-427.

Stockmans, F. and Willière, Y. 1958. Un beau toit à végétaux au siège Fiestaux des Charbonnages de MonceauFontaine (Zone de Genk, partie supérieur). In Le Massif du Carabinier dans la Division Marcinelle des Charbonnages de Monceau-Fontaine. Edited by B.M. Aderca. Association pour l'Étude de la Paléontologie et de la Stratigraphie houillères, Bruxelles, 34, pls I-XI.

Stockmans, F. and Willière, Y. 1965. Documents paléobotaniques pour l'étude du houiller dans le nord-ouest de l'Espagne. [Documentos paleobotánicos para el estudio de la geología hullera del noroeste de España]. Mémoires, Institut Royal des Sciences Naturelles de Belgique, Deuxième Série, fasc. 79, pp. 1-92.

Stockmans, F. and Willière, Y. 1966. Étude paléobotanique du toit de la veine Cinq Paumes (Gros Pierre) aux charbonnages de Boubier (Basin de Charleroi). Centre national de Géologie houillère, 11, pp. 1-13.

Stopa, S.Z. 1957. Les feuilles de fougères (Pteridophylla) du Namurien supérieur et du Westphalien le plus bas dans le bassin houiller de la Haute Silésie. Instytut Geologiczny, Prace, XIII, pp. 1-208. (In Polish with French summary).

Stopes, M.C. 1914. The "Fern Ledges" Carboniferous flora of St. John, New Brunswick. Geological Survey of Canada, Memoir 41 (38 of Geological Series), pp. 1-142, pls I-XXV. (Traduction française 1917. Flore carbonifère des "assises à fougères" de Saint-Jean, Nouveau-Brunswick. Geological Survey of Canada, Memoir 41).

Stur, D. 1877. Die Culm-Flora der Ostrauer und Waldenburger Schichten. Abhandlungen der kaiserlichen-königlichen geologischen Reichsanstalt, VIII, pp. 1-366, Tafn I-XXVII (XVIII-XLIV).

Stur, D. 1883. Zur Morphologie und Systematik der Culmund Carbonfarne. Sitzberichte königlichen Akademie der Wissenschaften, I Abtheilung, LXXXVIII, pp. 633-846 (1-214).

Stur, D. 1885. Beiträge zur Kenntniss der Flora der Vorwelt. Band II. Die Carbon-Flora der Schatzlarer Schichten. Abh. I: Die Farne der Carbon-Flora der Schatzlarer Schichten. Abhandlungen der kaiserlichen-königlichen geologischen Reichsanstalt, XI. Text: pp. 1-418, textfigs 1-48. Tafel-Erklärung: Tafn I-IIb; III-IVb; V-VIIb; VIII-XIb; XII, XIIb, XIII, XIIIb, XIV, XIVb, XV, XVb, XVI, XVIb, XVII.

Suckow, G.A. 1784. Beschreibung einiger merkwürdiger Abdrücke von der Art der sogenannten Calamiten. Acta Academiae Theodoro-Palatinae, V, Pars Physica, pp. 166-200.

Šusta, V. 1928. Stratigraphie des Ostrau-Karviner Steinkohlenreviers im Lichte der Paläontologie. In Der Kohlenbergbau des Ostrau-Karviner Steinkohlenreviers (Direcktoren-Konferenz des Ostrau-Karviner Steinkohlenreviers in Mährisch Ostrau im Zehnten Jahre der Čechoslovakischen Republik), pp. 381-484, Tafn ILXXIV.

Teixeira, C. 1939. Contribuição para o estudo do Estefaniano dos arredores do Pôrto. Publicações do Museu e
Laboratório Mineralógico e Geológico da Faculdade de Ciências do Pôrto, XI, pp. 1-24.

Thomas, B.A. and Crampton, D.M. 1971. A fertile Zeilleria avoldensis from the British Upper Carboniferous. Review of Palaeobotany and Palynology, 11, pp. 283-295. https:// doi.org/10.1016/0034-6667(71)90008-X

Tidwell, W.D. 1967. Flora of Manning Canyon Shale. Part I: a lowermost Pennsylvanian flora from the Manning Canyon Shale, Utah, and its stratigraphic significance. Brigham Young University Geology Studies, 14, pp. 1-66.

Tidwell, W.D. 1975. Guide to the common fossil plants of western North America. Brigham Young University Press, Utah, 197 p. (Second edition, 1998, 299 p.).

Unger, F. 1850. Genera et species plantarum fossilium. Akademie der Wissenschaften, Vienna, $627 \mathrm{p}$.

Vetter, P. 1968. Géologie et paléontologie des bassins houillers de Decazeville, de Figeac et du Détroit de Rodez. I. Description géologique, pp. 1-442. II. Étude paléontologique, pp. 1-194, pls I-XLIX. Houillères du Bassin d'Aquitaine, Albi.

Wagner, R.H. 1965. Palaeobotanical dating of Upper Carboniferous folding phases in NW. Spain. Memorias del Instituto Geológico y Minero de España, LXVI, pp. 1-169.

Wagner, R.H. 1987. La Paleobotánica Hullera, sus aspectos botánicos, estratigráficos y paleogeográficos, floras neopaleozoicas del SW de España. Acto de Investidura del grado de Doctor Honoris Causa, Universidad de Córdoba. Diciembre 1985, pp. 31-137.

Wagner, R.H. 2001a. The extrabasinal elements in lower Pennsylvanian floras of the Maritime Provinces, Canada: description of Adiantites, Pseudadiantites and Rhacopteridium. Revista Española de Paleontología, 16 (2), pp. 187-207.

Wagner, R.H. 2001b. Fósiles vegetales. In Recursos Naturales de Córdoba, 6, pp. 1-105. Departamento de Medio Ambiente y Protección Civil, Diputación de Córdoba.

Wagner, R.H. 2005a. Dicranophyllum glabrum (Dawson) Stopes, an unusual element of lower Westphalian floras in Atlantic Canada. Revista Española de Paleontología, 20 (1), pp. 7-13.

Wagner, R.H. 2005b. Alethopteris lancifolia Wagner, a rare element of lower Westphalian "Fern Ledges" of Atlantic Canada. Revista Española de Paleontología, 20 (1), pp. 15-19.

Wagner, R.H. 2008. Laveineopteris polymorpha from the lower Westphalian (Langsettian) "Fern Ledges" at Saint John, New Brunswick, Canada, and comparison with Laveineopteris hollandica from Europe. Revista Española de Paleontología, 23 (2), pp. 139-156.

Wagner, R.H. \& Álvarez-Vázquez, C. 2008. A revision of the lower Pennsylvanian Alethopteris lonchitica (auctorum) and its identity with Alethopteris urophylla. Revista Española de Paleontología, 23 (2), pp. 157-192.

Wagner, R.H. and Álvarez-Vázquez, C. 2010. The Carboniferous floras of the Iberian Peninsula: A synthesis with geological connotations. Review of Palaeobotany and Palynology, 162 (3), pp. 238-324. https://doi.org/10.1016/j. 
revpalbo.2010.06.005

Wagner, R.H. and Álvarez-Vázquez, C. 2016. A reappraisal of Pecopteris miltonii (Artis) Brongniart, a mid-Westphalian (Early-Mid Pennsylvanian) fern. Proceedings of the Yorkshire Geological Society, 61, pp. 37-53. https://doi. org/10.1144/pygs2015-368

Wagner, R.H. and Lemos de Sousa, M.J. 1983. The Carboniferous megafloras of Portugal - a revision of identifications and discussion of stratigraphic ages. In The Carboniferous of Portugal. Edited by M.J. Lemos de Sousa and J.T. Oliveira. Mémorias dos Serviços Geológicos de Portugal, Lisboa, 29, pp. 127-152.

Weiss, C.E. 1884. Beiträge zur fossilen Flora. III. Steinkohlen-Calamarien. II. Königlich Preussischen geologischen Landesanstalt, V (2). Text: pp. 87-290; Atlas: IXXVIII.

White, D. 1899. Fossil flora of the Lower Coal Measures of Missouri. United States Geological Survey, Monographs, XXXVII, pp. 1-467.

White, D. 1900. The stratigraphic succession of the fossil floras of the Pottsville Formation in the Southern Anthracite coal field, Pennsylvania. U.S. Geological Survey, $20^{\text {th }}$ Annual Report, 2, pp. 755-918.

Wittry, J. 2006. The Mazon Creek fossil flora. Earth Science Club of Northern Illinois, Esconi Associates, Illinois, pp. 1-154.

Zeiller, R. 1879. Végétaux fossiles du terrain houiller de la France. Explication de la Carte Géologique detaillée de la France, Tome Quatrième, Seconde Partie, pp. 1-185.

Zeiller, R. 1883. Fructifications de fougères du terrain houiller. Annales Sciences naturelles, Paris, Botanique, 6e série, XVII, pp. 130-143.

Zeiller, R. 1884. Note sur la flore et sur le niveau relatif des couches houillères de la Grand'Combe (Gard). Bulletin de la Société Géologique de France, (3), XIII, pp. 131-149.

Zeiller, R. 1886-1888. Bassin Houiller de Valenciennes. Description de la flore fossile. Études des Gîtes mineraux de la France. Texte (1888): pp. 1-729. Atlas (1886): pls I-XCIV.

Zeiller, R. 1899-1901. Etude sur la flore fossile du Bassin houiller d'Héraclée (Asie Mineure). Mémoires Société géologique de France, Paléontologie, 21, pp. 1-91.

Zeiller, R. 1907. Sur la flore et sur les niveaux relatifs des sondages houillers de Meurthe-et-Moselle. Comptes rendus de l'Académie des Sciences, Paris, 144, pp. 1137-1143.

Zimmermann, W. 1930. Die Phylogenie der Pflanzen, ein Überblick über Tatsachen und Probleme. Gustav Fischer, Jena, 454 p.

Zimmermann, W. 1959. Die Phylogenie der Pflanzen, ein Überblick über Tatsachen und Probleme. Gustav Fischer, Stuttgart, $777 \mathrm{p}$.

Zodrow, E.L. and McCandlish, K. 1980. Upper Carboniferous fossil flora of Nova Scotia in the collections of the Nova Scotia Museum, with special reference to the Sydney Coalfield. The Nova Scotia Museum, Halifax, 275 p.

\section{APPENDIX}

\section{List of names of generic or lower rank of taxa cited herein, with authorships.}

Adiantites adiantoides (Lindley and Hutton 1834) Kidston 1923

Alethopteris Sternberg 1825

Alethopteris urophylla (Brongniart 1834) Göppert 1836

Alloiopteris Potonié 1897

Alloiopteris angustissima (Sternberg 1825) Potonié 1897

Alloiopteris almaensis Bell 1944

Alloiopteris coralloides (Gutbier 1835) Zeiller 1888

Alloiopteris coralloides forma compacta Gothan 1935

Alloiopteris erosa (Gutbier 1843) White 1899

Alloiopteris georgiana (Lesquereux 1884) White 1900

Alloiopteris junghannii Gothan 1913

Alloiopteris pecopteroides Gothan 1913

Alloiopteris quercifolia (Göppert 1836) Potonié 1899

Alloiopteris sternbergii (Ettingshausen 1854) Potonié 1896

Alloiopteris winslowii White 1899

Annularia Sternberg 1821

Annularia ramosa Weiss 1884

Aspidites glockeri Göppert 1836

Aspidites silesiacus Göppert 1836

Asplenites lindsaeoides Ettingshausen 1854

Asplenites sternbergii Ettingshausen 1854

Asterophyllites Brongniart 1822

Asterophyllites grandis (Sternberg 1825) Geinitz 1855

Asterotheca Presl in Corda 1845

Asterotheca arborescens (Schlotheim 1804 ex Brongniart 1828a) Stur 1877

Asterotheca inferior Stockmans and Willière 1966

Asterotheca praecursor Stockmans and Willière 1966

Bertrandia Dalinval 1960

Bertrandia avoldensis (Stur 1883) Dalinval 1960

Boweria Kidston 1911

Boweria minor Kidston 1923

Boweria schatzlarensis Kidston 1911

Boweria nowarudensis Frojdová et al. 2017b

Calamites Suckow 1784

Calamites carinatus Sternberg 1824

Calamites suckowii Brongniart 1828a

Callipteris Brongniart 1849

Callipteris pilosa (Dawson 1868) Dawson 1871

Calymmotheca Stur 1877

Calymmotheca avoldensis Stur 1883

Calymmotheca frenzli Stur 1883

Calymmatotheca Zeiller 1883

Cordaites Unger 1850

Cordaites principalis (Germar 1848) Geinitz 1855

Corynepteris Baily 1860

Corynepteris angustissima (Sternberg 1823) Němejc 1938

Corynepteris coralloides var. compacta Danzé 1956

Corynepteris stellata Baily 1860

Corynepteris sternbergii (Ettingshausen 1854) Zeiller 1899

Corynepteris winslovii White 1899 
Crossotheca Zeiller 1883

Crossotheca boulayi Zeiller 1888

Crossotheca bourozi Danzé 1956

Crossotheca compacta Bell 1938

Crossotheca crepinii Zeiller 1883

Crossotheca kidstonii Hemingway ex Crookall 1930

Crossotheca schatzlarensis (Stur 1883) Kidston 1888

Cyperites Lindley and Hutton 1832

Dactylotheca plumosa (Artis 1825) Kidston 1886

Dactylotheca plumosa forma dentata Bell 1938

Dicksonites plukenetii (Schlotheim ex Sternberg 1825) Sterzel 1881

Diplotmema furcatum (Brongniart 1829) Stur 1877

Diplotmema sancti-felicis Stur 1885

Discopteris Stur 1883

Discopteris karwinensis Stur 1883

Discopteris vuellersii Stur 1883

Dorycordaites palmaeformis (Göppert 1852) Grand'Eury 1877

Eusphenopteris pulchrior (Gothan and Jongmans 1915) Amerom 1975

Eusphenopteris sauveurii (Crépin 1880) Simson-Scharold 1934

Filicites plumosus Artis 1825

Germera Brousmiche 1983

Germera brousmicheae sp. nov.

Germera mendescorreae (Teixeira 1939) Brousmiche 1983

Grand'Eurya Zeiller 1883

Hapalopteris Stur 1883

Hapalopteris amoena Stur 1885

Hapalopteris bella Stur 1885

Hapalopteris aschenborni Stur 1885

Hapalopteris microscopica Crépin ex Stur 1885

Hapalopteris schatzlarensis Stur 1885

Hapalopteris typica Stur 1883

Heteropteris Potonié 1893

Hymenophyllites curtilobus Dawson 1862

Hymenotheca dathei Potonié 1890

Karinopteris obtusifolia (Gothan 1941) Álvarez-Vázquez 1995

Kidstoniopteris Frojdová et al. 2017b

Kidstoniopteris minor (Kidston 1923) Frojdová et al. 2017b

Laveineopteris polymorpha (Dawson 1862) Wagner 2008

Lepidostrobophyllum Hirmer 1927

Lyginopteris hoeninghausii (Brongniart 1830) Gothan 1931

Neuropteris serrulata Dawson 1862

Oligocarpia Göppert 1841

Oligocarpia brongniartii Stur 1883

Oligocarpia gutbieri Göppert 1841

Oligocarpia mixta (Schimper 1869) Abbott 1954

Oligocarpia splendens (Dawson 1871) Stopes 1914

Oligocarpia stipulataeformis Stur 1885

Palmatopteris Potonié 1892

Palmatopteris alata (Brongniart 1830) Potonié 1892

Palmatopteris furcata (Brongniart 1829) Potonié 1892

Paripteris Gothan 1941

Pecopteris Brongniart 1828a
Pecopteris alloiophylla Doubinger and Germer 1971

Pecopteris angustifida Ettingshausen 1854

Pecopteris angustissima Sternberg 1823

Pecopteris avoldensis (Stur 1883) Corsin 1932

Pecopteris brachyphylla Doubinger and Germer 1971

Pecopteris chaerophylloides Brongniart 1836

Pecopteris clarkii Lesquereux 1880

Pecopteris delicatula Brongniart 1836

Pecopteris densifolia Dawson 1871

Pecopteris dentata Brongniart 1836

Pecopteris engyphylla Doubinger and Germer 1971

Pecopteris georgiana Lesquereux 1884

Pecopteris glockeriana Presl in Sternberg 1838

Pecopteris micromiltonii Bertrand ex Corsin 1951

Pecopteris miltonii (Artis 1825) Brongniart 1828a

Pecopteris mucronata Presl in Sternberg 1838

Pecopteris pachyneura Doubinger and Germer 1971

Pecopteris pennaeformis Brongniart 1828a

Pecopteris pilosa (Dawson 1868) Bell 1944

Pecopteris plumosa (Artis 1825) Brongniart 1832

Pecopteris plumosa var. dentata Sterzel 1901

Pecopteris plumosa forma crenata Bell 1944

Pecopteris preciosa Hartt in Dawson 1868

Pecopteris pseudovestita White 1899

Pecopteris pycnoneura Doubinger and Germer 1971

Pecopteris serra Lindley and Hutton 1834

Pecopteris serrulata (Dawson 1862) Dawson 1868

Pecopteris silesiaca Göppert 1845

Pecopteris tenuinervosa Corsin 1951

Renaultia Zeiller 1883

Renaultia chaerophylloides (Brongniart 1836) Zeiller 1883

Renaultia crepinii (Stur 1885) Zeiller 1899

Renaultia footneri (Marrat 1872) Kidston 1893

Renaultia gracilis (Brongniart 1828a) Zeiller 1883

Renaultia hemingwayi Kidston 1923

Renaultia hydei Bell 1944

Renaultia rotundifolia (Andrae 1869) Zeiller 1899

Renaultia schatzlarensis (Stur 1885) Kidston 1890

Rhodea Presl in Sternberg 1838

Rhodea laqueata Bell 1944

Rhodea sparsa Kidston 1923

Rhodea stachei Stur 1877

Rhodeopteridium Zimmermann 1959

Saccopteris Stur 1883

Samaropsis Göppert 1864

Senftenbergia Corda 1845

Senftenbergia aspera (Brongniart 1828a) Stur 1877

Senftenbergia pennaeformis (Brongniart 1828a) Stur 1877

Senftenbergia plumosa (Artis 1825) Stur 1877

Sorotheca Stur 1883

Sphenophyllum cuneifolium (Sternberg 1823) Zeiller 1879

Sphenopteris (Brongniart 1822) Brongniart 1828a

Sphenopteris aculeata Bell 1838

Sphenopteris alata Brongniart 1830

Sphenopteris amoenaeformis Kidston 1923

Sphenopteris bella (Stur 1885) Zeiller 1899

Sphenopteris boehnischii (Stur 1883) Šusta 1928 
Sphenopteris boulayi Zeiller 1886

Sphenopteris bronnii Gutbier 1835

Sphenopteris cantiana Kidston 1923

Sphenopteris caudata Lindley and Hutton 1832

Sphenopteris coralloides Gutbier 1835

Sphenopteris crenata Lindley and Hutton 1834

Sphenopteris crepinii Zeiller 1883

Sphenopteris cuneoliformis Bell 1944

Sphenopteris delicatula Sternberg 1825

Sphenopteris deltiformis Kidston 1914

Sphenopteris digitata Doubinger 1959

Sphenopteris dixonii Kidston 1917

Sphenopteris effusa Kidston 1886

Sphenopteris essinghii Andrae 1866

Sphenopteris fletcheri Bell 1944

Sphenopteris footneri Marrat in Higgins 1872

Sphenopteris gracilis (Brongniart 1828a) Zeiller 1888

Sphenopteris harttii Dawson 1862

Sphenopteris hoeninghausii Brongniart 1828a

Sphenopteris hymenophylloides (Kidston 1923) Gothan 1941

Sphenopteris laciniosa Âlvarez Ramis et al. 1978

Sphenopteris laurenti Andrae 1865

Sphenopteris marginata Dawson 1862

Sphenopteris mendescorreae Teixeira 1939

Sphenopteris microcyclos Gothan 1941

Sphenopteris mixta Schimper 1869

Sphenopteris moyseyi Kidston 1923

Sphenopteris parviloba Danzé 1956

Sphenopteris philipensis Bell 1944

Sphenopteris pilosa Dawson 1868

Sphenopteris quadriloba Kidston 1923

Sphenopteris rotundifolia Andrae 1869
Sphenopteris rutaefolia Gutbier 1835

Sphenopteris sampaiana Teixeira 1939

Sphenopteris sancti-felicis (Stur 1885) Rydzewski 1913

Sphenopteris schatzlarensis (Stur 1885) Zeiller 1899

Sphenopteris schilleri Gothan 1913

Sphenopteris schwerinii (Stur 1885) Zeiller 1899

Sphenopteris souichii Zeiller 1888

Sphenopteris splendens Dawson 1871

Sphenopteris stipulataeformis (Stur 1885) Gothan 1913

Sphenopteris philipensis Bell 1944

Sphenopteris pilosa Dawson 1868

Sphyropteris Stur 1883

Sphyropteris boehnischii Stur 1883

Sphyropteris crepinii Stur 1883

Sphyropteris frankiana Gothan 1912

Sphyropteris obliqua (Marrat 1872) Kidston 1889

Sphyropteris tomentosa Stur 1883

Stigmaria ficoides (Sternberg 1820) Brongniart 1822

Sturia Němejc 1934

Sturia amoena (Stur 1885) Němejc 1934

Urnatopteris herbacea (Boulay 1876) Carpentier 1919

Zeilleria Kidston 1884

Zeilleria avoldensis (Stur 1883) Kidston 1884

Zeilleria delicatula Kidston 1884

Zeilleria frenzlii (Stur 1883) Kidston 1884

Zeilleria hymenophylloides Kidston 1924

Zeilleria lignyi Stockmans and Willière 1958

Zeilleria pilosa (Dawson 1868) Wagner 2001b

Zeilleria schaumburg-lippeana (Stur 1885) Zeiller 1907

Zeilleria stellata Arnold 1937

Editorial responsibility: Robert A. Fensome 